ENCUESTA 



\title{
ENCUESTA SOBRE EL TRIBUNAL EUROPEO DE DERECHOS HUMANOS
}

\author{
PRESENTACIÓN
}

Nuestros lectores recordarán que dedicamos en 2017 nuestro número 39, con carácter monográfico, al «TJUE como actor de constitucionalidad». Y de la excelente acogida de sus páginas por nuestros colegas es hijo natural el presente número, que dedicamos al TEDH.

Porque sabido es que la globalización en que nos encontramos inmersos conlleva una creciente internacionalización de las relaciones económicas, sociales, políticas, jurídicas... con notoria emergencia de espacios supranacionales, que incluyen el ámbito de los derechos. Y que en este contexto de internacionalización de las relaciones humanas asistimos a una cierta búsqueda de un soberano supranacional que permita al constitucionalismo de los estados democráticos admitir que los derechos de sus respectivos ciudadanos deben ser básicamente los mismos; y a esto respondió en su día el gran paso que supuso el Convenio Europeo de Derechos Humanos, creando una suerte de aquis communitaire en su materia.

La conversión, como analizamos en el pasado número monográfico al que aludíamos anteriormente, de las antiguas Comunidades Europeas a la actual Unión Europea, y así, de un Tribunal de Justicia de las Comunidades Europeas, motor de cierta integración económica, a un Tribunal de Justicia de la Unión Europea, verdadero actor de la constitucionalidad en Europa, ha supuesto un hito fundamental en el reto anteriormente planteado. La Carta ha superado la concepción meramente «comunitaria» del Derecho de la Unión, que, tras ella es ya una comunidad de derechos patrimonio de la persona; si bien no puede superar plenamente la dicotomía de que la Unión es aún, sobre todo, una comunidad económica con competencias tasadas, sí cabe constar, a la par, que es un Ordenamiento jurídico al servicio de la defensa de los derechos de las personas, lo que implica el deber de su protección, que desplaza la voluntad estatal por la prevalencia del Derecho de la Unión.

El Convenio Europeo de Derechos Humanos, que ha permeado la labor jurisprudencial del Tribunal de Estrasburgo en su materia, ha encontrado un aldabonazo en las posibilidades de relación con el Tribunal de Justicia de la Unión Europea, que precisamente tras Niza y tras la aprobación de la Carta de Derechos Fundamentales de la Unión Europea, ha adquirido esta dimensión superior. La Carta de Derechos de la Unión Europea, como sabemos, revisada en 2007 poco antes de la firma del Tratado de Lisboa — que la hace vinculante- crea un espacio supranacional de protección de derechos de la mayor importancia, que junto con el espacio ya generado por el 
Convenio europeo de Derechos Humanos, bien puede contribuir a generar este soberano supranacional que permita extender la garantía de los derechos también a nivel internacional.

Ahora bien, el aquis communitariae que ha creado ya Tribunal Europeo de Derechos Humanos, aplicando e interpretando un Convenio, durante un tiempo no menor, ha permitido situar a este tribunal en una posición ciertamente relevante. Que se evidencia en una particular forma de concebir e interpretar los derechos en los diferentes órdenes constitucionales de los Estados miembros del Consejo de Europa, algo que ha penetrado en los diferentes Tribunales Constitucionales de tales Estados. De hecho, la jurisprudencia de nuestro Tribunal Constitucional se apoya, con cada vez más frecuencia, en la doctrina del Tribunal Europeo de Derechos Humanos respecto de los derechos del convenio. Y así, la propia jurisprudencia de este tribunal, en la que muestra una particular forma de interpretar y aplicar los derechos, puede ser un modelo, ya no sólo para los tribunales constitucionales de los estados miembros, sino para el propio Tribunal de Justicia de la Unión Europea. En las relaciones entre estos tribunales, Tribunal Europeo de Derechos Humanos, tribunales constitucionales de los Estados miembros y Tribunal Europeo de Derechos Humanos, no podemos ignorar la experiencia y el arraigo de la jurisprudencia de este último tribunal.

En cualquier caso, no podemos ocultar que tanto la esencia y naturaleza jurídica de este tribunal, como la jurisprudencia que de él emana — según es consustancial a las categorías jurídicas - no están exentas de polémicas académicas, cuyos reflejos prácticos no son ignorables. Así sucede, por ejemplo, con conceptos como el de interpretación dinámica o evolutiva del tribunal, o el denominado margen de apreciación nacional, sobre los que hay interesantes debates abiertos, en que los constitucionalistas han de ser oídos pues desde nuestra ladera debemos hacer aportaciones útiles para establecer su debido alcance. Y otro tanto, según creemos, cabe decir de las denominadas sentencias piloto en que el tribunal hace uso de recomendaciones al Estado, a los efectos de postular el cambio de aquellas regulaciones que pudieran ser eventualmente incompatibles con principios del convenio.

Así mismo, el TEDH ha desarrollado importantes tesis jurisprudenciales en torno a grupos de derechos particularmente significativos, como en el caso de la libertad de expresión y los límites de tal libertad, o en el del derecho de participación política y las posibilidades de prohibición de partidos políticos. Estamos ante construcciones doctrinales interesantísimas para el avance de nuestra ciencia jurídico constitucional, pero que lejos de pertenecer al ámbito de las ciencias exactas, son objeto tanto de alabanzas, como de ciertos cuestionamientos.

Consiguientemente estamos ante una nueva dinámica de avance en la protección efectiva de los derechos humanos de quienes convivimos en la órbita del TEDH, que Teoría y Realidad Constitucional considera terreno propio de un fino debate dialéctico en el seno de esta encuesta que sirve de pórtico al presente número monográfico. A tal fin, hemos convocado a prestigiosos constitucionalistas, para que para que puedan tomar como excusa las preguntas que formulamos y, con la mayor libertad, nos aporten su docta visión de la naturaleza de este importante tribunal y de la relevante jurisprudencia que ha emitido hasta la fecha. Nos agradaría que nuestros agudos lectores concluyan que esta encuesta y el conjunto del presente número monográfico contribuyen modestamente a avanzar algunos pasos en la construcción de una doctrina certera y útil 
para una defensa cada vez más efectiva de los derechos inviolables de la persona, fundamento del orden político y de la paz social. Por lo demás, es de justicia señalar el agradecimiento del Consejo de Redacción a los Profesores Luis López Guerra y Javier García Roca por sus interesantes y sugerentes aportaciones en las reuniones preparatorias del número como destacados expertos en la materia.

\section{CUESTIONES}

1. ¿Podría exponernos, a modo de introducción, el juicio que le merece la posición adoptada por el TEDH desde su creación hasta la relevancia que su jurisprudencia ha alcanzado en nuestros días?

2. ¿Nos puede facilitar su opinión acerca de si el eventual conflicto entre una Ley y un Tratado Internacional debe ser resuelto directamente por el Juez nacional, o si este debe plantear la denominada Cuestión de Convencionalidad?

3. ¿Qué querría decirnos sobre la interpretación dinámica o evolutiva del TEDH? ¿Cómo valora tal jurisprudencia? ¿Puede, en su opinión, ser compatible con la seguridad jurídica y con los limites en la actividad interpretativa y aplicativa de los jueces?

4. ¿Cómo valora el que la jurisprudencia del TEDH respete el llamado margen de apreciación nacional? ¿Y su compatibilidad con otros valores básicos del orden constitucional, como el de seguridad jurídica?

5. ¿Cuál es su opinión sobre las recomendaciones del TEDH a los Estados? ¿Y sobre las sentencias piloto?

6. Como es sabido, en la creación del espacio europeo de protección de derechos, el TEDH ha desarrollado una especial jurisprudencia protectora de la libertad de expresión. ¿Cómo valora tal jurisprudencia? ¿Quiere añadir algo sobre la ponderación que realiza el Tribunal de esa libertad fundamental con la probibición de los denominados delitos de odio?

\section{ENCUESTADOS}

ENOCH ALBERTÍ ROVIRA, Catedrático de Derecho Constitucional, Universidad de Barcelona

JUAN MARÍA BILBAO UBILLOS, Catedrático de Derecho Constitucional, Universidad de Valladolid

VÍCTOR FERRERES COMELLA, Catedrático de Derecho Constitucional, Universidad Pompeu Fabra

JAVIER GARCÍA ROCA, Catedrático de Derecho Constitucional, Universidad Complutense de Madrid

LUIS JIMENA QUESADA, Catedrático de Derecho Constitucional, Universidad de Valencia

CARLOS RUIZ MIGUEL, Catedrático de Derecho Constitucional, Universidad de Santiago de Compostela

ROSARIO TUR AUSINA, Catedrática de Derecho Constitucional, Universidad, Miguel Hernández 


\section{RESPUESTAS}

1. ¿Podría exponernos, a modo de introducción, el juicio que le merece la posición adoptada por el TEDH desde su creación hasta la relevancia que su jurisprudencia ba alcanzado en nuestros días?

\section{ENOCH ALBERTÍ ROVIRA}

No cabe ninguna duda de que el mecanismo de protección de derechos establecido por el Convenio de Roma ha tenido y tiene una importancia extraordinaria en la creación, extensión y consolidación de un espacio europeo de derechos fundamentales, base de un orden público europeo. Este proyecto es imperfecto y presenta problemas e incertidumbres, sin ninguna duda tampoco. Pero no cabe negar en absoluto que constituye un gran avance, de dimensión histórica, y ello tanto desde una perspectiva general —el espacio europeo en su conjunto- como también, en la mayor parte de los casos, desde la de los diversos estados parte. El acceso individual de las personas a un instrumento jurisdiccional de protección de los derechos de carácter internacional, constituye un hito fundamental del desarrollo de los derechos e incluso del propio derecho internacional. Con independencia de las valoraciones, el hecho cierto es que un amplio número de Estados ha consentido en ser controlado por sus propios ciudadanos a través de una instancia jurisdiccional independiente, y este hecho tiene una significación y una trascendencia realmente histórica.

También, naturalmente, se presentan numerosos problemas, algunos debidos a la naturaleza internacional del mecanismo establecido y las limitaciones intrínsecas que comporta (en relación al ámbito y la forma del control, la eficacia de sus sentencias, o el carácter de protección mínima y su relación con los ordenamientos internos y sus respectivas jurisdicciones) y otros a la extensión de su ámbito de aplicación (800 millones de personas en 47 Estados) y a la enorme heterogeneidad de los Estados que forman parte del mismo. El Consejo de Europa, y el propio TEDH, han tenido que afrontar nuevas situaciones y retos, no solo para sobrevivir sino también para seguir evolucionando y poder acomodarse a los nuevos tiempos y circunstancias, con mayores exigencias de protección de los derechos y nuevas y más sofisticadas formas de vulneración potencial de los mismos. Algunos de estos problemas se abordan precisamente con ocasión de las preguntas que siguen.

\section{JUAN MARÍA BILBAO UBILLOS}

De entrada, hemos de congratularnos por el creciente protagonismo de este tribunal supranacional, que se inscribe en el contexto de un fenómeno más amplio, el de la internacionalización de los derechos humanos (ya no son un asunto interno). Estamos, por tanto, ante un nuevo escenario marcado por la tutela multinivel de los derechos y el diálogo entre tribunales, que se salda con un recíproco enriquecimiento o fecundo intercambio (cross-fertilization). Además, el balance de estos casi 60 años de rica jurisprudencia en torno a los derechos civiles y políticos del Convenio es muy positivo. Pocos podían 
imaginar en 1959, cuando se pone en marcha, que la doctrina acuñada por el Tribunal sobre esos derechos (y los incorporados en los sucesivos Protocolos, como el derecho de propiedad, el derecho a la educación, la garantía de unas elecciones libres — de la que el Tribunal ha extraído el derecho individual al sufragio — o las garantías procesales en caso de expulsión de los extranjeros) terminaría por vincular a los operadores jurídicos de 47 países, con una población de 800 millones de personas (de potenciales demandantes), adquiriendo así una dimensión paneuropea. Un efecto de irradiación que va mucho más allá del formal acatamiento de sus decisiones por las autoridades de los Estados que se sometieron a su jurisdicción y que vienen cumpliendo de forma leal (en la mayoría de los casos) el compromiso adquirido en su día, un aspecto no desdeñable porque la ejecución de las sentencias es responsabilidad del Estado condenado, bajo la atenta supervisión del Comité de Ministros.

Pero esa influencia no se mide sólo en términos cuantitativos (21.000 sentencias dictadas desde su creación, conjurando el riesgo de colapso — se puede morir de éxitomediante sucesivas reformas que han agilizado el procedimiento) o espaciales. Como intérprete autorizado del Convenio y sus Protocolos, el Tribunal se ha ganado a pulso un merecido prestigio. Es una institución respetada, que ha dado pruebas de firmeza en la defensa de las libertades, sin ceder a las presiones de los Estados. Y que ha contribuido a la construcción dogmática de los derechos con aportaciones tan valiosas como el test de proporcionalidad que aplica de forma sistemática a la hora de decidir si una determinada restricción está o no justificada, o las obligaciones positivas de protección que se derivan del reconocimiento de los derechos en el Convenio. Su doctrina ha ido reflejando en cada momento el consenso existente en Europa sobre la forma de concebir y proteger los derechos fundamentales, asumiendo en algunos casos un claro liderazgo. La Europa de los derechos es hoy una realidad tangible. Con su jurisprudencia, ha hecho del Convenio un instrumento vivo, ampliando progresivamente el contenido y alcance de los derechos garantizados.

En nuestro país, el acervo jurisprudencial elaborado por el Tribunal de Estrasburgo ha sido y sigue siendo, por imperativo constitucional (art. 10.2 CE), una referencia inexcusable a la hora de interpretar nuestra declaración de derechos. Al fin y al cabo, es el órgano que tiene la última palabra en materia de libertades (efecto de «cosa interpretada»). Cuando nos sometimos a su jurisdicción renunciamos en cierto modo a la autonomía de nuestros tribunales a la hora de interpretar nuestros derechos.

El impacto de la jurisprudencia de Estrasburgo es bien patente: son decenas de miles las resoluciones de jueces y tribunales de todos los órdenes jurisdiccionales que apelan a esa jurisprudencia como canon hermenéutico «de decisiva relevancia» (STC 22/1981). Es una difusión capilar, pero destaca sobre todo la receptividad de nuestro Tribunal Constitucional, que ha recurrido a la misma de forma constante a la hora de perfilar el contenido de los derechos reconocidos en sede constitucional. Son muchas, en efecto, las sentencias que siguen la pauta marcada por el TEDH y se inspiran expresamente en su doctrina. Entre otras razones, porque no se quiere correr el riesgo de una condena por parte del TEDH. Esa vinculación se refleja también en la STC 155/2009, que menciona expresamente entre los supuestos en los que se presume que el recurso de amparo tiene especial trascendencia constitucional el de «un cambio en la doctrina de los órganos de garantía encargados de la interpretación de los tratados y acuerdos internacionales a los que se refiere el art. 10.2 CE». 
Esa sintonía, que ha sido la tónica dominante en estos 38 años de coexistencia, no se ha visto empañada por la existencia de alguna divergencia puntual, como las reticencias manifestadas a la hora de incluir en el ámbito del art. $18 \mathrm{CE}$, que no consagra un macro-derecho a la vida privada, sino varios derechos autónomos (a la intimidad, a la inviolabilidad de domicilio y al secreto de las comunicaciones), la tutela frente a la contaminación acústica. Otra cosa es la actitud del legislador, que no siempre se ha mostrado tan diligente a la hora de ajustar nuestro ordenamiento positivo a las directrices establecidas por el Tribunal de Estrasburgo. Basta recordar en este sentido, su pasividad en relación con la regulación de las garantías que deben reunir las decisiones judiciales en materia de intervención y grabación de las comunicaciones o la reforma del recurso de revisión para hacer posible la ejecución de las sentencias condenatorias del TEDH, asignaturas pendientes durante muchos años (hasta el 2015 en ambos casos).

\section{VÍCTOR FERRERES COMELLA}

El TEDH se ha transformado de manera notable a lo largo de los años. En el momento fundacional, el Tribunal tenía por misión principal la de velar por el respeto a las exigencias más básicas vinculadas a los derechos humanos. El control que se esperaba del Tribunal era un control de mínimos: asegurar la observancia del núcleo indiscutible de los derechos. Por esta razón, la jurisprudencia del Tribunal no tenía una incidencia muy significativa en la configuración legal de los derechos a escala nacional. La tensión con el principio democrático era, por ello, apenas perceptible. En la actualidad, en cambio, el Tribunal desempeña un papel muy relevante en el discurso de los derechos. Los casos de los que conoce son con frecuencia muy controvertidos, y le colocan en la posición de vanguardia en materia de derechos. No es sorprendente que las decisiones de Estrasburgo hayan suscitado polémicas, y que en los últimos tiempos se haya problematizado la conformidad de la jurisdicción del Tribunal con el principio democrático.

\section{JAVIER GARCÍA ROCA}

La evolución del sistema del Convenio Europeo de Derechos Humanos (CEDH) producida por la jurisprudencia del Tribunal Europeo de Derechos Humanos (TEDH) me parece muy positiva ${ }^{1}$. Esta protección colectiva, tras casi siete décadas de experiencias y pronunciamientos, ha creado un ius commune europeo sobre derechos fundamentales, sin perjuicio del Derecho propio de los Estados miembros y también ha contribuido a su mejor garantía, de manera más real y efectiva, y tanto en su protección internacional como interna; igualmente ha desarrollado unos estándares convencionales comunes que armonizan la interpretación de los derechos en un espacio de más de ochocientos millones de personas y cuarenta y siete Estados. Todo ello ha edificado una «Europa de los derechos», unas sociedades más tolerantes, ilustradas y abiertas de mentes, y ha

1 Puede leerse «La transformación del Convenio Europeo de Derechos Humanos» en Revista General de Derecho Constitucional, de próxima edición, algunas de cuyas tesis sintetizo y donde se dan noticia de otros trabajos propios y colectivos del equipo de investigación que coordino y que hace veinte años creamos con Pablo Santolaya. 
favorecido la integración europea a través de derechos y no sólo mediante la unión económica, presupuestaria y monetaria que impulsa la Unión. El sistema del Convenio es una forma lenta y progresiva, pero irrefrenable, de crear un demos europeo, una patria fundada en la cultura europea, y confieso que me siento un joven activista de esta causa. El Convenio y el Tribunal son la joya del Consejo de Europa: su fruto más exitoso. ¿Qué más puede pedirse?

Pero, como todo logro humano, el sistema es susceptible de mejora y debe continuar evolucionando para afrontar los nuevos desafíos. Sobre todo, la sobrecarga de asuntos pendientes de enjuiciamiento (56.250 demandas en 2017) en virtud del desbordamiento que produce el direct access y una legitimación activa tan difusa, que no ha solventado la mejor organización de la inadmisión de los asuntos que ha permitido el Protocolo 14 al no bajar la demanda de tutela. También divulgar el entendimiento de los derechos y los métodos de trabajo del TEDH entre jueces y abogados en los Estados miembros, según recomendaron el Informe de Lord Woolf y el Informe de los expertos (wise persons'report), para generar los beneficios de una cultura preventiva antes que judicial y represiva. La puesta en marcha de las nuevas «opiniones consultivas» que crea el Protocolo 16 y acaban de entrar en vigor, unas verdaderas cuestiones de inconvencionalidad cuyo funcionamiento me suscita esperanza; no en balde muchos estimamos que el mejor proceso que la justicia constitucional europea ha creado es la cuestión de inconstitucionalidad. Los diversos problemas detectados en la ejecución de las sentencias y en la supervisión de las mismas, comenzando por los pockets of resistance y la eficacia de los planes de actuación. Afrontar con realismo y sabia paciencia, pero sin merma de garantismo, los daños que generan los emergentes populismos aparecidos con la Gran Recesión en varios países como Polonia, Hungría, pero también en el Reino Unido durante la irresponsable presidencia nacionalista del Sr. Cameron quien hizo — absurdamente- de la saga Hirst y de la resistencia a su implementación un Brexit antes del Brexit; también la problemática situación autoritaria en Rusia; o el reciente entendimiento radical del islamismo en Turquía que amenaza con acabar con los logros impulsados durante lustros en ese país con una paciente jurisprudencia europea. El Consejo de Europa debe colaborar asimismo con los Estados en solventar los defectos estructurales en la protección de los derechos en los países habitualmente más condenados (Rusia, Ucrania, Turquía, Rumanía, Hungría) que se llevan la parte del león (un 63,6 por ciento en 2017) en el stock de las demandas. Finalmente, pero no en importancia, es menester mantener el consentimiento de los Estados en la jurisdicción europea, respetando un cierto margen de apreciación nacional donde resulte inevitable, para no generar más problemas que los que pueden razonablemente resolverse a distancia.

¿Cómo sintetizar el trabajo de casi siete décadas? En el estudio que ya he citado he subrayado media docena de líneas de transformación impulsadas por el TEDH. La primera consiste en que desde los orígenes, la aprobación del Convenio en Roma en 1950 en un contexto bipolar de guerra fría, ha habido una constante expansión de la jurisdicción europea. El Consejo de Europa ha pasado de ser un pequeño club de democracias estables — según lo calificó Carrillo Salcedo_- a un amplio espacio, mucho más amplio y plural en Estados miembros con su apertura hacia el Este. La caída del muro de Berlín en 1989 supuso cambios culturales importantes. La labor de las instituciones del Consejo de Europa y, en particular, del TEDH ha sido muy importante en el impulso de las transiciones en los antiguos países comunistas. Han aparecido en la jurisprudencia violaciones 
de algunos derechos absolutos o muy básicos como son las series de decisiones sobre muertes, torturas y desaparecidos en Chechenia y en el Kurdistán, o el penoso estado de las cárceles hasta suponer malos tratos, sobre todo, en los países del Este.

Pese a esta expansión, o muy probablemente por ella, el sistema de protección de los derechos sigue siendo binario, Unión/Consejo de Europa, merced al veto a la adhesión de la Unión Europea al CEDH que produjo el formalista Dictamen 2/13 del Tribunal de Justicia de 18 de diciembre de 2014. Me he pronunciado críticamente en varias ocasiones sobre este dictamen. Una decisión que no solucionó problema alguno y por el contrario creo muchos, carente de la empatía que demanda un sistema de pluralismo constitucional en Europa. Otra respuesta era posible como ilustra la posición de la Abogada General. Veremos cómo culmina este asunto tras esta «grave decepción» en palabras del entonces Presidente del TEDH, Dean Spielmann.

La expansión de la jurisdicción en su ámbito personal y territorial y la desaparición del filtro que entrañaba la Comisión en 1998 gracias al Protocolo 11 ha producido un crecimiento exponencial de los asuntos. Hubo todavía 63.350 demandas en 2017. Si bien en su mayor parte son inadmitidas o canceladas (alrededor de un 92 por ciento). Si se ha dicho que el amparo constitucional es un lujo, el amparo europeo empieza a ser un remedio muy excepcional, pese a las afirmaciones más o menos retóricas del Tribunal y el Consejo en defensa del acceso directo siguiendo las recomendaciones en defensa del derecho individual de petición que hizo el Informe de los sabios o expertos. La realidad es otra y mucho más matizada: proporcionalmente pocos casos merecen ser enjuiciados por sentencia.

El Tribunal maneja con soltura sus inadmisiones y la selección de los asuntos. No obstante, poner un millar de sentencias cada año (1068 en 2017) es labor compleja y son prácticamente imposibles de leer por los operadores jurídicos. Afortunadamente, se jerarquizan de 1 a 3 o como case reports y esto ayuda a seleccionar las lecturas más importantes. Es también muy útil la mención de sus precedentes que el Tribunal hace en las fichas de cada sentencia para saber qué hay de nuevo. Pese a todas estas técnicas y a la utilidad de los press releases de jurisprudencia son demasiadas sentencias, muy largas y redactadas en inglés o francés - y no siempre dicen lo mismo- para poder ser asimiladas con facilidad por millones de destinatarios. ¿Cómo interpretar los derechos escribiendo tanto?

Creo que este océano de jurisprudencia obliga a los Tribunales Supremos y Constitucionales de cada Estado a dar un paso al frente y actuar como «mediadores» divulgando los estándares jurisprudenciales de Estrasburgo entre los jueces nacionales en un interesante diálogo judicial. Las altas cortes deben explicar a sus jueces cómo incorporar el acquis conventionnel en su decisiones, extrayendo virtualidad a la eficacia de cosa interpretada que se predica de las sentencias europeas, y a su eficacia vinculante — semejante al de las sentencias constitucionales - y valor como precedente que he teorizado en nuestra última investigación colectiva.

Por lo demás, las herramientas hermenéuticas que usa la doctrina jurisprudencial de Estrasburgo han cambiado la faz de los derechos contribuyendo a crear una teoría general de los derechos europeos. Entre su ingredientes, cuestiones decisivas como son la doctrina de las obligaciones positivas de los Estados para asegurar los derechos, v.gr. las obligaciones de procedimiento e investigación. La necesidad de una exégesis real y efectiva, material y antiformalista, pues el Convenio no protege derechos ilusorios o teoréticos. 
Unos derechos entendidos en clave de una interpretación evolutiva, pues el Convenio es un instrumento vivo de acuerdo con nowadays present conditions. La ubicación de los derechos como ingredientes del Rule of Law o Estado de Derecho lo que los engasta en un contexto garantista en leyes, decisiones y procedimientos. La consolidación de un muy estructurado juicio de proporcionalidad, sobre la legitimidad de los fines que persigue el legislador democrático y la necesidad de la medida, que se ha convertido en el principio de interpretación central en toda Europa, desplazando a la vieja ragionevolezza o razonabilidad que tanto ha usado el Tribunal Constitucional español. La consolidación - no menos importante- de un principio de legalidad de los derechos en sus vertientes tanto formal como material, que demanda la calidad de la ley y que las interferencias legales en los derechos sean previsibles y ciertas o taxativas. Sin previsión legal no hay límites válidos.

Respecto de los contenidos de los derechos que el TEDH ha ido creando mediante millares de casos siguiendo una interpretación tópica y constructiva sobre una cláusulas convencionales muy abierta y sucintas (v.gr. proceso debido, vida privada y familiar, elecciones libres y periódicas, libertad de expresión...), aún más que las constitucionales, se han convertido en un Derecho común europeo de génesis jurisprudencial. En España, como en otras democracias más recientes de los años ochenta y noventa, este Derecho común se recibió directamente en las normas constitucionales, y también al sentar las bases de nuestra jurisprudencia constitucional, que no hubiera podido construirse tan rápidamente sin recibir la herencia de Estrasburgo. Pero luego ha ido habiendo incorporaciones sobrevenidas, recibiendo el impacto transformador de la jurisprudencia europea como ha ocurrido en la defensa frente al ruido y las diversas contaminaciones. El ritmo del impacto de esta jurisprudencia ha sido diferente en cada país.

El entendimiento de esta jurisdicción, ratione temporis y ratione personae, en la jurisprudencia europea ha expandido asimismo sus confines claramente. Con distintos matices, se investigan hechos y actividades procesales acaecidas antes de la entrada en vigor en un país del Convenio. No hay límites por razón de la persona: cualquier persona sometida a la jurisdicción de un Estado miembro, aunque se encuentre fuera del territorio nacional e incluso europeo (v.gr. miembros de fuerzas armadas en misiones en el extranjero). Una circunstancia que otorga una relativa extraterritorialidad al Convenio

Los distintos Protocolos adicionales o de reforma del Convenio y las recomendaciones del Comité de Ministros han ido igualmente transformando el sistema del Convenio, normalmente robusteciendo e incrementando las facultades del TEDH de una manera que no puedo detenerme en explicar aquí. Sólo el Protocolo 15, que aún no ha entrado en vigor, hace una llamada de atención invocando el principio de subsidiariedad y el margen de apreciación nacional que pueden leerse como una demanda de autocontención o self-restraint.

La segunda línea de caracterización es que la comprensión del CEDH ha evolucionado de una protección internacional, un tratado sui generis como le llamó Drzemczeswki en los ochenta, a «un instrumento constitucional del orden público europeo» en palabras del propio TEDH. Se ha producido una fusión de las interpretaciones constitucional y convencional de los derechos, si dejamos a un lado por un momento los principios de subsidiariedad y la doctrina del margen de apreciación nacional. Los criterios de interpretación de la Convención de Viena sobre el derecho de los tratados poseen menos relevancia que otros principios más específicos de génesis constitucional a la hora de 
interpretar los derechos. He hablado del Convenio Europeo como una triple garantía, primero en cuanto tratado internacional, segundo como una garantía judicializada mediante el acceso individual de las víctimas, - lo que es probablemente otra cosa distinta-, tercero como una pasarela con el Derecho de la Unión que recibe su jurisprudencia primero como principios según el Tribunal de Justicia y desde el año 2000 en la Carta de Derechos Fundamentales de la Unión. Un Convenio a caballo de tres órdenes constitucionales: los nacionales, el del Consejo de Europa y el de la Unión. Un Convenio que es una de las principales limitaciones actuales a la soberanía de los Estados, que no existe ya en materia de derechos de forma absoluta, pues no cabe inmunidad ni impunidad ni otras patentes de corso frente a las violaciones que enjuicia el TEDH por encima de los Estados y con superioridad.

La apertura amistosa al Derecho internacional de los derechos humanos que hace el artículo 10.2 CE fortalece esta dimensión. La herramienta habitual es una interpretación de las leyes conforme a la Constitución y secundum conventionem, conforme al CEDH, entre otros tratados sobre derechos.

Una tercera característica es la desaparición del filtro que entrañaba la Comisión para permitir el acceso directo de las víctimas, y la consolidación de las medidas cautelares como plenamente vinculantes, algo que no dice el Convenio y sólo estaba en el Reglamento del Tribunal. Ambas cosas refuerzan la comprensión del sistema como una verdadera jurisdicción cuasi constitucional o en trance de llegar a serlo. Recordemos, que al principio, la Comisión mandaba al TEDH sólo algunas demandas, pero, desde 1998, las víctimas acceden directamente a la jurisdicción y el Tribunal selecciona desde el Protocolo 14 los asuntos que decide resolver por sentencia. El acceso directo de las personas físicas o jurídicas es el corazón del sistema del Convenio, dado el pequeño número de asuntos entre Estados ( 5 sentencias y 23 demandas) y del ejercicio de una competencia consultiva extrañamente regulada (artículos 47 a 49 CEDH), a la espera de saber qué ocurre con las nuevas opiniones consultivas que el Protocolo 16 introduce. La inadmisión o rechazo de las demandas infundadas, o repetitivas, o donde sólo se genera un pequeño prejuicio se ha convertido en una práctica prevista por el Convenio. El acceso per saltum a Estrasburgo en los países que carecen de un tribunal constitucional, o donde se pueden inadmitir las demandas sin trascendencia constitucional (léase el Caso Arribas Antón contra España, de 20 de enero de 2015) o grave daño a la parte, o donde no se tutelan en amparo constitucional todos los derechos es un problema al que hay que encontrar soluciones. He razonado al hablar de la reforma constitucional que las declaraciones de derechos constitucionales y sus garantías procesales deberían acomodarse simétricamente al CEDH y a la Carta de la Unión para evitarnos problemas.

Una cuarta característica ha sido el crecimiento constante de los derechos y la incorporación de contenidos nuevos a derechos viejos o, lisa y llanamente, nuevos derechos, incluida la protección por carambola de algunos derechos sociales al amparo de derechos civiles como han estudiado Pablo Santolaya e Ignacio García Vitoria. La dualidad entre CEDH y Carta Social Europea se ha amortiguado un poco por el TEDH aunque subsistan las dos vías de protección con intensidades diferentes. Los contornos de los derechos civiles y políticos protegidos ha venido creciendo constantemente. Tanto que no son extrañas opiniones británicas euroescépticas que sostienen que si hubieran sabido lo que era el Convenio Europeo en la realidad no lo habrían ratificado. También hay derecho viejos que se aplican a situaciones nuevas, porque los derechos son un case-law y sus 
disposiciones escritas mutan y se transforman constantemente al integrarse nuevos hechos en ellos y generarse otras normas en el constante proceso de especificación judicial de los derechos. ¿Quién habría pensado en la aplicación de la prohibición de esclavitud y trabajo forzado a las penosas condiciones de trabajo de algunos emigrantes irregulares? No obstante, esta expansión de los derechos, que han crecido como buena masa de pan, no olvidemos que los derechos del proceso debido y la prohibición de dilaciones indebidas han supuesto casi el $40 \%$ de los asuntos ingresados hasta 2017. Pero esta perspectiva estadística no es la más relevante.

Una quinta línea de evolución del sistema es el tránsito de las iniciales sentencias declarativas (así explicaba todavía las cosas no hace tanto el Consejo de Estado en su informe sobre el Derecho europeo) a unas sentencias plenamente vinculantes (artículo 46 $\mathrm{CEDH}$ ), legaly binding but not self-executing, que no se contentan con dictar condenas y compensaciones sino que avanzan cada vez más en la restitutio in integrum, reparando en la medida de lo posible el daño causado por la violación. Una constante jurisprudencia evolutiva ha generado esta resultado que ha impulsado y aceptado el propio Comité de Ministros. Claro está que no cabe una «declaración de nulidad» de una ley o una sentencia, como haría un tribunal constitucional, pero cabe que el TEDH declare una ley contraria al CEDH, una «declaración de incompatibilidad», que no es lo mismo, pero resulta casi igual a la larga si advertimos la cuestión con realismo, pues las obligaciones internacionales de los Estado imponen acomodar el Derecho interno.

El Tribunal dejó de leer el artículo $41 \mathrm{CEDH}$ contentándose con una indemnización o satisfacción equitativa, pero imperfecta, que sólo debe concederse si no puede repararse el daño con otras medidas ordinarias de cumplimiento. Se están hoy dictando medidas de reparación tanto individuales como generales: la puesta en libertad de personas detenidas, la reapertura de procesos judiciales, la exigencia de nuevas investigaciones de hechos, el reconocimiento público de responsabilidades, la restitución de propiedades expoliadas, la reapertura de lazos entre familiares y un largo etcétera. Esta nueva dimensión reparadora, aunada a la eficacia de cosa interpretada, cambian mucho las cosas y conceden una mayor eficacia a las sentencias del TEDH.

En sexto lugar, el diseño del CEDH otorga la responsabilidad de la ejecución a los Estados miembros y la supervisión de la misma a un órgano político como es el Comité de Ministros en el que están presentes los embajadores permanentes de los Estados. Un modelo distinto y plenamente judicializado al que la Corte Interamericana decidió luego seguir. Pero las cosas llevan tiempo evolucionando y se está produciendo una fusión. El Comité de Ministros ha desarrollado sus propios e interesantes métodos de trabajo a lo largo de los años ${ }^{2}$. Se han creado en Comité las llamadas reuniones de derechos humanos, asistidas del servicio técnico de ejecución de sentencias del TEDH ubicado en la secretaría del Consejo de Europa, así como se ha organizado un twin track supervisión system, una supervisión ordinaria junto a otra reforzada para los casos que requieren medidas urgentes y las sentencias piloto. Un sistema dual que funciona razonablemente. El Comité hace un seguimiento continuado de las medidas de ejecución de los Estados y pide que presenten un informe de ejecución y planes de acción, que

2 Cfr. el innovador estudio empírico de P. SaAvedra, G. Cano y M. Hernández: «Reparación y supervisión de sentencias »en J. García Roca y E. Carmona: ¿Hacia una globalización de los derechos? El impacto de las sentencias del Tribunal Europeo y de la Corte Interamericana, Thomson Reuters, Madrid, 2017. 
ordenan la lógica de la subsidiariedad, antes de cerrar la supervisión. El TEDH sigue sin ser responsable de la ejecución de sus sentencias, pero tras la presentación de una segunda demanda puede controlar la persistencia de violaciones o la aparición de otras nuevas. No obstante ha sido muy prudente en la apreciación de la directa vinculación de la obligatoriedad de las sentencias y la infracción del artículo 46 CEDH. Por último, la reforma de este artículo en dos nuevos apartados le ha dado al Tribunal nuevas herramientas, una demanda de interpretación y un recurso por incumplimiento de sentencias, técnicas que hasta ahora no han dado juego.

En suma, creo evidenciada la profunda transformación, mejora y crecimiento del sistema del Convenio merced a la jurisprudencia del TEDH —entre otras causas- y la valoración muy positiva que merece este fenómeno desde la lógica de una mejor garantía de los derechos y de la integración europea.

\section{LUIS JIMENA QUESADA}

Desde su creación, el TEDH ha sido y sigue siendo el buque insignia del Consejo de Europa como organización paneuropea por excelencia (fundada en 1949 y compuesta actualmente por 47 Estados miembros), lo cual se corresponde con su condición de instancia máxima de garantía del tratado continental más emblemático en materia de derechos humanos (el CEDH).

En efecto, de entrada, semejante posición emblemática del CEDH de 1950 derivaba, no tanto del catálogo de derechos que reconocía a nivel regional europeo (sólo algunos, como reza en su Preámbulo, de los previstos en la Declaración Universal de 1948) sino, sobre todo, del establecimiento de un recurso judicial individual ante el TEDH (al margen del sistema, poco operativo por razones político-diplomáticas, del sistema de demandas interestatales) mediante el que se erigía al individuo, a la persona, en sujeto (y ya no mero objeto) del Derecho Internacional. Se asumía así, como no podía ser de otro modo, de buen grado en el ámbito internacionalista, la emergencia de la nueva rama del Derecho Internacional de los Derechos Humanos, en donde adquiría protagonismo una novedosa corte internacional en la que los individuos podían llevar al banquillo y pedir responsabilidad a los Estados tras el agotamiento de los recursos internos.

El CEDH (con su TEDH a la cabeza) se configuraba como antídoto frente al totalitarismo que había provocado la Segunda Guerra Mundial y, por ello mismo, en el exponente más excelso de los tres pilares en los que se asienta el Consejo de Europa, es decir, la Democracia, el Estado de Derecho y los Derechos Humanos. Desde esta óptica, el impacto en el orden constitucional de los Estados miembros y, consecuentemente, en el terreno constitucionalista, era inexorable: en cuanto a lo primero, la incorporación del $\mathrm{CEDH}$ y la coherencia con la jurisprudencia del TEDH constituyen requisitos imprescindibles de pertenencia al Consejo de Europa (y, por lógica extensión y consecuencia, a la Unión Europea - UE-) y, por tal motivo, imponen adaptaciones y ajustes en el ordenamiento jurídico nacional (en su caso, en la propia Constitución nacional) y, más aún, en la cultura jurídica (piénsese en la relevancia de la asunción del CEDH en su día para el Reino Unido a través de la Human Rights Act de 1998; para darla a conocer al funcionariado, el Ministerio del Interior británico elaboró en su día la guía A New Era of Rights and Responsibilities - Core Guidance for Public Authorities, en donde se destacaba que el 
$\mathrm{CEDH}$ «establece nuevas responsabilidades para todos aquellos que trabajan en el sector público. Tenemos atribuida una función vital en la creación de una nueva cultura de los derechos humanos. Espero que esta Core Guidance sea un valioso instrumento para hacer realidad esa nueva cultura»); y, con relación a lo segundo, el peso de la jurisprudencia del TEDH en la docencia y la investigación constitucionalistas (del mismo modo que, transversalmente, en las demás ramas del Derecho) ha sido naturalmente creciente.

En estas coordenadas, la posición adoptada por el TEDH desde su instauración, ciertamente subsidiaria e inicialmente sin alardes de afectación a la soberanía estatal, ha servido de acicate para la transición y ulterior consolidación del orden constitucional democrático de las Partes Contratantes del CEDH, primero en los países occidentales y, tras la caída del muro de Berlín, en los países del centro y este de Europa. A tal efecto, la lógica de la consolidación de ese orden constitucional democrático habría debido conducir a una normal asunción de la jurisprudencia del TEDH (como parte integrante del sistema interno de fuentes del Derecho, en este caso de producción internacional) por parte de los actores implicados (en realidad, todos los poderes públicos y el conjunto de la ciudadanía) y esa parece ser la dinámica que podemos percibir con carácter general.

Sin embargo, la relevancia que la jurisprudencia del TEDH ha alcanzado en nuestros días en algunos campos singularmente sensibles (en especial, para la defensa del orden constitucional de los Estados frente al terrorismo y otras violaciones graves de los derechos humanos, que han puesto al TEDH ante la difícil tesitura de ponderar las restricciones impuestas a los verdugos y los derechos que, pese a todo, amparan a éstos) han fraguado y atribuido a la Corte de Estrasburgo una función de «indirizzo politico» que ha acabado por resultar molesta en ocasiones para las Partes Contratantes del CEDH. Y, a cuenta de ello, los Estados miembros del Consejo de Europa han llevado a cabo iniciativas correlativas de constricción del cometido del TEDH y acentuación del margen de apreciación nacional; me remito más detalladamente a la respuesta a la pregunta 4 (infra).

En todo caso, esas molestias han llegado a suscitar propuestas radicales (en Reino Unido) de «Brexit» no sólo respecto de la UE sino asimismo con relación al CEDH (para derogar la Human Rights Act de 1998 por una nueva British Bill of Rights: vid. BoYLE, K. y CoChrane, L.: «Brexit and British Bill of Rights: four scenarios for human rights», The UK in a Changing Europe, Research papers, King's College London, 2017), o debates crispados (en España) sobre determinadas resoluciones de la Corte de Estrasburgo (acusadamente, la STEDH Del Río Prada c. España de 21 de octubre de 2013 sobre la llamada «doctrina Parot») que han oscilado entre una pretensión inviable de «ingeniería jurídica» tendente a eludir el cumplimiento y una posición irreflexiva de seguimiento sin matices de tales resoluciones.

Dicho lo cual, para reducir o paliar los perniciosos efectos de ese marco oscilatorio, se impone una importante tarea de pedagogía acerca de la indiscutible relevancia de la jurisprudencia del TEDH como exponente fundamental de una cultura europea de derechos humanos que debe contribuir a fortalecer nuestro sentimiento constitucional. Y, en este sentido, un ejercicio de autocrítica nos debería llevar a reconocer que, desde la doctrina constitucionalista, no hemos mostrado una correcta aprehensión de la importancia del CEDH y de la jurisprudencia del TEDH susceptible de ser transmitida a través de la enseñanza y la investigación en la Universidad o por medio de un debate sereno en sede política, mediática o más ampliamente social. 
Con tal enfoque, todavía eran extrañas a inicios de los años noventa del siglo pasado las investigaciones (incluidas las tesis doctorales) sobre la jurisprudencia del TEDH en el constitucionalismo (como si no versaran sobre Derecho Constitucional), lo mismo que se precisó una especia de operación de marketing constitucional a principios de los 2000 (primero con la Carta de los derechos fundamentales y luego con el fallido intento de adopción de un «Tratado por el que se establecía una Constitución para Europa») para que nos ocupáramos con determinación del Derecho de la UE.

En realidad, el desafío de la correcta aprehensión de la jurisprudencia del TEDH todavía persiste, tanto en el plano académico (para situarla adecuadamente en el insoslayable panorama del constitucionalismo multinivel, propiciando un fluido diálogo con las jurisdicciones supremas de los Estados miembros y con el Tribunal de Justicia de la UE), como en el terreno social (las críticas acerbas e infames dirigidas desde algunos medios de comunicación, ciertas esferas políticas y varios círculos sociales, tanto frente a Luis López Guerra en su labor de juez del TEDH como contra la recién elegida jueza del TEDH María Elósegui Itxaso antes incluso de entrar a ejercer sus funciones, ponen de manifiesto una ostensible falta de respeto institucional hacia el TEDH ligada al desconocimiento de su sistema de elección y de su jurisprudencia).

Por tal razón, en suma, desde la Universidad (y, en este caso, desde el Derecho constitucional), tenemos una responsabilidad, no sólo académica, sino también social (al intervenir en medios de comunicación o como asesores de la clase política), para que además de la coherencia cotidiana (por parte de todos los operadores jurídicos) con la jurisprudencia del TEDH, no tergiversemos el alcance de ésta en debates como el de la prisión permanente revisable (véase, sobre todo, la STEDH Vinter y otros c. Reino Unido de 9 de julio de 2013, párrafos 119-112), o no banalicemos el papel de la Corte de Estrasburgo dando pábulo a peticiones descabelladas de medidas cautelares o demandas individuales abusivas (como está ocurriendo con los pretendidos adalides del proceso secesionista en Cataluña).

\section{CARLOS RUIZ MIGUEL}

Creo que, como punto de partida, para analizar el papel desempeñado por el TEDH hay que adoptar una postura crítica alejada de una, a mi juicio, frecuente e indeseable alabanza de este papel. Debemos partir, al menos como hipótesis, de que no todo lo «europeo» es necesariamente positivo y que puede que lo «europeo» y, en este caso, el TEDH haya tenido aportaciones positivas, pero también negativas. Sin admitir como punto de partida que el TEDH puede tener impacto positivo, pero también negativo, no es posible un análisis verdaderamente crítico.

El TEDH, sin ninguna duda, ha adquirido una importancia grande en España, mayor de la que ha adquirido en otros países europeos. El mayor impacto de la jurisprudencia del TEDH en España se debe a varios factores, jurídicos, pero también políticos. El primero, es que el artículo 10.2 establece que las normas internacionales sobre derechos humanos son un criterio interpretativo sobre las normas constitucionales de derechos fundamentales que se añade a los otros criterios de interpretación. Dado que, de entre las normas internacionales sobre derechos humanos, el CEDH es el que contiene un mecanismo de interpretación más elaborado, encomendado al TEDH, parece lógico que 
haya sido el CEDH, en la interpretación dada por el TEDH, la norma internacional más invocada por la jurisprudencia constitucional española. El segundo, es el hecho de que el CEDH es una norma directamente aplicable en España dado que el artículo 96 CE establece un modelo monista de relación entre el Derecho nacional y el internacional. El tercer factor es ya político, y no jurídico. Las peculiaridades de la transición política española y de la configuración de las opciones políticas en presencia han llevado durante muchos años, sobre todo (aunque no sólo) desde planteamientos de izquierda, a «des-nacionalizar» España. Esta ideología des-nacionalizadora ha llevado a sobrevalorar, por un lado, los nacionalismos regionales y, por otro, lo «europeo». Como consecuencia de este prejuicio, el Derecho «europeo» (ya proviniera del marco de la UE o del Consejo de Europa) tenía un «plus» gratuito de prestigio que, a mi juicio, no estaba justificado ni por el contenido de la norma en sí ni por la calidad de los jueces o de las resoluciones judiciales europeas. Todos estos factores han llevado a que la «legitimidad» atribuida al Derecho «europeo» en España sea mucho mayor que la que se otorga en otros países.

Hecha la advertencia anterior considero que la relevancia de la jurisprudencia del TEDH a veces se debe a sus aciertos, otras a sus errores y, en ocasiones, finalmente, a que ha permitido amplificar doctrinas generadas en otros tribunales.

Aunque muchos lo incluyan en su «haber» soy de los que consideran que deben incluirse en el «debe» del TEDH una parte de su jurisprudencia sobre libertad de expresión y sobre el derecho a la protección de la vida privada y familiar. Dejo las consideraciones sobre la libertad de expresión para la última parte de esta encuesta. En relación con el derecho a la protección de la vida privada (art. $8 \mathrm{CEDH}$ ), aunque el TEDH ha hecho aportaciones muy positivas, otras veces creo que su contribución ha sido censurable. Así ha ocurrido con la interpretación activista del «respeto a la vida familiar» que entendida de modo laxo llevó a reconocer el, hasta entonces inexistente, derecho a la «reagrupación familiar» en sentencias como la del caso Abdulaziz, Cabales y Balkandali (de 28 de mayo de 1985) o a hacer imposible una expulsión de un extranjero condenado penalmente, como en los casos Moustaquin (de 18 de febrero de 1991) o Beldjoudi (de 26 de marzo de 1992), todo ello al mismo tiempo que no se veía obstáculo en que el Estado pudiera privar a un padre de su hijo, como en la sentencia Olsson n. 2 (de 27 de noviembre de 1992).

Por el contrario, han resultado especialmente útiles algunas aportaciones del TEDH en materia de derechos procesales (art. $6 \mathrm{CEDH}$ ). Pensemos en construcciones como la referida a la imparcialidad del juez o al plazo en el que deben resolverse los procesos judiciales. En el haber de la jurisprudencia del TEDH, por cierto, no siempre debidamente aprovechado en España, se hallan algunas doctrinas establecidas en torno al derecho a la protección de la vida privada (art. $8 \mathrm{CEDH})$. Sus sentencias acerca del secreto de las comunicaciones de 1990 (casos Kruslin y Huvig) resultan, casi 30 años después, especialmente valiosas a la hora de examinar el tratamiento jurídico que debe aplicarse a los «meta-datos» (o big data). Igualmente creo que la jurisprudencia constitucional española se ha equivocado al construir un «derecho a la protección de datos» separado del derecho a la intimidad, apartándose en este punto de la doctrina del TEDH (baste citar, por todas, la sentencia S. y Marper c. Reino Unido, de 2008).

También debe destacarse el papel que ha tenido el TEDH amplificando doctrinas previamente sentadas por otros tribunales de la constitucionalidad. Así, por ejemplo, su doctrina (expresada en la sentencia de 1968 sobre el régimen lingüístico belga) sobre el derecho a la igualdad (art. $14 \mathrm{CEDH}$ ) no es original, pues recoge la construcción del 
Tribunal Constitucional Federal Alemán (que a su vez se ha inspirado en el Tribunal Supremo de los Estados Unidos), pero ha servido para que en muchos otros países la misma pueda ser conocida y acogida.

\section{ROSARIO TUR AUSINA}

Es bien conocido el extraordinario valor derivado de la voluntad de los Estados a mediados del s. xx de someter al escrutinio de una organización supranacional compleja su acervo interno. En virtud de una mutua relación de confianza, se fue apostando por construir unos mínimos estándares comunes constitucionales, en un recíproco y paulatino movimiento de renuncias y beneficios, con el cierto sacrificio incluso de singularidades y protagonismos estatales, pero con la mirada puesta en un compromiso por una libertad-igualdad compartida. En esta ardua tarea el TEDH adquiría especial protagonismo, en uno de los avances más significativos y ambiciosos del derecho constitucional supranacional. A nadie se le escapaba que ya entonces era un reto el fenómeno de la «globalización», tan actual hoy, pero en efecto nada reciente.

La globalización configuraba un nuevo contexto irremediablemente tolerado y en cierta medida buscado por los Estados, con fuertes aperturas a la negociación entre poderes interestatales; se ligaba además a la existencia previa de fuertes dosis democráticas nacionales como conditio sine qua non para la pertenencia al Consejo de Europa y para el correcto funcionamiento del diálogo del Tribunal de Estrasburgo con las instancias nacionales; y obligaba a tomar conciencia de que nuestros sistemas constitucionales están en permanente construcción y se ven permeados por circunstancias ajenas a los intereses puramente estatales. Un sistema maleable e irreversible, que dificulta el alcance de consensos, que genera importantes tensiones entre el respeto hacia lo propio y la aceptación de lo diverso, pero que ofrece una integración constitucional que beneficia y hace más fuertes a los Estados, conformando un ámbito de riqueza intercultural común, compatible y colaborativo en materia de derechos. En el fondo, se trataba de hacer valer la universalidad de los derechos desde la diversidad propia de sus titulares, pero donde los Estados desde su propia fisonomía reivindican su derecho a seguir liderando el proceso para abrirse - con ciertas complacencias o resistencias dependiendo del momento temporal y de las relaciones de poder- a espacios supranacionales compartidos.

Pero la globalización también presentaba una doble cara que es a la vez una doble tensión para los Estados, palpable en la realidad del TEDH. Si por un lado aquella intenta superar los límites nacionales (auténtica base universal para los Estados), por otro la globalización también impone una fragmentación por sectores de intereses (con particularismos e identidades) que intentan construir una lógica autónoma (Teubner, Sassen, Krasner, Estado, Soberanía y Globalización, 2012). En resumidas cuentas, la racionalidad estatal no deja de sentirse amenazada cada cierto tiempo, lo que genera una doble paradoja: de una parte, los países más acostumbrados a la negociación y al pacto, con una más o menos sólida tradición democrática, parecen blindarse y cerrarse a ciertos empujes de instancias supranacionales (piénsese en las recientes respuestas del Reino Unido y el Brexit, las clásica resistencia francesa, o la más reciente alemana, por no mencionar las reticencias a cierta jurisprudencia sensible que afecte al fenómeno religioso, la vida, la inmigración, etc.); de otro lado, son los países con dificultades los que se abren y 
depositan su esperanza democrática en las instancias supranacionales, mientras el poder se blinda internamente. $\mathrm{Y}$ es que si ya estaba en crisis el concepto mismo de soberanía ligado a la idea de Estado — pues cuesta entender aún que existe soberanía pero no un único soberano- , ahora también parece cuestionada —o quizá siempre lo estuvo— la unidad del orden internacional. El pluralismo, la diversidad, la separación de sistemas, la compleja acomodación en un mundo tremendamente cambiante por las nuevas tecnologías,... provocan un oculto desasosiego que no debe llegar al dramatismo.

El reto constante ha sido el de construir un sistema constitucional multinivel, en una relación entre sistemas funcionales, con una Constitución global o un pluralismo constitucional no jerárquico, de carácter relacional, y que reconoce espacios constitucionales autónomos aunque unidos mediante mecanismos e instrumentos de producción del derecho. La configuración de un ordenamiento sin contradicciones sólo es posible, en consecuencia, desde el fomento de una cultura del pacto y con las necesarias reglas para el diálogo y la resolución de conflictos (Luhman, Sistemas sociales. Lineamientos para una teoría general, 1998). Porque el constitucionalismo europeo multinivel, que todavía necesita esfuerzos doctrinales para constituir una auténtica categoría dogmática, es tiránico cuando pierde o le falla la estructura, el orden y la seguridad que se desprende de un desarrollo coherente de la Convención de Roma y de un adecuado self restraint jurisprudencial, en armonía con las tradiciones constitucionales, pero siempre en la búsqueda constante de los más altos estándares en materia de derechos humanos. La jurisprudencia de Estrasburgo es y ha sido, en ese sentido, un importante dinamizador del sistema. Lo suficientemente ágil como para responder a importantes obstáculos y retos, pero también convenientemente respetuoso y consciente del espacio que corresponde a las instancias nacionales.

Pero en este balance, para seguir armando la arquitectura europea sigue habiendo cuentas pendientes. Más allá de problemas jurídicos concretos que plantea el Convenio, quizá un mayor compromiso social, político y mediático, que pasa por profundizar en la formación jurídica de todos los operadores que interactúan en el sistema europeo, de tal forma que las instancias nacionales sean capaces de hacer suya la Europa de los Derechos. En consecuencia, empezando por desechar lecturas e interpretaciones precitadas que se limitan a transmitir el diálogo europeo desde el marco del conflicto y la confrontación; en definitiva, evitando un modelo de adversarios, pues el proyecto europeo siempre fue concebido de forma totalmente opuesta. Para confirmar este marco conflictivista que inunda la realidad social, política y jurídica, basta en la vida cotidiana con observar cómo la jurisprudencia europea se convierte en el centro de atención — siempre en clave negativa - cuando se producen determinadas condenas a nuestro Estado, o cómo se recurre - precipitadamente, sin el suficiente análisis que toda decisión jurídica compleja requiere- a la doctrina europea para su confrontación con una decisión tomada en sentido contrario por una instancia nacional, sin entender bien lo que es en realidad un diálogo entre Tribunales.

Se olvidan así tantos elementos positivos —e incluso negativos- que deberían verse como una oportunidad para el progreso. Diversos ejemplos ocultan a veces tantas décadas de esfuerzo. Es lo que ocurre con la inadecuada interpretación de las estadísticas, pues España no es ni de lejos uno de los países más condenados; con el olvido del refuerzo positivo que hace Estrasburgo en la delimitación de diversos derechos que así pudieron haber sido interpretados por algunas instancias nacionales aunque no por otras; o con la 
falta de conocimiento de las recomendaciones constructivas y sugerentes que realiza a partir de la acumulación de otros acervos y que pueden enriquecernos. Pero incluso se pierde de vista que una decisión aparentemente involucionista puede esconder diversos mensajes que permitan el avance, como cuando una resolución advierte — no siempre en la ratio decidendi- de un problema endémico en los Estados, o de una peligrosa deriva para los derechos que no es suficientemente advertida y que corre el riesgo de convertirse en estructural. No es fácil vivir en un pluralismo constitucional si no se incrementa la cultura multinivel, que pasa por el aumento de la propia cultura constitucional interna. Piénsese, a modo de ejemplo, que el margen de apreciación nacional dejado a los Estados, no debe verse sin más como una reducción generalizada del estándar de protección de los derechos ni como una dejación de funciones del TEDH, sino como la evidencia de aspectos necesitados de consenso y diálogo.

En un balance rápido, pocas dudas tenemos sobre el enfoque antropocentrista proactivo del Consejo de Europa, sostenido a través de la intensa labor de Estrasburgo. Pero su fracaso o su éxito bebe de aquello de lo que se nutre, los Estados, y por ello todo resquicio o síntoma de crisis puede tener un efecto contagio que requiere de la alerta constante del Tribunal, para no acabar contaminando el propio proyecto europeo. En su capacidad para mantener viva esta alerta - y no tanto para decidir por los Estados mismos - estará la supervivencia de la Europa de los Derechos. Más si cabe cuando tiene ante sí otra verdad europea, la de la Unión, que antepuso un enfoque mercantilista basado en el predominio de la libertad sobre la igualdad, y que aún lucha por moverse hacia el humanismo. Y más todavía cuando caminamos hacia un mundo donde prima la comunicación de la era de Internet, cuyos ciertos riesgos — quizá por su inmediatez- de precipitación, visceralidad y desinformación pueden suponer una nueva deshumanización, por mucha causa social que diga abanderarse.

El éxito de Estrasburgo es evidente, y por ello mismo ha sido un reto de los últimos tiempos centrar bien sus esfuerzos para, precisamente, evitar morir de éxito, lo que esconde en realidad un probable alejamiento estatal de la Europa de los Derechos. En esta línea, y con acierto a nuestro juicio, el futuro pasa por llevar la Europa de los Derechos a las instancias nacionales al tiempo que convertir a Estrasburgo en el faro que guía y ayuda a ello. Es lo que ha impulsado a que las últimas reformas se hayan orientado al refuerzo de su papel como instancia dirigida a resolver lesiones de derechos derivadas de problemas estructurales o que implican un daño «grave» (Protocolo n. ${ }^{\circ}$ 14). La reforma se inscribió en la idea de dejar de concebir al Tribunal de Estrasburgo como órgano tutelar cotidiano de los derechos, sustitutivo de las instancias nacionales. Por ello, esta especie de hipersubjetivización (daño subjetivo grave) del amparo supranacional, en nuestra opinión esconde una objetivización manifiesta: la especial gravedad del daño deriva de la importancia que, para el desarrollo y equilibrio del completo sistema de derechos, tiene un litigio concreto. Pero también es verdad que esta reforma requiere del refuerzo de la tutela de los derechos por las instancias nacionales así como de la intensificación del diálogo. Por ello, en la misma línea de incrementar el protagonismo y, por lo tanto, de empoderar a las instancias nacionales, se encuentran los Protocolos 15 (eliminación de la cláusula de salvaguardia que impedía inadmitir demandas por falta de perjuicio importante cuando el asunto no hubiera sido debidamente analizado por un tribunal nacional; introducción en el preámbulo del convenio del principio de subsidiariedad y del margen de apreciación nacional; eliminación del derecho de veto del Estado demandado a que 
una Sala se inhibiese a favor de la Gran Sala) y 16 (que permite que los Altos Tribunales nacionales dirijan opiniones consultivas al TEDH), porque tan importante es que el Tribunal de Estrasburgo mantenga viva la llama del Convenio como que los Estados hagan suya la idea de la Convención y del entero proyecto europeo.

2. ¿Nos puede facilitar su opinión acerca de si el eventual conflicto entre una Ley y un Tratado Internacional debe ser resuelto directamente por el Juez nacional, o si este debe plantear la denominada Cuestión de Convencionalidad?

\section{ENOCH ALBERTÍ ROVIRA}

Hoy existen ya pocas dudas acerca del carácter supralegal de los tratados internacionales y de cómo entender la relación entre tratados y leyes a la luz del art. 96 CE. La posición de prevalencia de los tratados, por si no estaba claro aún, ha sido confirmada, que no establecida, de forma expresa por la Ley 25/2014, de tratados internacionales. Su art. 31 reza, en efecto: «Las normas jurídicas contenidas en los tratados internacionales válidamente celebrados y publicados oficialmente prevalecerán sobre cualquier otra norma del ordenamiento interno en caso de conflicto con ellas, salvo las normas de rango constitucional», en lo que no puede dejar de considerarse un mandato explícito a los operadores jurídicos y, especialmente, a los jueces. Así pues, en virtud del art. 96 CE (que la Ley 25/2014 sólo concreta), los tratados internacionales gozan de primacía respecto de la ley - y de cualquier otra norma interna, salvo la Constitución_-, lo cual conduce a la preferencia en su aplicación en caso de conflicto, con un efecto de desplazamiento de la ley o de cualquier otra norma interna que los contradiga.

En realidad, como se puede apreciar fácilmente, nada nuevo, pues el principio de primacía de los tratados de la UE — y del entero ordenamiento comunitario europeoya estaba firmemente asentado y había sido aceptado sin excesivos problemas por el propio Tribunal Constitucional. Lo que ocurre ahora es que esta regla de relación, que deriva en última instancia del principio pacta sunt servanda sin el cual deja de existir el derecho internacional, se aplica al conjunto de tratados suscritos por España y no sólo a los relativos a la Unión Europea y a su derecho, que encuentran su fundamento específico en la cesión de soberanía que habilita el art. $93 \mathrm{CE}$.

Ahora bien, una vez resuelta la cuestión sustantiva de la relación entre tratados y leyes, no está a mi juicio nada claro que la única solución posible para hacer prevalecer los tratados frente a las leyes sea precisamente un control de convencionalidad difuso, a cargo de cualquier órgano judicial que, en el ejercicio de su labor jurisdiccional, deba necesariamente, y por sí mismo, anteponer un tratado a una ley para resolver una cuestión sometida a su conocimiento. Creo que esta solución, que es la adoptada en el ámbito de los derechos fundamentales por la Corte Interamericana de Derechos Humanos, que ha impuesto a los Estados parte de la Convención un control difuso de la misma, es sin duda una solución posible — y creo, además, que acertada — , pero hay que reconocer que cabría otra alternativa, que en general podemos calificar como de control concentrado, y que residenciaría dicho control en un órgano jurisdiccional superior (el TC, en general). Así se ha defendido por algunos autores entre nosotros (Raúl Canosa, p.ej.,), alegando 
básicamente razones de seguridad jurídica. No hay duda de que el control concentrado gana en seguridad, frente al riesgo de dispersión (no creo que se produjera sin embargo ningún «caos», como alguna vez se ha dicho), pero pierde en agilidad, al dilatar, quizá enormemente, la resolución judicial del asunto original. Y, además, presenta también algún problema técnico, pues el TC se ha manifestado repetidamente en el sentido de que el derecho europeo (ni el comunitario ni el CEDH) constituyen parámetros de constitucionalidad que le permitan controlar las leyes. Y aunque esta objeción, importante, pudiera solventarse acudiendo a la técnica de la inconstitucionalidad mediata (una ley interna contraria a un tratado sería, por este motivo, también inconstitucional debido al art. 96 CE), no deja de forzar el ámbito de actuación del TC. Por ello, se ha propuesto la reforma de la Constitución para acoger este sistema de control de la convencionalidad, lo cual es una dificultad añadida para su adopción.

El control difuso, a cargo de cualquier órgano judicial interno y en términos de prevalencia (y por tanto, de aplicación al caso concreto, y no de eficacia general, de vigencia ni mucho menos de validez) presenta sin embargo, a pesar de resultar a mi juicio el más consistente con nuestro sistema, algunos riesgos claros de inseguridad por la diversidad de intérpretes que pueden intervenir. Este riesgo incluso es mayor que en relación con el derecho comunitario europeo, pues no existe un mecanismo de reenvió, como la cuestión prejudicial de interpretación ante el TJUE, que pueda jugar un papel unificador (en el caso del TEDH este papel lo jugaría hoy sólo la jurisprudencia dictada en los casos individuales que resuelve y, en su caso, las opiniones consultivas que emita). Ello podría mitigarse en parte con el Protocolo n. ${ }^{\circ}$ 16, de 2013, que establece un sistema de consultas de las «altas cortes y tribunales» al TEDH, que podrían solicitar su opinión consultiva sobre la interpretación de los derechos y libertades definidos en la CEDH y sus protocolos. Pero la opinión emitida por el TEDH no tiene en ningún caso carácter vinculante y, en todo caso, España, al ratificar el Protocolo (hoy ni siquiera lo ha firmado) debería indicar cuáles son los órganos judiciales que pueden solicitar esta opinión consultiva del TEDH con un criterio, entiendo, lo más amplio posible, estando como se está ante un sistema de control difuso.

No obstante, el riesgo de inseguridad que puede generar el control difuso se encuentra, creo, bastante atenuado. Este control hoy ya es posible, pero en realidad se ha aplicado, al menos en materia de derechos fundamentales, en muy pocos casos, especialmente en el ámbito de la jurisdicción social. Esta atenuación del riesgo de inseguridad debido a la dispersión del control se fundamenta, por una parte, en el hecho de que los textos internos (Constitución y legislación) e internacionales (CEDH y protocolos anejos ratificados) mantienen un muy alto grado de coincidencia y compatibilidad. A ello contribuye que la Constitución de 1978 y la legislación de desarrollo de los derechos fundamentales sean posteriores al Convenio de Roma, y que en gran parte éste sirviera de inspiración y referencia para las normas internas. Ello no excluye naturalmente que puedan producirse algunas discrepancias no reconciliables, y ahí se encuentran sin duda los problemas. Pero son casos muy limitados. Y, por otra parte, el riesgo se atenúa también debido a que la práctica judicial en materia de derechos, incluida, y quizá principalmente la del Tribunal Constitucional, ha integrado, en general, art. $10 \mathrm{CE}$ mediante, la jurisprudencia del TEDH, de modo que la interpretación interna de los derechos ha incorporado la doctrina del TEDH, con escasas excepciones (aunque en algunos casos, menos de lo que dice que hace). Hoy, p.ej., ningún juez puede poner en duda en España que los ruidos excesivos constituyen una inmisión 
ilegítima en el derecho a la intimidad domiciliaria de las personas. La doctrina López Ostra del TEDH fue acogida —al menos en lo que en este punto se refiere- por el TC y después ha irradiado a todos los órganos judiciales, de modo que se ha incorporado a la interpretación interna del derecho a la intimidad personal y familiar. Este acogimiento de la jurisprudencia del TEDH disminuye, desde luego, la posibilidad de colisión. Y, además, este riesgo se atenúa también mediante el sistema de recursos, pues la decisión de un órgano judicial de desplazar la ley interna, en un caso concreto, para aplicar el CEDH puede ser revisada en las instancias correspondientes, alcanzando quizá el Tribunal Supremo y, en todo caso, si se trata de derechos fundamentales, el Tribunal Constitucional.

\section{JUAN MARÍA BILBAO UBILLOS}

En mi opinión, el control interno de convencionalidad es posible en nuestro país a tenor de lo dispuesto en el artículo 96.1 CE ( «Los tratados internacionales válidamente celebrados, una vez publicados oficialmente en España, formarán parte del ordenamiento interno. Sus disposiciones sólo podrán ser derogadas, modificadas o suspendidas en la forma prevista en los propios tratados o de acuerdo con las normas generales del Derecho internacional») No creo, por tanto, que sea objetable en el plano dogmático. Sobre el papel, con arreglo siempre a nuestro sistema de fuentes, un precepto legal en vigor puede verse desplazado en caso de conflicto por una norma de un tratado internacional ratificado por España, previa autorización de las Cortes, y publicado en el BOE.

Es verdad que nuestros jueces, quizá por el sesgo netamente positivista de su formación, conciben la exigencia de sometimiento al imperio de la ley de forma muy estricta, y esa concepción ortodoxa les lleva a descartar la posibilidad de inaplicar por sí mismos una norma interna si ésta entra en conflicto con una disposición contenida en un tratado internacional en materia de derechos humanos. Tienen plena conciencia de su papel como parámetro interpretativo de primer orden (art. 10.2 CE), pero son reacios a reconocer esa eficacia directa, esa fuerza activa en relación con las leyes internas. Sólo se registra, como excepción a la regla, alguna que otra decisión aislada en la que se reconoce ese valor supralegal y se actúa en consecuencia, casi siempre en la jurisdicción laboral. Y eso que los tribunales españoles vienen asumiendo con naturalidad ese desplazamiento en virtud del principio de primacía y efecto directo del Derecho de la Unión Europea, que se resuelve en la aplicación preferente de la norma comunitaria.

Con independencia de cuál sea su encaje teórico, a nadie se le ocultan las dificultades y las posibles contraindicaciones de la puesta en práctica de un control difuso de convencionalidad como el instaurado desde 2006 en el marco del sistema interamericano (CIDH). Esta herramienta en manos de jueces activistas que tuviesen un amplio conocimiento de las normas del Convenio y la jurisprudencia del TEDH (condición indispensable para poder ejercer ese control) podría ser muy perturbadora. Mientras no exista en el ámbito del Convenio Europeo una vía equivalente a la cuestión prejudicial ante el TJUE (una suerte de «cuestión de convencionalidad»), parece más prudente recomendar a nuestros jueces la alternativa de la cuestión de inconstitucionalidad ante el Tribunal Constitucional cuando alberguen alguna duda sobre la compatibilidad de una disposición con rango de ley con lo previsto en el CEDH o en otro tratado internacional. De ese modo, se garantiza mejor la seguridad jurídica y la igualdad en la aplicación de la ley. 


\section{VÍCTOR FERRERES COMELLA}

La jurisprudencia del Tribunal Constitucional español es clara con respecto al control de las leyes desde el punto de vista de su conformidad con los tratados internacionales suscritos por España. El Tribunal ha entendido que la posible contradicción entre una ley y un tratado es un problema de legalidad ordinaria que incumbe resolver a los jueces ordinarios. A mi juicio, sin embargo, esta regla general debería ser objeto de una excepción cuando el tratado internacional que sirve de parámetro versa sobre derechos fundamentales, como es el caso del Convenio Europeo. En mi opinión, debería mantenerse aquí el monopolio de rechazo de las leyes que ostenta el Tribunal Constitucional, como se ha hecho en otros países (Italia y Austria, por ejemplo). Las razones que justifican la centralización del control de constitucionalidad de la ley en manos del Tribunal Constitucional operan con la misma fuerza cuando el control que debe efectuarse sobre la ley se basa en el Convenio Europeo. En coherencia con ello, y desde un punto de vista exegético, habría que entender que el artículo 10.2 de la Constitución es lex specialis respecto del régimen general que el Tribunal Constitucional ha construido a partir del artículo 96 de la Constitución.

\section{JAVIER GARCÍA ROCA}

Me centraré, no en todos los tratados, si no en los conflictos entre las leyes nacionales y el CEDH y la jurisprudencia que de él emana. Una interpretación conforme es el escenario habitual. En España esta interpretación se hace cada vez más frecuentemente por el Tribunal Constitucional — según ha revisado Argelia Queralt—y por los demás tribunales y lo mismo en otros países europeos. El juicio de convencionalidad suele agotarse en una interpretación de las normas doblemente conforme, a la Constitución y al CEDH, una interpretación constitucional secundum Conventionem.

Una interpretación correctora «hasta donde sea posible» puede ser suficiente como mecanismo de control de convencionalidad. Así la Human Rights Act, que incorporó el Convenio al Reino Unido en 1998, impuso la necesidad de interpretar las leyes y los reglamentos de conformidad con el Convenio «so far is it is posible». Una obligación de leer los preceptos legales y darles eficacia de una manera compatible con los derechos convencionales. Pero este mandato legal británico está en la naturaleza de las cosas. Sin embargo, el alcance de una interpretación conforme debe detenerse allí donde la literalidad del precepto lo impida. No resta entonces otra salida que la inaplicación judicial en los supuestos de insalvable contradicción. Más debe ser una última posibilidad tras intentarse una interpretación conforme.

No tengo constancia de supuestos de inaplicación de la ley en España derivados del sistema del Convenio. No es una situación frecuente. ¿Sería posible? En la mayoría de los países europeos, no se reconoce expresamente la primacía del CEDH tal y ocurre en cambio para las normas de la Unión; y a diferencia del principio de preferencia que se establece para los tratados sobre derechos en la Constitución de Brasil y en otros países latinoamericanos. Pero podría introducirse esta previsión constitucional.

Sin necesidad de esta reforma, si el Convenio Europeo en cuanto tratado tiene rango constitucional, o superior a al constitución, o incluso infraconstitucional pero supralegal 
como ocurre en España, el órgano judicial nacional debería aplicar el tratado con preferencia a la ley en supuestos de antinomias o contradicciones normativas. La Ley española 25/2014, de 27 de noviembre, de tratados y otros acuerdos internacionales, resuelve la incógnita en este mismo sentido (artículo 31) recogiendo expresamente la prevalencia de los tratados frente a las leyes. Un principio jurídico que puede considerarse inmanente a estas antinomias y, en consecuencia, extrapolable a otros países.

En efecto, en Derecho comparado, la inaplicación judicial del Derecho nacional que contraviene el Convenio no puede negarse. Así ocurre claramente en los países europeos donde el CEDH tiene rango constitucional. Giuseppe Martinico ha recopilado información sobre algunos países. Holanda reconoce la prevalencia del Derecho internacional sobre el Derecho interno al tratarse de un verdadero sistema monista, y se establece que las normas legales no pueden aplicarse si están en conflicto con las previsiones de los tratados internacionales por su carácter vinculante. Esta cláusula obliga al control de convencionalidad. En Austria, se ha reconocido — de hecho- carácter constitucional al $\mathrm{CEDH}$ y los conflictos entre la Constitución y el CEDH se gobiernan por el principio «lex posterior derogat legi priori». En Bélgica, algunos académicos consideran los dos Derechos europeos como superiores al nacional. En los países escandinavos, se contempla el $\mathrm{CEDH}$ como lex superior en la práctica judicial, pese a las escasas bases normativas para ello. Algo ha ido cambiando pues en muchos ordenamientos europeos incluso basándose en previsiones constitucionales que no son muy explícitas. Pero no en todos. En «Pautas para una reforma constitucional. Un Informe para el debate» sugerimos incorporar en la Constitución el CEDH y la Carta de Derechos Fundamentales de la Unión y otorgarles rango constitucional.

En el ámbito interamericano, las constituciones de Argentina, Bolivia, Costa Rica, Ecuador, México, Venezuela, otorgan rango y fuerza constitucional a los tratados de derechos humanos. Se habla de un bloque de convencionalidad. Incluso se ha defendido, desde la perspectiva doctrinal por Nestor Sagüés, la interesante idea de una «constitución convencionalizada». El escenario latinoamericano para la inaplicación judicial parece tener mayores bases normativas que el europeo. Pero no por ello deja de ser una decisión menos arriesgada y la prudencia en los comportamientos judiciales parece aconsejable.

En la realidad, insistiré en que las contradicciones normativas no son frecuentes en Europa y suele bastar con acomodar la ley nacional mediante una interpretación judicial conforme que tenga un alcance corrector de algunas aristas lesivas de derechos. No resta un gran espacio para la inaplicación judicial.

La situación parece diversa con el Derecho de la Unión, mucho más reglamentista y con un escaso margen para la acomodación de la ley nacional por vía exegética, y donde sí se producen inaplicaciones por ejemplo en materia tributaria. Pero las normas y la jurisprudencia convencional europea sobre derechos son mucho más elásticas o dúctiles y esto hace casi siempre posible una interpretación correctora.

Con la reciente entrada en vigor del Protocolo 16, que introduce una «opiniones consultivas», podrían producirse cambios significativos que desplacen aún más la inaplicación, al cabo la tradición europea no es la de una jurisdicción constitucional difusa. Se incorpora una suerte de cuestión prejudicial o cuestión de inconvencionalidad semejante a la cuestión de inconstitucionalidad. A través de este procedimiento, los altos tribunales nacionales podrán, «only in the context of a case pending before it» (artículo 1.1), pedir al 
TEDH una opinión consultiva (advisory opinions) sobre cuestiones de principio relativas a la interpretación o aplicación de los derechos definidos en el Convenio y sus Protocolos. Existe pues prejudicialidad y concreción: un juicio a quo que por reenvío y con carácter devolutivo produce otro ad quem ante el TEDH

Este procedimiento inevitablemente propiciará antes o después que el Tribunal de Estrasburgo se pronuncie sobre la convencionalidad de una norma nacional. Y aunque el Protocolo 16 establece que la opinión del Tribunal Europeo no es vinculante (artículo 5), barrunto que es un mero brindis al sol, pues lo acabará siendo en la realidad de las cosas para todos los Estados partes y no sólo para el Estado requirente en la medida en la que, si cualquiera de ellos se separase de la interpretación ofrecida por el Tribunal, se propiciaría que demandas de reclamantes individuales dieran ocasión al TEDH en casos concretos de reafirmar su posición e imponer su criterio de forma vinculante. Al cabo no es de esperar que el mismo Tribunal diga algo distinto en una opinión consultiva que en una demanda individual, al menos si no transcurre un lapso de tiempo suficiente para cambiar de criterio o para que cambie sustancialmente su composición. Desde el otro lado, tampoco parece muy probable que un tribunal nacional que solicita una opinión consultiva no se atenga a ella en su decisión final según ha razonado López Guerra. El Pleno del TEDH entendió esta falta de carácter vinculante como una invitación al diálogo judicial (Reflexión sobre la propuesta de extender la competencia consultiva, marzo de 2012, n. ${ }^{\circ}$ 3853038).

En efecto, de lo que se trata es que algunos altos órganos judiciales nacionales — los que cada país seleccione- interactúen con el TEDH, le exponga sus dudas y le den las claves nacionales antes de que el intérprete final acabe sentando una doctrina y unos estándares convencionales. Esta perspectiva, reforzar la subsidiariedad, se defendió en la Conferencia de Izmir y en la citada Reflexión del TEDH sobre la propuesta de extender la competencia consultiva, y se confirma en su posterior Opinión sobre el Protocolo 16, de 6 de mayo de 2013. Se excluye pues una cuestión «abstracta» de convencionalidad, carente de lo que en España llamamos suficiente juicio de relevancia para dictar el fallo de una sentencia. Quizás por eso —y también para desechar cuestiones notoriamente infundadas - el Protocolo 16 (artículo 2) dispone un trámite de inadmisión.

Recordemos que el artículo 4 bis. 2 de la Ley Orgánica del Poder Judicial establece que cuando los Tribunales decidan plantear una cuestión prejudicial europea lo harán de conformidad con la jurisprudencia del Tribunal de Justicia de la Unión Europea y, en todo caso, mediante auto, previa audiencia de las partes. Un recordatorio semejante habría que introducirse en la misma Ley para las nuevas opiniones consultivas ante el TEDH. Al tiempo, la Ley Orgánica del Poder Judicial debería cumplir el mandato del artículo 10 del Protocolo e indicar los órganos judiciales que designa como las más altas cortes a estos efectos. Se me ocurre que el Tribunal Supremo en cualquiera de sus Salas, la Audiencia Nacional y los Tribunales Superiores de Justicia. Ambas previsiones normativas podrían hacerse a la vez y en el mismo precepto.

¿Cuándo deberá el órgano judicial contentarse con hacer una interpretación conforme y cuándo debe inaplicar la ley nacional o plantear la cuestión de inconvencionalidad? Imagino deberá actuarse con la misma lógica que con la cuestión de inconstitucionalidad donde recordemos el artículo 5.3 de la Ley Orgánica del Poder Judicial, recogiendo jurisprudencia constitucional previa, establece que procederá el planteamiento de la cuestión de inconstitucionalidad cuando por vía interpretativa no 
sea posible la acomodación de la norma al ordenamiento constitucional. Será menester intentar primero una interpretación conforme y correctora, y, si no fuera posible, porque la literalidad de la ley lo impida, el juzgador deberá plantearse una opinión consultiva. Claro está que los órganos judiciales de instancia e intermedios, aquéllos que no sean las altas cortes, no podrán plantear esta cuestión de inconvencionalidad y podrían verse abocados a la inaplicación si alguna vez no bastara con una interpretación correctora. El resultado puede parecer paradójico.

En suma, puede en la práctica bastar con la interpretación correctora. Además, el espacio que resta a la inaplicación me parece que se verá reducido como consecuencia de este nuevo e interesante procedimiento de opiniones consultivas que otorga un carácter concentrado a la jurisdicción europea más que difuso. Me parece razonable que la ordenación de las jurisdicciones constitucionales y la del TEDH se asemejen, porque antes o después llegará una fusión de los controles de constitucionalidad y convencionalidad y debemos irnos preparando. Ese es el escenario futuro.

\section{LUIS JIMENA QUESADA}

Mi respuesta, en este caso, es tajante: entiendo que, en efecto, la Jurisdicción nacional tiene respaldo en nuestro ordenamiento constitucional para operar directamente ese control de convencionalidad difuso, sin necesidad de acudir a una cuestión de convencionalidad (concentrada ante el Tribunal Constitucional —entiendo-). Paso a razonar mi postura.

Tras cuatro décadas de vigencia de nuestra Constitución Española de 1978 (CE), parece extraño (de la propia pregunta así se desprende) que en la doctrina constitucionalista no se haya alcanzado todavía consenso en torno a la naturaleza supralegal de los tratados y a la inescindible consecuencia de llevar a la práctica (mediante el citado control de convencionalidad) dicho valor mediante la aplicación judicial de la norma internacional con desplazamiento de la norma nacional, señaladamente cuando la primera recoja un estándar más favorable. Cabalmente, el ordenamiento español ofrece bases constitucionales explícitas que dan indiscutible soporte al control de convencionalidad (y, por añadidura, a la efectividad de la tutela multinivel de los derechos), especialmente el mandato aplicativo de los tratados (arts. 93 a $96 \mathrm{CE}$ ) en conjunción con el mandato interpretativo (art. 10.2 CE). En este sentido, aunque la Carta Magna de 1978 no hable explícitamente de esa supralegalidad, de su art. 96 se deriva la superioridad y prevalencia de los tratados con respecto a la ley española y, sin duda, ese carácter supralegal se revela indiscutible cuando nos hallamos ante tratados sobre derechos humanos [art. 94.1.c) de la Carta Magna].

Es cierto que la Carta constitucional española de 1978 diverge de otras Constituciones extranjeras (particularmente, de la francesa vigente de 1958 - art. 55-) al no ser tan explícita al establecer la superioridad del tratado sobre la ley. No obstante, y sin que el debate constituyente permita desdecirlo, el texto final del art. 96 CE, como se decía, recoge esa superioridad aplicativa de los tratados sobre las leyes, en la línea de la Convención de Viena sobre el Derecho de los Tratados de 1969. Con tal filosofía, sobre no ser necesario, la Ley 25/2014, de 27 de noviembre, de Tratados y otros Acuerdos Internacionales viene a poner negro sobre blanco lo que dispone el reiterado art. $96 \mathrm{CE}$ al disponer explícitamente esa prevalencia (art. 31). La lógica argumentativa, recapitulando, es 
sencilla: si se reconoce la prevalencia del tratado sobre la ley, ¿puede tal afirmación quedar en una mera regla teórica? La respuesta sólo puede tener como consecuencia práctica que esa prevalencia comporta la aplicación judicial preferente del tratado sobre la ley.

A mayor abundamiento, y dejando de lado otras figuras afines al control de convencionalidad como la potestad de la jurisdicción ordinaria de pronunciar una extralimitación reglamentaria, la mayor afinidad viene dada por la lógica de los principios de primacía y efecto directo del Derecho de la UE. Si se tiene en mente ese sencillo paralelismo, quedarán superados los injustificados recelos dogmáticos a la asunción del control de convencionalidad operado por los órganos jurisdiccionales.

De análogo razonamiento se hizo eco, con gran acierto e inspirándose en la experiencia constitucional francesa, el Consejo de Estado español en su Memoria anual de 1997 (vid. pp. 147 y ss.), recordando que utiliza el doble control de constitucionalidad y de convencionalidad al dictaminar sobre los proyectos de ley. Así las cosas, si se aplica esa lógica argumentativa al terreno de la técnica legislativa (fase de elaboración de la norma), ¿qué impide trasladarla al campo de la praxis judicial (fase de aplicación de la norma)?

A mi entender, los argumentos tendentes a excluir el neto control difuso de convencionalidad de la esfera judicial ordinaria para reconducirla a la supervisión concentrada de la jurisdicción constitucional (mediante la cuestión de convencionalidad), parecen poco realistas y, sobre todo, se alejan del principal papel y mayor virtud del primer control, a saber, la efectividad de la tutela judicial de los derechos fundamentales en plazo razonable. Efectivamente, al margen de ese obstáculo principal consistente en diferir el control a sede jurisdiccional constitucional con la consiguiente demora, se presenta irrealista esa solución por implicar incluso un cambio de mentalidad que, hoy por hoy, no se atisba todavía en la Justicia constitucional española: por lo pronto, como es sabido, ésta ha rechazado incluir los tratados como parte del bloque de constitucionalidad al tiempo que, de facto, los ha utilizado aleatoriamente como tal parámetro (por todas, véase STC 236/2007, de 7 de noviembre, FFJJ 5 y 6).

Por lo demás, estimo innecesario que el TC efectúe el reconocimiento del control de convencionalidad a favor de la jurisdicción nacional, pues ya se desprende de la propia Carta Magna de 1978. Ahora bien, el aval del TC serviría ciertamente para apuntalar la convicción y la voluntad positiva de los órganos jurisdiccionales ordinarios. Por el contrario, a día de hoy, no se vislumbra ese aval, hasta tal punto que podría argüirse que la Corte Constitucional española, en materia de control de convencionalidad, ni hace ni deja hacer, como se ha criticado en el seno del propio Tribunal.

Así, gran interés despierta el voto particular concurrente de Juan Antonio Xiol Ríos (al que se adhieren Adela Asua Batarrita y Fernando Valdés Dal-Ré) formulado a la STC 270/2015, de 17 de diciembre, en donde se afirma que la cuestión del control de convencionalidad «debería ser sometida a una reconsideración más profunda por este Tribunal para evitar determinadas situaciones paradójicas que se plantean en el ordenamiento jurídico español» y con respecto a lo cual «este Tribunal, como máximo intérprete de la Constitución, deberá pronunciarse más fundadamente en algún momento». Y se recapitula así la crítica a esa elusión del control de convencionalidad: «La actual jurisprudencia parece que aboca a que sólo se posibilite el desarrollo de ese control de convencionalidad de manera concreta por parte de los órganos judiciales cuando deba aplicarse la ley que se estime contraria a un tratado internacional a partir de considerarlo una mera cuestión de selección normativa, lo que, en su caso, podría ser impugnado en amparo por la vía del 
artículo 24.1 de la Constitución española en caso de arbitrariedad o irrazonabilidad. No deja de resultar paradójico que en el contexto de una creciente propensión al control abstracto de normas con fundamento en razones de seguridad jurídica, el único control abstracto que quede ayuno de cualquier vía de planteamiento sea el control de convencionalidad de las normas con rango de ley que, si no puede ser ejercido por la jurisdicción ordinaria, tampoco este Tribunal está posibilitando que se ejerza a través del recurso de inconstitucionalidad o la cuestión de inconstitucionalidad por la vía de la invocación de los artículos 9.1 o 96 de la Constitución española».

Desde este punto de vista, los recelos dogmáticos (y jurisdiccionales) se presentan tanto más injustificados cuanto que, en la praxis (y el cómputo no puede ser estadísticamente más sencillo, por su carácter excepcional), el ejercicio responsable del control de convencionalidad se operará en supuestos aislados en los que la norma internacional (y, sobre todo, la jurisprudencia internacional correspondiente) ofrezcan claridad y certeza en cuanto al supuesto controvertido. A este respecto, la contrariedad no se verificará abiertamente entre la ley y el tratado (por la existencia de un control de convencionalidad previo de la ley - por ejemplo, el ya citado de los proyectos de ley ante el Consejo de Estado- y de un posible control preventivo de constitucionalidad de los propios Tratados), sino entre la ley (y su interpretación jurisprudencial interna) y la interpretación del Derecho comunitario europeo, susceptible de provocar inseguridad jurídica y violación de derechos, cuyo remedio o corrección ante el TC ha venido de la mano del derecho a la tutela judicial efectiva del art. 24.1 CE (por todas, STC 64/1991, de 22 de marzo). Y, con claro agravio con respecto al control de convencionalidad, no se pone en entredicho el juego de esos principios de primacía y efecto directo del Derecho de la UE que, al contrario, se han saludado con entusiasmo.

\section{CARLOS RUIZ MIGUEL}

Para resolver esta cuestión debemos partir de tres datos normativos y de un principio de teoría del Derecho. Los datos normativos son los siguientes. El primero es que, de acuerdo con la Constitución el Tratado es una norma superior a la ley pues tiene fuerza activa (art. 94.1 CE) y fuerza pasiva (art. $96 \mathrm{CE}$ ) frente a ella. El segundo dato es que los jueces y tribunales ordinarios están sometidos al imperio de la ley (art. 117.1 CE) y al resto del ordenamiento jurídico (art. 9.1 CE), pero sólo pueden «controlar» la potestad reglamentaria (art. 106.1 CE), no la potestad legislativa. Y el tercero es que al Tribunal Constitucional no se le ha asignado (aunque hubiera podido hacerse) la tarea de controlar la conformidad de la ley con los tratados. Por su parte, el principio de teoría del Derecho es el de distinguir la «validez» de la «eficacia» de las normas. Partiendo de lo anterior, ¿quién debe garantizar que la ley no sea contraria a los tratados?

De lege ferenda, sería perfectamente posible atribuir al Tribunal Constitucional (art. 161.1.d CE) la competencia para conocer de una «cuestión de convencionalidad» cuando un juez estime que una ley aplicable al caso sea contraria a un tratado internacional. Es ya una decisión política en la que no voy a entrar la de determinar qué es mejor, si atribuir la resolución del problema a los tribunales ordinarios para decidir en función de la «eficacia» de las normas o atribuirla al Tribunal Constitucional para que resuelva determinando la «validez» de las normas. Por lo que respecta al TEDH, como es sabido, no 
tiene competencia ni para determinar la «validez» de las normas españolas (aunque contradigan al CEDH) ni para decidir sobre su «eficacia» en el ordenamiento español. Para que pudiera hacer alguna de estas cosas sus sentencias deberían gozar de fuerza ejecutiva atribuida por el propio $\mathrm{CEDH}$, pero no parece que se quiera modificar el Convenio para incluir este aspecto. En este momento, en España, las leyes orgánicas 7/2015 y 41/2015 permiten introducir un recurso de revisión cuando una sentencia del TEDH haya declarado una violación de un derecho reconocido en el $\mathrm{CEDH}$ pero, precisamente por eso, quien decide finalmente sobre la «eficacia», como se dirá a continuación, son los tribunales españoles.

De lege lata, si analizamos la cuestión desde la perspectiva de la «validez» hay dos cosas claras. En primer lugar, la «validez» de un tratado no puede juzgarse por un juez ordinario. En segundo lugar, esa «validez» pudiera ser examinada por el Tribunal Constitucional, ciertamente, pero sólo cuando el tratado es contrario a la Constitución. Sólo en este último caso un juez ordinario podría plantear una «cuestión de inconstitucionalidad».

Pero el problema de la eventual incompatibilidad de una ley con un tratado, cuando tanto el tratado como la ley sean conformes con la Constitución, se puede solucionar desde la perspectiva de la «eficacia». Los jueces ordinarios tienen el deber de aplicar el Derecho vigente en nuestro Ordenamiento jurídico. En ese caso, cuando dos normas están vigentes, pero hay una contradicción entre ellas, y no es posible anular la «validez» de una de ellas, el juez debe dar «eficacia» a aquella que sea superior, en este caso, el tratado internacional. Esta fórmula no cambiaría ni siquiera en el caso de que España llegara a ratificar el Protocolo número 16 (firmado el 2 de octubre de 2013 y en vigor para varios Estados desde el 1 de agosto de $2018^{3}$, pero no ratificado por España), que introduce en el CEDH la «cuestión de convencionalidad» por vía consultiva. Esto es así porque la consulta al TEDH acerca de la eventual incompatibilidad de una ley con el CEDH no es vinculante.

\section{ROSARIO TUR AUSINA}

El especial valor interpretativo de los Tratados en materia de derechos fundamentales ex art. 10.2 CE coloca a aquellos en una singular posición en el ordenamiento. En virtud del efecto irradiación de la Constitución y en armonía con ésta, los Tratados son - por mandato constitucional — una especie de prolongación de aquella en materia de derechos, con una naturaleza quasiconstitucional que difumina la jerarquía entre ambas normas. Por ello, cualquier operador jurídico está naturalmente obligado a aplicar y verificar el cumplimiento de este marco constitucional complejo que pretende construir un ius comune para la vigencia efectiva de los derechos. La cuestión no es entonces si se acepta o no en nuestro Estado el control de convencionalidad, ya que el art. 10.2 CE es rotundo, sino el modo en que se ejerce aquél, teniendo en cuenta que dicho control puede ser externo — por el TEDH - e interno — por las jurisdicciones nacionales_- ; así como concreto — frente a actos lesivos-, y abstracto — cuando una disposición general interna

3 Los Estados que lo han ratificado y para los que está en vigor desde el 1 de agosto de 2018 son: Albania, Armenia, Eslovenia, Estonia, Finlandia, Francia, Georgia, Lituania, San Marino y Ucrania (datos a 13 de junio de 2018). 
contradice un Tratado-. La clave es determinar el margen de maniobra y delimitación de competencias entre las diversas instancias implicadas.

De este modo, las jurisdicciones nacionales deben llevar a cabo su propio control de convencionalidad, que implica, simple y llanamente, la aplicación del ordenamiento supranacional de los derechos, la definición de los mismos, y las consecuencias jurídicas necesarias para aquellos actos o disposiciones que lo contravengan; todo ello en el marco de sus propias competencias y de los procedimientos correspondientes. Pero la pregunta se centra, más bien, en el denominado control abstracto de convencionalidad, esto es, en el ajuste de la norma interna a un Tratado. Un control que es fundamentalmente externo y que se ejerce por las instancias supranacionales — por el TEDH en concreto, pero también por el Comité Europeo de Derechos Sociales, la institución olvidada-, de modo similar al ejercicio de control de constitucionalidad interno, pero sin fuerza ejecutiva y, en consecuencia, sin la capacidad para decidir la nulidad de la disposición controvertida, aunque la misma puede ser sugerida o recomendada. El TEDH actuaría a modo de jurisdicción concentrada aunque no absoluta, pues el Convenio se articula sobre la idea del principio de subsidiariedad, es decir, dejando espacio a las instancias nacionales para que ejerzan como garantes prioritarios del sistema multinivel de derechos.

Pero lo anterior, en un sistema multinivel, se encaja con un control de convencionalidad abstracto de carácter interno, es decir por la justicia nacional, que podrá articularse diversamente dependiendo de la organización de la jurisdicción ordinaria y constitucional de cada país, con la determinación del específico margen de maniobra de estos respecto a la capacidad de verificación del cumplimiento de los Tratados frente a una contradicción manifiesta con una norma nacional. Esto significa que la configuración del control de convencionalidad se va a reconducir en principio en nuestro país al modelo predominantemente concentrado, aunque se observan, como veremos y es propio de nuestro sistema, importantes rasgos difusos que plantean no pocas dudas y problemas.

En cualquier caso, el diálogo se produce en dos niveles. Entre las instancias nacionales: justicia ordinaria y constitucional. Y, en segundo lugar, entre las instancias nacionales y la supranacional, posibilidad que se abre con el Protocolo n. ${ }^{\circ} 16$ - pendiente de firma y ratificación por España-, y que permite dirigir al TEDH solicitudes de opiniones consultivas sobre cuestiones de principio relativas a la interpretación o aplicación de los derechos garantizados por el Convenio y sus Protocolos. Armar ese triple nivel es necesario para el funcionamiento armónico y coherente del sistema, lo que exige responder a la capacidad de maniobra de la justicia ordinaria y la constitucional para resolver por sí mismas la inaplicación/nulidad de la norma interna, o elevar una cuestión de inconstitucionalidad/convencionalidad al órgano correspondiente.

En esta articulación es determinante, en primer lugar, el rol del TC. Y partimos para ello de su posicionamiento respecto a la integración de los Tratados en el canon de constitucionalidad, pues el mismo ha constituido a nuestro juicio un cierto escollo al uso de la cuestión de convencionalidad ante el TEDH. En efecto, son conocidas las reticencias mostradas por nuestro TC para convertir a los Tratados en canon autónomo de validez, siendo todo lo más canon interpretativo, pues el parámetro de constitucionalidad, nos dice, está integrado «por el precepto constitucional definido del derecho o libertad, si bien interpretado, en cuanto a los perfiles exactos de su contenido, de conformidad con el tratado o acuerdo internacional, todo ello en virtud de lo establecido en el art. 10.2 CE» (SSTC 28/1991, 236/2007). Así, de ello derivan dos consecuencias: 1) para el 
Tribunal el control de convencionalidad no posee autonomía constitucional propia, sino que aquel es un elemento de apoyo en el clásico control de constitucionalidad, que se usa en colaboración con la definición y la interpretación interna de los derechos constitucionales; y 2) si esto es así, es difícil que el TC se plantee elevar una cuestión de convencionalidad a una jurisdicción supranacional - la cual actúa llevando a cabo un contraste entre el Tratado correspondiente y la norma interna-, pues simple y llanamente ello significaría aceptar el posible canon autónomo de validez de aquellos y con ello la pérdida del derecho a la última palabra que el TC parece arrogarse con esta controvertida doctrina sobre el canon autónomo/interpretativo.

$\mathrm{Y}$ es que deben superarse tales planteamientos y recordar que el constitucionalismo multinivel se articula sobre la convivencia y colaboración de una pluralidad de ordenamientos interconectados, donde el eje —que no protagonista único- sigue siendo el Estado. Y todo ello al margen de que la receptividad del TC al derecho supranacional sea más intensa respecto al TEDH, y menos respecto al Comité Europeo de Derechos Sociales o a otras instancias.

La doctrina sobre el canon autónomo/interpretativo despierta controversias y no está unánimemente aceptada. Pero en nuestra opinión dicha doctrina no puede imponerse al principio pro persona, pues la entidad propia del art. 10.2 CE se traduce en la obligación para cualquier operador jurídico de buscar y argumentar sobre la interpretación más favorable a los derechos, el estándar más elevado, a partir del tándem Constitución-Tratados, según corresponda. Al fin y al cabo la distinción canon autónomo/canon interpretativo no deja de ser un criterio hermenéutico elaborado por el propio TC, a diferencia del principio pro persona, que deriva directamente del art. $10 \mathrm{CE}$. Si el canon europeo es un canon constitucional ningún sentido tiene, pues, dotarlo o no de carácter autónomo o interpretativo. Sencillamente, ello dependerá de la configuración particular y concreta del estándar de cada derecho.

Con la posible elevación por el TC de una cuestión de convencionalidad se está admitiendo, precisamente, la concesión de un valor constitucional al Convenio, y se muestra la confianza en el TEDH, que al fin y al cabo es el intérprete auténtico — que no el único- de dicho Convenio. Significa ello aceptar una voz más autorizada, que posee auctoritas y que es suficientemente considerada, al objeto de retroalimentar la decisión constitucional, en quien queda la articulación definitiva de la resolución final al litigio, respondiendo así a la plena vigencia del principio de subsidiariedad y al principio de lealtad constitucional multinivel. Además, de esta forma — pero esto ya es un efecto secundario-, se evita que con posterioridad el TEDH recomiende al Estado la nulidad de la disposición contraria al Convenio. Sólo así se entienden los Protocolos 15 y 16. Uno como reverso del otro. Se da un protagonismo a los Estados ofreciéndoles la capacidad de dialogar — previamente a la resolución final— con la jurisdicción de Estrasburgo, desde la más pura aplicación de la teoría de los vasos comunicantes en ciencia sociales, según la cual las diferencias físicas y temporales pueden ser salvadas cuando dos grupos o entes que comparten un mismo objetivo encuentran los mecanismos necesarios para entrar en contacto, de tal modo que así uno se pueda ver influenciado por el otro e incrementen ambos la comprensión del tema en cuestión.

La cuestión de convencionalidad encaja, pues, en la filosofía general del Convenio de Roma de dar la oportunidad a los Estados de construir un estándar constitucional complejo de derechos desde sus mismas instancias nacionales. Por lo demás, la previsión de 
una cuestión de convencionalidad resulta especialmente aconsejable en países con tradición de control de constitucionalidad concentrado - aunque no puro- como el nuestro, donde aún se necesita reforzar el manejo del derecho supranacional de los derechos humanos, y puesto que con ello se crea un contrapeso importante respecto a los recurrentes riesgos de dependencia política de la jurisdicción constitucional (Ramírez, «El control judicial interno de convencionalidad», Ius, 2011). Pero además, finalmente, es también recomendable para evitar los ulteriores puenteos por parte de la jurisdicción ordinaria.

Precisamente esta última idea nos introduce en el tema del diálogo de la justicia ordinaria con la constitucional, pues hemos asistido a una complicada y oscilante aplicación del control de convencionalidad por parte de la primera. El problema se ha producido cuando, en ese puenteo que citamos, los Tribunales ordinarios han aplicado de modo preferente Tratados —o la jurisprudencia emanada de ciertos organismos supranacionales - que entran en contradicción con la ley española (y/o la doctrina del TC emitida al respecto), evitando elevar una cuestión ante el TC (como ejemplos, los casos de la legislación sobre la reforma laboral de 2012, o sobre las prestaciones sanitarias a inmigrantes irregulares del mismo año). Aunque es cierto que esta dinámica ha sido especialmente acusada a raíz de las medidas anticrisis y los pronunciamientos de distintas instancias supranacionales, también se ha observado paradójicamente la actitud contraria, pues aun existiendo condenas por parte de organismos supranacionales, la justicia ordinaria se ha dejado llevar por su dependencia excesiva de la doctrina del Tribunal Constitucional (ex art. 5.1 LOPJ), de tal modo que solo incorporan las obligaciones internacionales a través de su doctrina, sin aplicarlas directamente ni cuestionar tampoco la norma nacional a través de la cuestión interna de convencionalidad (Jimena, Jurisdicción nacional y control de convencionalidad, 2013). Un problema que no se da en el caso del derecho de la Unión Europea y respecto a la doctrina de Luxemburgo, pues este prima y tiene efecto directo sobre el derecho interno, de tal modo que la justicia ordinaria no necesita del rol de intermediario del Tribunal Constitucional.

Ante esta situación se trata, efectivamente, de abordar importantes retos. Por un lado, en lo que atañe al TC, parece oportuno incorporar la cuestión de convencionalidad, que debería acompañarse de un liderazgo — que no monopolio- más fuerte. Una instancia que debería asumir que existen más órganos de vigilancia constitucional, ejercer un contacto más interactivo (evitando citas superficiales de la doctrina de Tribunales supranacionales pero también la mera omisión), y reformular la polémica distinción canon autónomo/canon interpretativo de los Tratados para anteponer el principio pro persona. Y ello porque está más que demostrado en el funcionamiento de los sistemas políticos que actitudes y prácticas que fomentan la deslealtad y una cierta dejación de funciones no hacen más que desequilibrar aquellos, acentuando un activismo no deseado — ni plenamente legítimo - de otras instancias. Se necesita que el TC asuma como propio — por haber contribuido a construirlo- el acervo europeo, lo conozca, lo entienda y lo integre siempre desde el principio de subsidiariedad y de la idea del estándar más alto de tutela, que no siempre es el definido por el TEDH. El TC puede ser un buen órgano para la unificación y el diálogo con la instancia supranacional, pero ello no debe restar espacio a la justicia ordinaria, cuyo papel no es poco relevante, aunque se necesiten también profundos cambios de cultura constitucional multinivel.

Por otro lado, en segundo lugar y respecto a la justicia ordinaria, si el control de convencionalidad se integra en el más amplio concepto del control de constitucionalidad, es problemático depositar en aquella la capacidad para inaplicar normas inconvencionales, 
pues esto dificultaría la armonía de la jurisprudencia y además es poco acorde a nuestro modelo predominantemente concentrado aunque no puro. Lo más procedente es el planteamiento de la cuestión interna de convencionalidad ante el TC, evitando así las soluciones judiciales discrepantes. Lo cual exige, por cierto, fuertes dosis de formación/información en el constitucionalismo multinivel europeo de los derechos. Además, aunque se puede pensar en el planteamiento directo de una cuestión de convencionalidad por parte de la justicia ordinaria y ante el TEDH, creemos que esta opción no encaja bien con el carácter subsidiario del Convenio, que obliga a que, antes de buscar el diálogo con la instancia supranacional, se agoten las posibilidades internas.

De esta forma, se intenta armar el sistema de instrumentos cooperativos en el sentido expuesto para evitar, precisamente, actitudes problemáticas y no deseables como la inaplicabilidad de facto por la justicia ordinaria de normas inconvencionales. Una actitud esta última — la inaplicación- que, no obstante, creemos necesaria y plenamente legítima, cuando ha habido antes una primera decisión del TC, ha existido la posibilidad de usar la cuestión de convencionalidad ante Estrasburgo por aquel y no se ha hecho, y con posterioridad su resolución ha sido rebatida por la instancia supranacional. Se le da de este modo el adecuado protagonismo a la justicia ordinaria, y se permite que la ciudadanía pueda acceder a una aplicación efectiva última del derecho convencional; posibilidad que operaría, no obstante, sólo en último término. Porque aunque es positivo — como en el caso de las prestaciones sanitarias para la población inmigrante- que nuestro sistema político haya encontrado a veces los cauces para hacer realidad el control de convencionalidad y la Europa de los Derechos, se trata de evitar estas prácticas asimétricas, que siguen generando sin embargo desigualdades —en tanto las prestaciones solo se concedieron judicialmente de forma puntual o en determinadas Comunidades Autónomasno permitiendo consolidar una extensión generalizada de determinados derechos a toda la ciudadanía, como obviamente es deseable en cualquier sistema constitucional.

Procedimentalmente, para articular la cuestión interna de convencionalidad, pensamos que no se necesitaría en principio la modificación de la Ley Orgánica del Tribunal Constitucional, pues en el concepto de Constitución a que alude el art. 163 CE se encuentran también, en virtud del art. 10.2 CE, los Tratados. Y tampoco para reflejar la cuestión externa de convencionalidad, que viene asumida por el Estado en virtud de la firma y ratificación del Protocolo pertinente. No obstante, es cierto que una reforma de dicha Ley Orgánica clarificaría este aspecto y ejercería una fuerte labor pedagógica, reforzando la seguridad jurídica en una cuestión que doctrinal y políticamente puede ser todavía controvertida y tiene contornos imprecisos.

Tenemos delante importantes retos que obligan a mostrar ciertas cautelas y tomar ciertas medidas. Por un lado, el mencionado refuerzo de la formación de la justicia ordinaria en el constitucionalismo multinivel de los derechos, con su propio espacio para integrar el acervo supranacional, de tal modo que el planteamiento de la cuestión de convencionalidad tenga lugar sólo cuando la contradicción sea manifiesta e insalvable por la vía de la interpretación. Pero al mismo tiempo, no olvidemos que los clásicos problemas de dependencia política de la justicia constitucional hacen también aquí acto de presencia, necesitándose que el propio TC entre en una conexión más intensa con el constitucionalismo multinivel, para evitar precisamente la idea del monopolio de un solo Tribunal encerrado en la política doméstica y mediado por los designios de las fuerzas parlamentarias y por coyunturas políticas concretas. 
Debe recordarse, aun siendo obvio, que no se parte de la unidad, sino que se pretende una aproximación constante a ella a través de una síntesis precaria entre lo que nos une y lo que nos distancia, superando modos sofistas que implican un convencer para vencer, y que tienden a hacer un uso interesado del diálogo para legitimar lo ya previamente decidido, o para evitar decidir resultando preferible que lo decida otro. Por el contrario, lo complicado pero auténtico, es asumir los modos socráticos, con formas y maneras amables y pedagógicas, de interactuar, producir ideas y generar verdades indivisibles, buscando normas o decisiones que unifican a través de un proceso de retroalimentación abierto (Lüther, «Jueces europeos y jueces nacionales: la Constitución del diálogo», RDCEur, 2005).

3. ¿Qué querría decirnos sobre la interpretación dinámica o evolutiva del TEDH? ¿Cómo valora tal jurisprudencia? ¿Puede, en su opinión, ser compatible con la seguridad juridica y con los límites en la actividad interpretativa y aplicativa de los jueces?

\section{ENOCH ALBERTÍ ROVIRA}

El CEDH es un tratado internacional, pero un tratado que, por el hecho de que reconoce determinados derechos y libertades a las personas y establece, además, un mecanismo jurisdiccional de protección individual de los mismos frente a los propios Estados signatarios, presenta algunas características especiales. Entre ellas, por lo que ahora interesa, las relativas a su interpretación.

Porque, en efecto, la interpretación de los tratados internacionales se rige por unas reglas específicas, codificadas en la Convención de Viena sobre el derecho de tratados de 1969. Estas reglas, previstas básicamente en los artículos 31 y 32 de la Convención, son, ciertamente, generales y a su vez interpretables. Pero forman unas reglas específicas que deben ser aplicadas, dentro de los márgenes admisibles, para interpretar legítimamente los tratados y, por tanto, las obligaciones que contraen los Estados a través de los mismos, con la finalidad básica, por lo que aquí interesa, de evitar una expansión de las obligaciones de los Estados contenidas en los tratados. La interpretación, en suma, no puede convertirse en un instrumento para que un Estado pueda verse obligado más allá de lo que consintió al celebrar un determinado tratado.

En cuanto el CEDH es un tratado internacional, celebrado por un conjunto de Estados, por medio del cual se reconocen a las personas determinados derechos frente a los mismos y se crea, además, un instrumento de protección jurisdiccional de las personas frente a los propios Estados signatarios, aparece naturalmente una tensión entre dos polos con exigencias opuestas: por una parte, la tendencia evolutiva de los derechos fundamentales, que deben amoldarse a los nuevos tiempos y circunstancias de un mundo en constantes y aceleradas transformaciones; y, por otra, la resistencia de los Estados a asumir, por vía interpretativa, nuevas obligaciones no consentidas expresamente. Desde su posición, obvia también desde su perspectiva de sujetos del derecho internacional, si hay que producir cambios o introducir modificaciones, la vía natural y adecuada es la modificación del Convenio.

Sin embargo, como se ha dicho, una interpretación evolutiva o dinámica es inevitable en materia de derechos fundamentales, que podrían quedar en gran parte 
obsoletos y sin eficacia protectora real en caso contrario. Por ello, el TEDH no ha podido sino asumir una interpretación de este carácter, considerando el Convenio como un organismo vivo, según su propia y conocida expresión. Y, al hacerlo, se aparta inevitablemente de los medios clásicos de interpretación previstos en la Convención de Viena, pues no es reconducible en realidad a ninguno de los allí establecidos, aunque a veces quiera apoyarse en la «práctica ulteriormente seguida en la aplicación del tratado por la cual conste el acuerdo de las partes acerca de la interpretación del tratado» (art. 31.2.b), apoyatura claramente insuficiente por la sencilla razón de que el TEDH no hace depender su interpretación, exclusivamente, del acuerdo de todos los Estados, ni exige que la nueva interpretación se haya expresado a través de una práctica común o acordada. De este modo, hay numerosos casos de interpretación dinámica, que suponen una evolución del ámbito, el contenido o los límites de los derechos reconocidos en el $\mathrm{CEDH}$, como ocurre por ejemplo en materia de privacidad, donde resulta obvio que se han producido cambios notables desde la entrada en vigor del Convenio. Ello resulta inevitable, y es común que ocurra en las jurisdicciones de protección de derechos: la jurisprudencia de los altos tribunales, y de forma especial de los tribunales constitucionales en los sistemas de justicia constitucional concentrada y de los tribunales supremos en los de carácter difuso, como se puede acreditar también mediante numerosos ejemplos, constituye una vía normalizada de evolución, esto es, de introducción de cambios y modificaciones en materia de derechos y libertades. En el ámbito del TEDH, y en tanto que el CEDH es un tratado internacional, los cambios deberían producirse fundamentalmente mediante la modificación del propio Convenio (incluyendo, naturalmente, la adición de protocolos complementarios). Y ello es así, como prueba el número notable de protocolos añadidos que han afectado el texto del Convenio. Pero también se han producido cambios notables por vía interpretativa, a semejanza en gran parte de lo que ocurre con los tribunales constitucionales. Y estos cambios no son de carácter menor, afectando sólo algunos elementos de los derechos reconocidos, sino que han alcanzado también al texto explícito del Convenio, en aspectos además sustanciales y nucleares del mismo, cambiando notablemente su sentido y el modo en que había sido entendido hasta un momento determinado. Creo que esta circunstancia $-\mathrm{y}$ la mera posibilidad de que se produzca y, además, sea aceptada, con mayor o menor agrado, por los Estados parte- supone un salto cualitativo en la protección de los derechos dispensada por un organismo internacional, que lo acerca a los altos tribunales de los Estados supremos en materia de derechos fundamentales. Y ello, que fuerza el Derecho internacional y conlleva tensiones, es un síntoma del afianzamiento del espacio europeo de los derechos, labor a la que ha contribuido de forma decisiva precisamente el hecho de que se haya creado un mecanismo jurisdiccional de protección individual y directa de los derechos, de carácter autónomo. La revisión del CEDH, con la adopción de nuevos protocolos, sigue siendo la vía principal de evolución de la protección de los derechos en el ámbito europeo, como no podía ser de otro modo en atención a la naturaleza internacional del mecanismo creado, pero ésta ya no es la única vía posible, sino que, junto a ella, y de forma muy notable, actúa también la jurisprudencia del propio TEDH como vía de evolución, adaptación y cambio, al margen, y a veces incluso en contra, de su texto. El avance de la protección de los derechos en Europa no depende sólo de la voluntad de los Estados, sino también del órgano, autónomo, que ellos han creado para este fin. 
Creo que es ilustrativo de ello el tratamiento de la pena de muerte por parte del TEDH y su evolución. Como se sabe, en 1989 el TEDH aceptó que el derecho a no sufrir tratos inhumanos o degradantes que reconoce el art. $3 \mathrm{CEDH}$ no suprimía la excepción a la prohibición de la pena de muerte que establece el segundo inciso del art. 2 CEDH (Sentencia Soering v. RU, 1989). Sin embargo, unos años después (Sentencia Öcalan v. Turquía, 2005), y a pesar de que se hallaba aún en proceso de ratificación el Protocolo n.6, por el que se abolía la pena de muerte en tiempos de paz (proceso en el que faltaban aún tres Estados por ratificar), el TEDH considera que la pena de muerte se ha convertido en una sanción inadmisible y que, por tanto, debe entenderse derogado, o cuando menos modificado, el segundo inciso del art. 2.1 CEDH, que admite la pena de muerte en tiempos de paz. Ciertamente, puede entenderse que el razonamiento del Tribunal puede ampararse en el medio de interpretación del art. 31.3.b (práctica de los Estados), pero también es cierto que no todos los Estados parte habían ratificado el Protocolo (si fuera así, el problema de interpretación simplemente desaparecería) y que el propio Tribunal alude expresamente a su doctrina del CEDH como instrumento vivo, que debe ser interpretado a la luz de las condiciones de vida actuales y a un nivel de exigencia mayor en el respeto de los derechos fundamentales. La concepción de lo que sean penas inhumanas y degradantes, dice el TEDH, ha evolucionado desde la entrada en vigor del Convenio, y también desde 1989, año de la Sentencia Soering. Un claro ejemplo de interpretación evolutiva, con efectos expansivos de los derechos y, consecuentemente, limitativos de la acción de los Estados, más allá de las obligaciones explícitamente contraídas mediante el Convenio. Al menos, claro está, para los tres Estados que aún no habían ratificado el Protocolo n. ${ }^{\circ} 6$, entre los que se encontraba precisamente el demandado en el caso Öcalan. Que después la decisión del Tribunal se basara también en la vulneración de las garantías procesales y del derecho a un juicio justo que consagra el CEDH (pues la pena de muerte en todo caso debe imponerse en virtud de un proceso judicial, como establece expresamente el art. 2.1 CEDH, y en este proceso, dice el Tribunal, deben maximizarse las garantías judiciales y legales, pues en caso contrario se estaría también ante un trato inhumano o degradante, por las circunstancias especiales que concurren en un proceso donde se puede imponer la pena de muerte) no empaña la importancia ni la trascendencia de este tipo de interpretación del Convenio.

\section{JUAN MARÍA BILBAO UBILLOS}

Un tribunal no puede operar de espaldas a una realidad que cambia incesantemente y cada vez de forma más acelerada. Todos sabemos lo que dice al respecto nuestro Código Civil en su artículo 3.1: «las normas se interpretarán según el sentido propio de sus palabras, en relación con el contexto... y la realidad social del tiempo en que han de ser aplicadas». En la jurisprudencia del Tribunal Constitucional resulta emblemática en este sentido la Sentencia 198/2012, de 6 de noviembre, que desestimó el recurso contra la Ley 13/2005, de 1 de julio, por la que modificó el Código civil en materia de derecho a contraer matrimonio. En dicha sentencia, como es sabido, se aboga por una «interpretación evolutiva» (FJ 9) de la institución del matrimonio que la Constitución garantiza, una sincronización o puesta al día que encuentra un límite 
infranqueable en el propio tenor literal de la norma, porque no se puede hacer decir a ésta lo que manifiestamente no dice. En la jurisprudencia norteamericana o canadiense es moneda corriente la referencia a la Constitución como un árbol vivo que se acomoda a los nuevos tiempos mediante una lectura evolutiva. Sin esa constante actualización acabaría siendo letra muerta. Y no faltan ejemplos en la ingente jurisprudencia del TEDH de esa interpretación evolutiva que trata de renovar el significado del texto al ritmo de las transformaciones sociales y los constantes cambios que se producen en la conciencia colectiva, en la percepción o valoración social de determinados comportamientos y en la propia cultura jurídica. Una interpretación dinámica y creativa asociada casi siempre a la incontenible fuerza expansiva de los derechos e inspirada en el principio favor libertatis, que se traduce en el reconocimiento jurisprudencial de nuevos derechos o en la ampliación del perímetro o el contenido de los derechos ya consagrados, de las situaciones jurídicas tuteladas por el mismo.

Es verdad que el Convenio, una declaración fechada en 1950 que sólo proclamaba derechos civiles formulados como libertades negativas y no incluía derechos de prestación ni otros de tercera o cuarta generación, se ha ido completando con algunos Protocolos que han incorporado sucesivamente derechos no contemplados en su redacción originaria o han reforzado su protección (como los Protocolos n. ${ }^{\circ} 6$ y 13 en relación con la abolición de la pena de muerte, una pena que en 1950 figuraba aún como castigo por determinados delitos en bastantes ordenamientos europeos), pero la necesaria adaptación a las nuevas realidades se viene haciendo sobre todo por vía interpretativa. El propio Tribunal asumió desde el principio que el Convenio es un «instrumento vivo» que debe interpretarse a la luz de las circunstancias de cada momento, descartando la alternativa de una lectura «originalista», que girase en torno a la voluntad auténtica de sus redactores y a los trabajos preparatorios. Una interpretación «estática», que no se acomodase a la realidad que pretende regular el Convenio, acabaría por degradar su eficacia normativa. No se puede mantener, por ejemplo, un concepto tradicional de «esclavitud» (estado o condición de una persona sobre la cual se ejercitan algunas de las facultades propias del derecho de propiedad, según la Convención de 1926) o «trabajo forzado» (que el art. 4 CEDH prohíbe tajantemente) cuando en la actualidad esa relación de servidumbre aparece camuflada o encubierta bajo otras formas (Siliadin c. Francia, 2005). No creo que esa actualización ponga en riesgo la seguridad jurídica o represente una extralimitación por parte del Tribunal. Todo lo contrario, me parece obligada.

Resulta paradigmática en este sentido la jurisprudencia relativa al derecho a la vida privada consagrado en el art. 8 del Convenio. De este precepto ha extraído el Tribunal normas o significados insospechados. Hay que reconocer que la noción de vida privada y familiar es especialmente versátil y polisémica, pero se ha convertido en un «cajón de sastre» en el que cabe prácticamente todo. Quizá sea éste el único terreno en el que pueden cuestionarse algunos hallazgos jurisprudenciales.

Así, su ámbito de protección se ha extendido, por ejemplo, a los procedimientos de expulsión en su vertiente de vida familiar; y a las intromisiones causadas por agentes medioambientales, como el ruido, ante la ausencia de un derecho a disfrutar de un medio ambiente saludable en el Convenio. En efecto, el Tribunal de Estrasburgo viene reconociendo desde hace tiempo la posibilidad de que este derecho pueda ser conculcado por agentes medioambientales (molestias como ruidos y olores esencialmente) si concurren una serie de circunstancias. Según el TEDH, la persona tiene derecho a que se respete su 
domicilio, concebido no solamente como el derecho a un espacio físico concreto en el que se desarrolla la vida privada y familiar, sino también el derecho al disfrute, con toda tranquilidad, de dicho espacio.

En esta misma línea de ampliar las obligaciones positivas de los Estados que se derivan del reconocimiento de determinados derechos, una aportación de gran calado es la exigencia de investigación de las denuncias de tortura y otros malos tratos a manos de funcionarios encargados de hacer cumplir la ley. Mediante la incorporación de esta dimensión «procesal» de la prohibición establecida en el art. $3 \mathrm{CEDH}$, se trata de garantizar que las denuncias se investigan de manera independiente, exhaustiva e imparcial, que los responsables comparecen ante la justicia y que las víctimas de esos malos tratos reciben el resarcimiento adecuado. Conviene recordar que en el período 2010-2016 el Tribunal de Estrasburgo ha condenado a España en ocho ocasiones por insuficiente investigación de las denuncias formuladas por los demandantes, en casi todos los casos detenidos sometidos a un régimen de incomunicación.

Otro ejemplo de interpretación evolutiva en relación con este mismo precepto es la sentencia dictada en el caso Selmouni c. Francia (1999), que precisó que ciertos actos que han sido calificados en el pasado como «trato inhumano o degradante» podrían ser calificados de forma diferente en el futuro, «pues el incremento del estándar de protección de los derechos humanos y libertades fundamentales requiere inevitablemente impedir las violaciones de los valores de las sociedades democráticas». Y efectivamente en la actualidad si el TEDH aprecia que los malos tratos infligidos han sido severos y crueles y, en ocasiones, también prolongados, califica dichos actos como torturas, aunque la finalidad perseguida por el maltrato no haya sido el obtener una confesión o información. También supuso un punto de inflexión en la interpretación de esta prohibición la decisión adoptada en el asunto Soering c. Reino Unido (1989), en la que el TEDH estableció la obligación de no extraditar cuando exista riesgo real de que la persona pueda ser tratada de forma incompatible con el art. 3 en el país de destino. Esta doctrina se extendió más tarde a los casos de expulsión o deportación.

Por último, una muestra bien elocuente de esta tendencia a extender la garantía que ofrece el Convenio a sujetos o situaciones no amparadas inicialmente por el mismo es la evolución que ha seguido en los últimos tiempos la jurisprudencia relativa a la discriminación por razón de orientación o identidad sexual. Se observa, por ejemplo, un giro en la posición del TEDH en dos sentencias relativas a la adopción por parejas homosexuales que dicta en un corto lapso de tiempo. En el asunto Fretté c. Francia (2002) considera que el rechazo de la solicitud de adopción motivado por la orientación sexual de los demandantes está amparado por el margen de apreciación nacional, mientras que en el caso $E$. B. c. Francia (2008), constata la existencia de una diferencia de trato discriminatoria. En último término, ha sido la interpretación del derecho a contraer matrimonio (art. 12 $\mathrm{CEDH}$ ) la que ha evolucionado en los últimos años, con el abandono paulatino de la concepción ortodoxa de una unión entre un hombre y una mujer. Por otra parte, en las dos últimas décadas del pasado siglo, el Tribunal de Estrasburgo había negado en varios pronunciamientos la existencia de una obligación positiva de modificar la inscripción registral de una persona como consecuencia del cambio de sexo, hasta que en el asunto Christine Goodwin contra Reino Unido (2002), cambia de criterio tras tomar nota del progresivo reconocimiento en los distintos ordenamientos de los derechos de los transexuales y declara en una decisión unánime que los Estados ya no pueden seguir invocando su margen de apreciación en la materia, porque ningún interés público puede prevalecer sobre 
el interés de la recurrente en obtener un reconocimiento jurídico de su conversión sexual. Es más, en el caso Van Kück contra Alemania (2003) consideró contraria al Convenio la negativa de las autoridades alemanas a rembolsar los gastos médicos derivados del cambio de sexo del demandante.

\section{VÍCTOR FERRERES COMELLA}

La interpretación dinámica o evolutiva me parece inevitable, dado el contexto normativo e institucional en el que se mueve el TEDH. En primer lugar, el texto básico, el Convenio, consagra derechos humanos a través de cláusulas relativamente abstractas. Tanto la definición de los derechos, como la determinación de los motivos en virtud de los cuales esos derechos pueden ser objeto de restricciones, se recogen en formulaciones normativas abiertas. En consecuencia, el margen interpretativo es amplio. En segundo lugar, la interpretación que el Tribunal desarrolla a partir del Convenio no puede ser fácilmente «corregida» por los Estados. Éstos pueden ampliar la lista de derechos a través de los correspondientes protocolos, pero no pueden modificar en la práctica el Convenio para dar respuesta a la jurisprudencia de Estrasburgo, dada la exigencia de unanimidad. El TEDH sabe que no cuenta con el contrapeso del «poder de reforma» del Convenio, por lo que se ve forzado a adoptar una postura dinámica en materia de interpretación.

Esta postura, por lo demás, no entraña una lesión del principio de seguridad jurídica. En general, el TEDH no realiza giros jurisprudenciales bruscos. Su doctrina evoluciona de forma gradual, preparando el terreno para cambios futuros. Hay que tener en cuenta, además, que las exigencias de certeza jurídica no deben operar del mismo modo en todos los sectores del ordenamiento. Los derechos humanos son en sí mismos un factor de «inestabilidad»: allí donde juegan con fuerza, obligan a la comunidad política a someter a crítica rigurosa las concepciones que han prevalecido tradicionalmente. Los jueces desempeñan un papel crítico cuando examinan alegatos basados en los derechos fundamentales. Por ello, la seguridad jurídica no se puede convertir en una barrera que bloquee la necesaria evolución jurisprudencial en el campo de los derechos.

\section{JAVIER GARCÍA ROCA}

El Convenio, suele afirmar el TEDH, es un instrumento vivo sometido a permanentes transformaciones y debe interpretarse a la luz de las condiciones de vida actuales. Una construcción semejante se visualiza en la bellísima imagen de la Constitución como un árbol vivo (el sol del membrillo de Víctor Erice) del Privy Council británico que trae a colación la STC 198/2012, de 6 de noviembre, sobre el matrimonio homosexual con Ponencia del Magistrado Pablo Pérez Tremps. Los derechos deben interpretarse como instituciones y a la luz de la cultura jurídica que evoluciona constantemente en función de diversos ingredientes como son los cambios culturales y tecnológicos. Una interpretación dinámica y evolutiva es inevitable en la jurisdicción europea. Ilustraré la tesis con algunos ejemplos.

El Caso Matthew contra el Reino Unido, de 18 de febrero de 2001, aplicó el derecho a elecciones libres al Parlamento Europeo, una institución que ni siquiera existía al tiempo 
de crearse el Convenio, pero cómo cerrar las puertas del Convenio a instituciones de la Unión mutuamente aceptadas. Del mismo modo, se aplica al derecho de sufragio en las elecciones municipales que es algo que no prevé expresamente el artículo 3 Protocolo 1 , pero que se adentra en la lógica del bien jurídico protegido: elecciones libres y representación política en cada Estado.

El conocido Caso C. Goodwin contra el Reino Unido, de 11 de julio de 2002, reconoce el derecho al matrimonio de los transexuales y supuso un giro de $180 .^{\circ}$ en la jurisprudencia, que venía dejando hasta entonces la solución de este asunto en la más libre discrecionalidad nacional, más diversos informes auspiciados por la Comisión avalaron en este procedimiento que el género puede comprenderse no sólo desde una perspectiva cromosomática sino también psicológica.

Igualmente, el umbral del sufrimiento tolerable en las sociedades modernas, del padecimiento físico o humillación que pueden ser constitutivos de malos tratos, se ha rebajado considerablemente en los últimos años. Deben verse los Casos Henaf contra Francia, de 27 de noviembre de 2003, y Yankov contra Bulgaria, de 11 de diciembre de 2003, referidos a hechos como son encadenar a la cama a un preso, o raparle el pelo al cero sin necesidad alguna, supuestos a los que hace dos décadas no se les habría dado importancia.

Recordemos también Matbieu-Mobin y Clerfayt contra Bélgica, de 2 de marzo de 1987, que supuso un giro a la hora de interpretar el artículo 3 del Protocolo 1 al identificar un auténtico derecho al sufragio de los ciudadanos y no una simple obligación de los Estados de celebrar elecciones periódicas. Una verdadera transformación de la norma por la jurisprudencia y que he calificado como una mutación del Convenio. Este artículo reflejaba una prudente norma de principios, típica de los años cincuenta y una situación de guerra fría, y no un derecho fundamental, pero devino obsoleto y debía actualizarse. Suponía una contradicción en sustancia con la lógica interna de una declaración de derechos que el Tribunal resolvió asumiendo una perspectiva garantista.

Muy nuevo e importante fue reconocer en Hirst contra el Reino Unido, de 30 de marzo de 2004, que los reclusos pueden tener derechos electorales, acabando con sendos atavismos históricos ligados a la concepción del sufragio como una función de la nación y a un entendimiento penoso de las cárceles y la reclusión como meros encerramientos. Dado que el sufragio tiene una función inclusiva de los ciudadanos en sus comunidades y que las penas privativas de libertad no poseen un carácter infamante ni desapoderan de todos los derechos fundamentales a los presos, no puede anudarse la privación del sufragio activo a toda clase de delitos con independencia de su naturaleza o del tiempo de duración de la pena. La conclusión es irrefutable. Pero el asunto ha levantado ampollas en el Reino Unido y ha dado lugar a una saga de sentencias, fruto de los obstáculos a su cumplimiento.

En este sentido, no ha dejado de objetarse que el Protocolo Adicional no reconoce expresamente un derecho al sufragio. Los valedores de esta tesis originalista olvidan que ni los derechos fundamentales ni cualquier verdadera interpretación constitucional y convencional de los mismos puede contentarse con una interpretación literal. Por eso es frecuente que el TEDH recurra a una interpretación evolutiva y sociológica ${ }^{4}$. No tenemos en Europa defensores, como en Estados Unidos, de una interpretación originalista. Una vez

4 Cfr. R. Canosa: «La interpretación evolutiva del Convenio Europeo de Derechos Humanos» en J. García ROCA y P.A. FERNÁNDEZ ÁNCHEZ, Integración europea a través de derechos fundamentales: de un sistema binario a otro integrado, CEPC, Madrid, 2009, pp. 79-112. 
sentado que las Constituciones no tienen un período de vigencia limitado (el viejo debate entre Jefferson y Madison sobre el papel de la reforma) mantener una interpretación literal y originalista es un absurdo, porque todo Derecho codificado se actualiza mediante reformas o en la jurisprudencia. Pese a ello, han sido recurrentes las protestas en algunos países tras ciertas sentencias polémicas que denuncian tener a judge made Convention y estar sometidos a un activismo judicial.

Me temo que no hay otra alternativa razonable. El legislador democrático no puede agotar en normas la creación de los derechos y menos aún un legislador internacional y convencional, lo impide la naturaleza del objeto. Los derechos fundamentales son un case law y se especifican en torno a concretos supuestos de hecho, mediante interpretaciones motivadas y fundadas en unos parámetros normativos predeterminados, pero sin hechos no hay normas sobre derechos. Las disposiciones convencionales son muy abiertas, aún más que las constitucionales, y sus exégesis son inevitablemente constructivas de normas. El sometimiento a la literalidad de las disposiciones no siempre puede ser intenso.

Estamos, por definición, ante una interpretación evolutiva: nowadays present conditions suele decir el TEDH. A menudo se reprocha en algunos votos particulares que tiendan a valorarse future conditions. Pero toda jurisdicción sobre derechos - y realmente toda jurisprudencia tout court - tiene una pretensión racional, garantista, iluminista y debe mirar hacia el futuro, como nos enseñó Gustavo Zagrebelsky al evidenciar que el juez constitucional es artífice del Derecho. Cuando se corta el patrón de un derecho no puede pensarse en un traje que pronto quede pequeño. Otro tanto acontece con el juzgador convencional. Las constituciones y el Convenio son productos ilustrados fiados a la razón y el progreso.

¿Qué ocurre entonces con la seguridad jurídica? Primero, conviene recordar que el Derecho Constitucional es inevitablemente un diritto morbido, es decir, dúctil, flexible y maleable, según ha argumentado Gustavo Zagrebelsky. Un derecho por principios y no sólo mediante reglas precisas. Ciertas dosis de imprevisibilidad es inevitable en el juicio sobre derechos. Pero esa «impredictibilidad» no es tan intensa, pues se corrige con las técnicas del precedente, la cosa interpretada y el efecto de vinculación. Para un buen conocedor del case-law de Estrasburgo, de sus leading cases y líneas de jurisprudencia, y de sus forma de argumentar la mayor parte de sus pronunciamientos no pueden considerarse que resulten difíciles de adivinar. Un diálogo judicial cada vez más global es también un freno a entendimientos heterodoxos de los derechos por parte de un solo tribunal que se descuelguen de un trabajo en red, soluciones compartidas y plenamente suasorias. Pero hay excepciones y por eso el universo de los derechos es un debate abierto.

\section{LUIS JIMENA QUESADA}

Lo primero que conviene recordar, como premisa, es que el CEDH de 1950 (y los 16 Protocolos que lo han modificado para justamente adecuarse por natural vía normativa a la evolución de la sociedad) recoge cláusulas más o menos genéricas que, en su contenido, son superadas en detalle por la legislación nacional (estatal o autonómica). Por consiguiente, la virtualidad del CEDH deriva de ser un «instrumento vivo» (en expresión del propio TEDH) susceptible de atender a la consecución de la justicia y al respeto de la dignidad humana o, en otras palabras, un instrumento cuyas cláusulas deben verse 
dotadas de efectividad o efecto útil, en principio a través de una actuación de las autoridades internas guiada por la buena fe y, si ello no fuera así, subsidiariamente a través de la supervisión que tiene encomendada en tal sentido el TEDH.

O sea, la adopción del CEDH (y sus Protocolos) como tal y su incorporación al ordenamiento interno quedaría en buena medida desprovista de verdadero alcance si se dejara su cumplimiento al albur exclusivo de las autoridades nacionales, sin el reconocimiento de la jurisdicción del TEDH. Dicho lo cual, la tarea exegética del TEDH es consustancial a su propia existencia como instancia máxima de control del CEDH, viéndose guiada por las reglas al uso de la hermenéutica jurídica, las cuales aparecen previstas en la Convención de Viena sobre el Derecho de los Tratados de 1969 (arts. 31 a 33) y van desde una interpretación más literal o gramatical hasta esa interpretación dinámica o evolutiva que se aleja más del texto convencional.

Con estos parámetros, en el caso de la interpretación del TEDH, es menester subrayar asimismo a modo de premisa que, como sucede con la jurisprudencia constitucional, es claramente fuente del Derecho, lo cual comporta varias consecuencias, a saber: a) se debe tener por superada, en el ámbito de los derechos humanos que nos ocupa, la clásica distinción entre monismo y dualismo al considerar la posición del CEDH y de la jurisprudencia del TEDH; b) ha de quedar relativizada igualmente la tradicional aproximación civilista a la jurisprudencia como mero «complemento» del sistema de fuentes; y c) se ha de atemperar el discernimiento entre interpretación e integración y, por lo mismo, entre fase interpretativa y fase aplicativa de las cláusulas convencionales.

Desde esta perspectiva, la conocida como interpretación dinámica o evolutiva debe concebirse como una técnica hermenéutica más, si bien más distante del texto convencional y, por ende, generadora de una jurisprudencia que básicamente ha propiciado la protección "par ricochet» o indirecta de derechos no explícitamente consagrados en el CEDH por vía de «conexión» con derechos convencionales (salvando así el obstáculo de inadmisibilidad «ratione materiae»). Pues bien, esa jurisprudencia dinámica o evolutiva se ha desarrollado a partir de la idea de «prolongaciones» o «implicaciones» de orden socio-económico (desde la famosa STEDH Airey c. Irlanda de 9 de octubre de 1979) de los derechos (básicamente, cívico-políticos) reconocidos en el CEDH, del derecho conexo o relacional a la igualdad y no discriminación (art. $14 \mathrm{CEDH}$ ) o de otros derechos como la tutela judicial efectiva (art. 6), la propiedad (extendida a las pensiones y prestaciones sociales sobre la base del art. 1 del Protocolo n. ${ }^{\circ}$ ), la protección de la integridad (art. 3 $\mathrm{CEDH}$ ) o el derecho al respeto de la vida familiar y del domicilio (art. 8 CEDH).

Me interesa poner el acento en estos dos últimos preceptos convencionales (y, en especial, en el segundo), a través de los cuales se ha desarrollado una jurisprudencia dinámica y evolutiva nada desdeñable para propiciar el novedoso reconocimiento del derecho a la no expulsión que afecte a personas extranjeras (por efecto de la reagrupación familiar —ya desde la STEDH Berrehab c. Países Bajos de 21 de junio de 1988-) o del derecho al medio ambiente (frente a la contaminación, acústica y de otro tipo —-meridianamente, desde la SSTEDH López Ostra c. España de 9 de diciembre de 1994 o Moreno Gómez c. España de 16 de noviembre de 2004, entre otras-).

Por mi parte, no puedo sino valorar positivamente esa jurisprudencia del TEDH que, tanto en el terreno de la reagrupación familiar de personas extranjeras en supuestos de expulsión como en el campo de la contaminación acústica, ha sido asumida correctamente por los órganos jurisdiccionales ordinarios (por ejemplo, del orden 
contencioso-administrativo); ello ha provocado un efecto de «retroalimentación» normativa (en la legislación sobre extranjería o en las normas ambientales —estatales, autonómicas e incluso ordenanzas municipales-); todo lo cual, finalmente, no ha resultado nocivo para la seguridad jurídica. Si acaso, ha sido curiosamente la jurisprudencia del Tribunal Constitucional la que se ha apartado incomprensiblemente del canon europeo en ambas materias siendo inconsecuente con el mandato interpretativo del art. 10.2 CE (por ejemplo, la ya citada STC 236/2007 con respecto a la vida familiar, FJ 7; y, con relación a las molestias ambientales, la STC 150/2011, de 29 de septiembre — véase el voto particular formulado por Luis Ignacio Ortega Álvarez al que se adhieren Eugeni Gay Montalvo y Elisa Pérez Vera).

Por último, estimo pertinente proceder a un nuevo ejercicio de autocrítica. En particular, en la doctrina ha sido objeto de un balance positivo la jurisprudencia evolutiva o dinámica del TEDH en materia de derechos sociales, poniendo el acento en pronunciamientos como la STEDH Demir y Baykara c. Turquía de 12 de noviembre de 2008. Por el contrario, se ha criticado doctrinalmente el carácter timorato o circunspecto del TEDH a la hora de proteger, sobre la base del CEDH, derechos de las personas con discapacidad (STEDH Botta c. Italia de 24 de febrero de 1998 o Decisión de inadmisibilidad Farcaşc. Rumanía de 30 de septiembre de 2010) o situaciones de pobreza y exclusión social (Decisiones de inadmisibilidad de 23 de abril de 2002 dictada en el caso Larioshina o de 18 de junio de 2009 en el caso Budina, ambas contra Rusia). En mi opinión, semejante crítica doctrinal se revela tanto menos justificada cuanto que el CEDH no fue concebido como un tratado de derechos sociales ni el TEDH como una corte europea de derechos sociales, de manera que se incurre en una suerte de «obsesión convencional» mediante la cual se pide irrazonablemente al TEDH mucho más que una interpretación dinámica o evolutiva. Si no, repárese en la tentación que tenemos de, cada vez que organizamos un seminario o evento académico sobre derechos humanos, forzar la inclusión de una o varias ponencias sobre qué habría dicho la jurisprudencia del TEDH. ¿Y si el TEDH no hubiera dicho nada al respecto, sencillamente porque no fue creado para tal cometido y su «dinámica evolutiva» no le ha empujado a ello?

\section{CARLOS RUIZ MIGUEL}

Para contestar a esta cuestión debemos tener claro qué es «interpretación» del Derecho. Desgraciadamente, la tentación, ya descrita por Montesquieu, de que quien posee poder quiera abusar del mismo también existe entre quienes tienen asignado el poder de interpretar el Derecho. Este abuso de poder, evidentemente, no se presenta como tal, sino que se disfraza de ropajes «atractivos» $\mathrm{u}$ «honorables», llámense jurisprudencia «dinámica», «evolutiva» o «creativa». Más que nunca es necesario recordar que, como ha advertido Otto Pfersmann, la interpretación del Derecho no es la elección y eventual justificación entre opciones «deseables», sino la delimitación de las opciones «admisibles» dentro del texto de la norma. En el mundo del Derecho unos órganos están encargados de «crear» el Derecho y otros de «interpretarlo». La tarea de los tribunales en nuestro sistema jurídico no es la de «crear» Derecho, sino la de «interpretarlo». La interpretación en sentido estricto del Derecho, y de la Constitución, es una garantía de que no se invade la competencia para cambiarlo asignada a determinados órganos con una legitimación 
democrática directa. En consecuencia, respetar los límites de la interpretación no sólo es una cuestión de seguridad jurídica, es también una cuestión de legitimidad política.

\section{ROSARIO TUR AUSINA}

La labor interpretativa de una jurisdicción de naturaleza materialmente constitucional como la del TEDH se inscribe en una relación entre entes que difiere significativamente de la clásica reciprocidad entre Estados y organizaciones internacionales, pues en este último caso, el objetivo es fijar en sus instrumentos normativos concretas obligaciones bilaterales. En efecto, la jurisdicción de Estrasburgo es una apuesta decidida por hacer del Convenio un instrumento vivo y dinámico, que pondera intereses en conflicto, y que intenta ajustarse permanentemente a las condiciones y circunstancias cotidianas de los Estados, alejándose así de las clásicas reglas de interpretación de los Tratados previstas en la propia Convención de Viena de 1969. En un compromiso que implica la construcción paulatina y constante de un acervo constitucional negociado y pactado a la luz, precisamente, de los principios estatales (Gazzardi c. Italia, de 6 de noviembre de 1980, y Soering c. Reino Unido, de 7 de julio de 1989). Se trata, pues, de un pacto constitucional supranacional que no es la simple generación de una verdad europea distinta a las realidades nacionales y que se impone a las mismas, ni tampoco la mera suma aritmética de aquellas, sino un acervo constitucional nuevo construido entre todos los entes a partir de sus propias vivencias constitucionales. Pero en una realidad constitucional compleja, que no es homogénea y que no está habituada ni se halla inmersa en una cultura común del pacto político-constitucional, es fácil detectar el pluralismo, la disparidad, y las diversas vicisitudes de 47 Estados miembros. Ante ello, la interpretación evolutiva o dinámica es una realidad insoslayable, pues no es cuestión de acoger, de forma acumulativa, los cambios cronológicos o temporales, sino de encajarlos y ligarlos además a las experiencias constitucionales propias de cada Estado.

El Tribunal se inspira, precisamente, en las técnicas interpretativas propias de las tradiciones constitucionales de los Estados miembros y se muestra consciente, tanto de que los valores y principios constitucionales están en permanente evolución, como también de que esta organización debe ser efectiva y no limitarse a proteger derechos meramente teóricos ni platónicos. El principio pro persona, que le obliga a interpretar extensivamente los derechos y restrictivamente sus límites, es asimismo un importante incentivo al uso de dicha interpretación dinámica. Ello explica que se aleje del valor que la Convención de Viena da a los trabajos preparatorios y a los elementos que rodearon la elaboración del Tratado (García Roca, «El diálogo entre el Tribunal Europeo de Derechos Humanos y los Tribunales Constitucionales en la construcción de un orden público europeo», TRC, 2012).

Pero el TEDH no olvida que debe un respeto y consideración a las voluntades estatales, por lo que la constatación de estándares nacionales más o menos consensuados o coincidentes es un elemento importante para el uso extensivo de dicha interpretación evolutiva (Fretté c. Francia, de 26 de febrero de 2002). Por ello no impone su criterio en abstracto o desde el estricto parámetro aislado del Consejo de Europa, como si esta organización se sobrepusiera sobre las Altas Partes contratantes. Y tampoco utiliza formas autoritarias, jerárquicas ni totalitarias, aunque a veces las resoluciones sean así transmitidas por los 
propios medios de comunicación y por determinados operadores jurídicos y políticos. De hecho, ello iría en contra de la propia naturaleza de esta organización, que pretende la construcción de estándares en armonía con los mismos Estados, con una pedagogía que hemos reclamado en diversas ocasiones para nuestra jurisdicción constitucional, pero que aquí se multiplica porque juega o interactúa con nada menos que 47 sistemas constitucionales. Y ello aunque efectivamente tenga una posición de cierto predominio o liderazgo que parece que continuamente intenta ganar a los Estados - lo que conlleva también importantes dosis de valentía a las que, con elegancia y prudencia, no debería renunciar en determinados momentos-. Un predominio o cierta posición de ventaja que compensa, precisamente, con diversas técnicas argumentales (margen de apreciación nacional, proporcionalidad...) y ciertas previsiones institucionales (la presencia del juez nacional en las demandas contra su propio Estado, el excepcional doble recurso...). No hay otro modo de construir una verdad europea plural pero comprometida, sino a partir de las propias evoluciones estatales, para hacerla suya y extenderlas al resto en un permanente diálogo. Lo contrario sería obviar la propia naturaleza del Consejo de Europa.

Es cierto que se le achaca a la interpretación evolutiva la indefinición y la inseguridad, hasta convertir a la justicia en un operador que mueve el derecho a su antojo. Sin embargo, si bien es cierto que estos riesgos existen, como existe en la institución parlamentaria y en los gobiernos el peligro de la arbitrariedad política desmedida, no lo es menos que para ello deben darse importantes contrapesos que provienen, en efecto, de las diversas técnicas argumentativas que usa la jurisdicción de Estrasburgo. A ello se añade que la naturaleza de justicia constitucional del Tribunal Europeo le convierten en un intérprete singularmente autorizado para actualizar y dinamizar el Convenio en conexión con las tradiciones constitucionales, al modo en que los Tribunales Constitucionales son, en los ordenamientos internos, las instituciones especialmente idóneas para adaptar el texto constitucional a la realidad, para que sólo en casos insalvables se acuda a la reforma de las Constituciones.

Por otro lado, respecto a la posible vulneración de la seguridad a través del uso de la interpretación evolutiva, conviene desechar la idea de aquella es un principio, un valor o incluso un derecho fundamental. Nos encontramos en realidad con un bien constitucional/convencionalmente protegido, del que se derivan pretensiones para la ciudadanía en orden a la actuación de los poderes públicos, que no puede ser arbitraria sino previsible, y que ha de lograr con ello como resultado un equilibrio y una armoniosa relación entre el derecho, la justicia y la libertad, de tal modo que si el derecho no se impone no será posible pensar en seguridad, como tampoco lo será pensar en la libertad ni en la igualdad (Punset, «Seguridad, Libertad, Constitución», Cuadernos de Alzate, 2004). Por ello, seguridad jurídica y libertad, como a veces se pretende, no son términos antagónicos ni dialécticos, no teniendo sentido aquellos razonamientos que ponderan uno con el otro, pues en realidad se sitúan en planos ontológicos distintos.

La falta de seguridad no se produce, por lo tanto, por el mero uso de la interpretación evolutiva, sino por las débiles condiciones en que ésta tenga lugar, pues la inseguridad es en realidad la ausencia de Estado, entendido ello como una práctica que prescinda de las normas y de la argumentación jurídica, de los límites, y de la libertad y la igualdad misma. Por ello es este sentido de Estado de la jurisdicción de Estrasburgo, el presupuesto en realidad de un bien constitucional/convencional como es la seguridad, en cuanto es tarea del Tribunal contribuir a construir y hacer eficaz el ordenamiento convencional en diálogo constante con las Constituciones. 
Es más, la idea de seguridad — mal entendida entonces- no debería nunca convertirse en una excusa para evitar interpretaciones evolutivas. Ello ocurrirá, en efecto, cuando quiebren los elementos democráticos de los Estados o falte una normatividad constitucional plena, pues en dichos casos la seguridad se convierte dentro de los Estados en un orden ideal, lo disidente representa un peligro para el orden y para las personas mismas, y en consecuencia el Tribunal de Estrasburgo podría replegarse impidiendo el avance deseado. Esto corrobora, precisamente, que el Consejo de Europa imponga como condición el carácter verdaderamente democrático de los Estados, lo que favorece y abre el camino a las interpretaciones evolutivas.

4. ¿Cómo valora el que la jurisprudencia del TEDH respete el llamado margen de apreciación nacional? ¿Y su compatibilidad con otros valores básicos del orden constitucional, como el de seguridad jurídica?

\section{ENOCH ALBERTÍ ROVIRA}

El llamado margen de apreciación nacional, que va más allá de la clásica deferencia o self restraint que deben mantener los altos tribunales respecto de los poderes democráticos cuyos actos enjuician, parece inevitable en la actuación del TEDH, tanto por la gran cantidad y la heterogeneidad de los Estados que forman parte del Convenio de Roma, con tradiciones jurídicas, políticas y culturales muy diversas, como por el carácter internacional de este instrumento de protección de los derechos. El margen de apreciación nacional nació como doctrina jurisprudencial del TEDH (aunque no es exclusiva del Tribunal de Luxemburgo, pues se ha desarrollado también en el ámbito de otros tribunales internacionales, como el TJI, o supranacionales, como el TJUE), pero ha encontrado eco en el propio CEDH, cuyo Protocolo n. ${ }^{\circ} 15$, de 2013 , firmado pero aún no ratificado por España, añade un párrafo al Preámbulo del Convenio, en el que vincula claramente el margen de apreciación nacional con el principio de subsidiariedad y, asimismo, lo sujeta al control del propio Tribunal. Creo que estas dos ideas son decisivas para enmarcar esta doctrina y, por tanto, fijar algún criterio para su aplicación, pues la inseguridad o la ausencia de límites claros constituye el gran problema que unánimemente se señala al respecto.

Por una parte, en efecto, la subsidiariedad remite a la idea esencial de que la protección de los derechos corresponde esencialmente a los Estados, y que el TEDH no puede sustituirlos. Son los Estados quienes deben asegurar primariamente —y principalmente puede decirse también - el respeto de los derechos, y son ellos también, en consecuencia, quienes deben apreciar las circunstancias que permiten, en aplicación del propio Convenio, establecer límites y excepciones. Por ello hay una larga tradición de aplicación de la doctrina del margen de apreciación nacional en relación a casos de limitación de derechos o de establecimiento de situaciones de excepción (ya desde SSTEDH Lawless v. Irlanda, 1961; Handyside v. RU, 1976; Irlanda v. RU, 1978, entre otras), en los que, en general, se reconoce que las autoridades estatales se encuentran en una mejor posición que un órgano judicial internacional para valorar las circunstancias, previstas genéricamente en el Convenio, que permiten adoptar medidas restrictivas de los derechos. Pero al mismo tiempo, la adopción de estas medidas se sitúa bajo el control del Tribunal, según los 
principios de necesidad y proporcionalidad, llegando, si cabe, a negar, por aplicación de estos principios, que las mismas quepan dentro del margen de apreciación de las autoridades estatales (así, SSTEDH Open Door v. Irlanda, 1992; Hirst-2 v. RU, 2005, entre muchas otras).

Junto a esta línea de aplicación de la doctrina del margen de apreciación nacional, que entronca fácilmente con la de la apreciación política y sus límites, propia también de otros tribunales, especialmente los constitucionales, con la que en gran medida comparte problemática, creo el margen de apreciación nacional expresa también, en otro tipo de casos, la enorme diversidad e incluso heterogeneidad jurídica, política y cultural de los Estados que forman parte del Consejo de Europa y la necesidad ineludible de respetarla desde este instrumento de protección de los derechos de naturaleza internacional. Cuando, por ejemplo, la Gran Sala del TEDH decide finalmente, aplicando la doctrina del margen de apreciación nacional, que la presencia de crucifijos en las aulas de las escuelas públicas (Lautsi v. Italia, 2011, Gran Sala) no supone una vulneración del art. 2 del Protocolo 1 (derecho a la instrucción conforme a las convicciones religiosas y filosóficas de los padres) en realidad está delimitando el contenido convencional del derecho a la instrucción según las convicciones religiosas que garantiza el Convenio y, por tanto, está fijando un determinado estándar mínimo de este derecho, que no alcanza a prohibir este símbolo religioso en las aulas públicas en Italia. El margen de apreciación nacional se ha usado aquí para definir o delimitar de algún modo el contenido del derecho, estableciendo un mínimo común a un determinado nivel. Y el motivo no es otro que el acomodo del derecho reconocido en el CEDH a la diversidad de culturas y tradiciones. Este símbolo, en Italia, dice el TEDH, no genera presión ni discriminación entre los estudiantes y no constituye una forma de adoctrinamiento (en cuyo caso sí vulneraría el Convenio) y, por tanto, su mantenimiento - $\mathrm{O}$ no- recae bajo el margen de apreciación nacional de Italia. El margen de apreciación se ha utilizado para establecer un determinado contenido y nivel de protección del derecho reconocido en el Convenio. En la determinación de este contenido convencional y de su correspondiente nivel de protección europeo ha pesado sin duda el hecho de que intervinieron otros 10 Estados junto a Italia, sosteniendo su posición, demostrando con ello que no había un consenso generalizado en torno a la cuestión, de modo que se pudiera definir el contenido del derecho a la instrucción según las propias convicciones filosóficas en unos términos que excluyeran la presencia de crucifijos (al menos, y no cualquier otro símbolo religioso) en las escuelas públicas. Ahí es donde, a partir de un notable self restraint por parte del Tribunal, adquiere un sentido nuevo la doctrina del margen de apreciación nacional, que va más allá de reconocer un espacio de discrecionalidad para valorar los motivos que justifican una determinada restricción de los derechos, para pasar a convertirse en elemento que contribuye a definir el contenido del derecho y su estándar de protección europeo.

Hay que poner de relieve, sin embargo, como han hecho todos los autores que se han ocupado de la cuestión, que el uso de esta doctrina genera problemas de inseguridad, pues no están nada claros los criterios utilizados para su aplicación. Se ha destacado que confluyen muchos factores y que en su aplicación el TEDH utiliza muchos ingredientes, lo cual sin duda es cierto, y ello, cuando se emplean sin mucha claridad y de forma no sistemática ni articulada, genera un déficit de predictibilidad que es altamente perturbador y criticable en cualquier actuación jurisdiccional. Aun así, probablemente, el mantenimiento de la doctrina del margen de apreciación nacional, con los problemas que 
conlleva (y sin que ello signifique que el Tribunal no pueda perfilar mejor estos criterios y articularlos metodológicamente, cosa que sería altamente deseable) es el precio a pagar por mantener vivo un sistema de protección de derechos de naturaleza internacional sobre un territorio tan extenso y diverso como el europeo. No es nueva la tensión que aquí se manifiesta entre extensión e intensidad: en este caso, a mayor extensión de la protección de los derechos (tanto del ámbito de los derechos protegidos como del ámbito territorial de aplicación de la garantía), menor intensidad en su protección, o, al menos, intensidad selectiva (en relación con algunos derechos en especial, vinculados al núcleo duro de los mismos, tanto desde un punto de vista individual como colectivo, que pueden alcanzar un alto nivel de protección, mientras que en los demás este nivel se relaja).

\section{JUAN MARÍA BILBAO UBILLOS}

Como es sabido, aunque es al Tribunal al que corresponde pronunciarse en última instancia sobre la compatibilidad de la restricción denunciada con los derechos garantizados por el Convenio, los Estados gozan de un notable margen de apreciación (no ilimitado). Esta doctrina jurisprudencial, que limita el alcance de sus facultades de revisión y enjuiciamiento, ha sido finalmente codificada en el art. 1 del Protocolo $n{ }^{\circ} 15$-aprobado en 2013, pero que aún no está en vigor porque cuatro Estados (España, entre ellos) no lo han ratificado - que prevé la inclusión en el preámbulo del Convenio de una mención expresa al «margen de apreciación nacional». Cuando ejerce este control, la misión del Tribunal no es sustituir o suplantar a los órganos internos competentes, que son los que están en mejores condiciones para analizar sobre el terreno todas las variables relevantes y evaluar los posibles riesgos, sino verificar bajo el ángulo del Convenio las decisiones que aquellos han adoptado. Se limita, por tanto, a comprobar si las autoridades del Estado demandado se han basado en una apreciación aceptable de los hechos y si los motivos invocados para justificar la injerencia son pertinentes y suficientes.

La apelación al margen de apreciación de los Estados es una válvula de escape que está plenamente justificada en el marco de una organización que aglutina a 47 Estados con tradiciones jurídicas y estándares de protección de los derechos humanos muy dispares. En la medida en que el control ejercido por el TEDH es, por definición, subsidiario, esa heterogeneidad le obliga a autocontenerse y optar por un control de mínimos. El Convenio no marca el techo de protección, sino el suelo, el común denominador: los ordenamientos nacionales pueden ir más allá y establecer un nivel de protección superior o reforzado. Por esa razón, el TEDH tiene que actuar con prudencia, asegurándose de que existe ya un consenso europeo suficiente a la hora de reconocer un nuevo contenido de determinado derecho. No puede asumir siempre el papel de un tribunal pionero que se coloca en la vanguardia, que va abriendo nuevos caminos. Tiene que cerciorarse antes de que pisa suelo firme. Con esa actitud de deferencia hacia el modo en que interpretan los tribunales nacionales los derechos del Convenio se evitan conflictos y polémicas que podrían afectar negativamente a la auctoritas del Tribunal.

El Tribunal ya perfiló esta doctrina en el famoso caso Handyside c. Reino Unido (1976). En un ámbito en el que no había una posición uniforme entre los Estados parte, como era la protección de la moral, consideró que las autoridades nacionales gozaban de un cierto margen de apreciación al estar en una mejor posición para decidir. También se invocó 
tempranamente para limitar la intensidad de la revisión en situaciones de emergencia o suspensión de garantías (art. 15 CEDH). Pero la aplicación de esta doctrina por el Tribunal es bastante errática e imprecisa, no se atiene a unas pautas claramente reconocibles. La casuística no deja entrever cuáles son los criterios que resultan determinantes a la hora de resolver el dilema entre convalidar la actuación del Estado demandado, con el argumento de que es necesario respetar su margen de apreciación, o revisar sus decisiones como supremo intérprete del Convenio. Se echa en falta una construcción dogmática más depurada de esta categoría, de esta regla de autocontención o «no decisión».

Uno tiene la impresión de que el Tribunal utiliza esta fórmula como excusa cuando quiere eludir una cuestión comprometida. Si uno analiza la jurisprudencia del TEDH advierte enseguida, por ejemplo, que el control que ejerce el Tribunal suele ser más deferente si la restricción se inscribe en el contexto de la lucha contra el terrorismo. Se observa en este terreno una tendencia a respetar el margen de apreciación nacional, aunque no ha dudado en condenar los excesos.

Esa deferencia parece una opción sensata cuando se trata de asuntos delicados o sensibles en los que no existe consenso. A nadie se le oculta, por ejemplo, que en Europa existen diversos modelos de relaciones Iglesia-Estado (desde el confesional hasta el radicalmente laico). Y esa pluralidad es sin duda un dato relevante que hay que considerar. Pero ese respeto por la peculiar idiosincrasia nacional no siempre justifica de modo convincente la renuncia del Tribunal a establecer un estándar mínimo común. La Sentencia de la Gran Sala en el asunto Lautsi c. Italia (2011) es emblemática en ese sentido, porque invocó ese margen de discrecionalidad para no condenar a Italia por la presencia de crucifijos en las aulas de los colegios públicos.

Obviamente, la extensión de ese margen de apreciación varía en función del derecho involucrado. En el caso de la prohibición de la tortura y los malos tratos (art. 3 CEDH), se trata de una prohibición taxativa, absoluta, que no admite excepciones, que no puede ser derogada en ninguna circunstancia (art. $15 \mathrm{CEDH}$ : ni siquiera cuando se declara un estado de guerra, emergencia o excepción). En línea con la establecida en los Tratados y convenios internacionales sobre la materia. El Tribunal ha llegado a sostener que «incluso en las circunstancias más difíciles, como la lucha contra el crimen organizado y el terrorismo, el Convenio prohíbe en términos absolutos la tortura y las penas o tratos inhumanos o degradantes» (Chahal contra Reino Unido, 1996).

Tampoco disponen los Estados de ese margen cuando está en juego el derecho a la protección jurídica de la vida, un derecho que admite muy pocas modulaciones. En principio, al menos, porque sí se ha acudido a este expediente en los asuntos relacionados con el suicidio asistido y la aspiración a una muerte digna o el aborto, cuestiones especialmente controvertidas. La criminalización del aborto se aborda directamente en el caso $A$, B y C c. Irlanda (2010). El Tribunal tenía la oportunidad de fijar el estándar europeo de protección de la vida humana en formación y, simétricamente, el derecho de la mujer embarazada a abortar. Pudo haber declarado contraria al Convenio la prohibición del aborto en Irlanda, por excesivamente rigurosa, es decir, por insuficiente protección de otros bienes como la salud de la mujer embarazada (no se admite el aborto en el supuesto de grave riesgo para la salud física o psíquica de la mujer), pero no lo hizo. A su juicio, el aborto no es un derecho de las mujeres embarazadas que deba prevalecer sobre la protección que se dispensa al feto (ni siquiera durante las primeras semanas de gestación). En el caso de las demandantes A y B, el Tribunal examina si la prohibición del aborto por 
razones de salud o bienestar vulnera el derecho al respeto de la vida privada de las demandantes y llega a la conclusión de que la limitación persigue una finalidad legítima (la protección de "profundos valores morales» de la sociedad irlandesa en relación con la vida humana) y es necesaria en una sociedad democrática. La sentencia admite que en casi todos los países se regula el aborto de forma menos severa y se considera lícito el aborto por razones de salud o bienestar de la mujer, pero no existe realmente ese consenso europeo sobre cuándo comienza la vida humana, y, en consecuencia, el margen de apreciación estatal es máximo. Una afirmación discutible, porque sí parece que hay un amplio consenso en este aspecto.

En principio, el deber constitucional de proteger la vida humana obliga al Estado a sancionar penalmente la inducción y la cooperación al suicidio en cualquiera de sus formas, pero en las últimas décadas se ha ido abriendo paso la idea de que en ciertos supuestos la penalización del suicidio asistido (cuando se presta auxilio a quien desea su propia muerte, pero no puede cumplir ese deseo sin la ayuda de terceros) no es la respuesta más adecuada. En la Sentencia dictada en el caso Pretty c. Reino Unido (2002), la demandante era una enferma terminal de ELA que quería elegir el momento y la forma de morir, con la ayuda de su marido. El Tribunal consideró que el artículo 2 del Convenio no confiere el derecho a morir. Sin zanjar la cuestión de modo definitivo (es prudente), viene a decir que hoy por hoy, el derecho a la vida no incluye la facultad de disponer de ella. Pero en la Sentencia de la Gran Sala en el asunto Lambert y otros c. Francia (2015), en respuesta a la demanda presentada por la familia de Vincent Lambert, un tetrapléjico a quien los médicos que le atendían habían suspendido el suministro de alimentación e hidratación artificial, una decisión avalada por el Conseil d'État, el Tribunal concluyó que la suspensión del tratamiento para no prolongar artificialmente la vida no entrañaba un incumplimiento de la obligación positiva de proteger la vida que incumbe al Estado. Tras constatar la falta de consenso entre los Estados miembros del Consejo de Europa en todo lo que concierne al final de la vida, la Gran Sala considera que se les ha de otorgar a éstos un cierto margen de apreciación. Dicho de otro modo, la competencia para verificar si la decisión de suspender el tratamiento era compatible o no con la legislación nacional y el Convenio recaía principalmente en las autoridades nacionales.

La cuestión de la eutanasia o el derecho a una muerte digna se ha planteado también desde la perspectiva del art. 8 del Convenio. En el caso Haas c. Suiza (2011), se discutió si en virtud de este derecho el Estado tenía el deber de asegurar que una persona enferma que deseara suicidarse pudiera conseguir una sustancia letal sin prescripción médica, con el objetivo de que pudiera suicidarse sin dolor y sin riesgo de fracaso. El demandante alegaba que su derecho a poner fin a sus días de manera segura y digna no fue respetado en Suiza debido a los requisitos exigidos para obtener la sustancia en cuestión (una receta médica, emitida sobre la base de un examen pericial psiquiátrico), que él no cumplía. El Tribunal no apreció ninguna violación del artículo 8. Y para justificar la existencia de un amplio margen de apreciación nacional en estos casos, apeló una vez más a la falta de consenso entre los Estados miembros en este punto, porque a pesar de que el suicidio asistido había sido despenalizado (al menos parcialmente) en algunos Estados, la mayoría de ellos parecían dar más peso a la protección del derecho a vida del individuo que a su derecho a poner fin a la misma. Sin embargo, en el asunto Gross c. Suiza (2013), un caso análogo al de Haas (una persona mayor que deseaba poder fin a su vida, aunque en este caso no sufría ninguna patología clínica concreta y no había podido obtener una dosis letal del 
medicamento necesario para suicidarse), el Tribunal parece apartarse de esos precedentes, porque la mayoría de la Sala consideró que las autoridades suizas violaron el artículo 8 al negarle a la demandante su derecho a decidir con qué medios y en qué momento de su vida podría cometer el suicidio.

\section{VÍCTOR FERRERES COMELLA}

La doctrina del margen de apreciación nacional ha permitido al TEDH proyectar diversos grados de intensidad de escrutinio a las decisiones adoptadas por los Estados. El Tribunal establece diversos niveles de deferencia judicial en favor de las autoridades nacionales, en función de una serie de consideraciones. Hay que recordar que también los tribunales constitucionales modulan la intensidad del control cuando tienen que enjuiciar las normas y actos del poder público. Ahora bien, mientras que una de las claves para entender la deferencia judicial en el plano doméstico tiene que ver con la necesidad de mantener un espacio para la libre configuración del legislador democrático, el TEDH centra su atención en la existencia o no de suficiente consenso en torno a determinada cuestión en el ámbito del Consejo de Europa. Ciertamente, el TEDH no ha sido muy riguroso a la hora de aplicar esta doctrina. Es posible que la seguridad jurídica resulte, por ello, afectada. Pero me parece correcto que el control de Estrasburgo no tenga la misma intensidad en todos los casos, y se otorgue relevancia al grado de convergencia que aflora en el seno del Consejo de Europa en torno a determinada cuestión, o a la existencia de una tendencia que apunta claramente en una dirección de mayor protección de los derechos.

\section{JAVIER GARCÍA ROCA}

Una consecuencia de la naturaleza limitada de una protección internacional y de la subsidiariedad es la llamada doctrina del margen de apreciación nacional. Siguiendo esta herramienta, el Tribunal Europeo se autolimita y, en ciertas ocasiones, mantiene una diplomática deferencia con las decisiones de las autoridades nacionales respecto de algunos derechos, pero no en todos y desde luego no en los absolutos. Es así especialmente en conflictos culturales muy sensibles para las opiniones públicas de algunas sociedades nacionales v.gr. el crucifijo en las escuelas, el velo islámico en las cabezas, la ordenación de la llamada prostitución no forzada o del suicidio asistido o de la gestación subrogada y un largo etcétera de asuntos controvertidos donde no existe un consenso europeo.

Como ya he razonado en una monografía ${ }^{5}$, creo que la verdadera justificación de esta imprecisa herramienta está en el intenso pluralismo cultural de base territorial de los países europeos: de Lisboa a Vladivostok, de Noruega a las Islas Canarias. Un pluralismo que aconseja prudencia en algunas decisiones para no generar más problemas, siguiendo un

5 Cfr. J. García Roca: El margen de apreciación nacional en la interpretación del Convenio Europeo de Derechos Humanos: soberanía e integración, Civitas, Madrid, 2010; y antes, en esta misma revista, «La muy discrecional doctrina del margen de apreciación nacional según el Tribunal Europeo de Derechos Humanos: soberanía e integración» en Teoría y Realidad Constitucional, n. ${ }^{\circ}$ 20, 2007. 
despotismo ilustrado en Estrasburgo, que los que pueden realmente resolverse, en vez de dejar la solución de asuntos delicados en manos de cada uno de los legisladores democráticos. Esta especial sensibilidad internacional reclama la autocontención del juzgador europeo ante algunos conflictos culturales donde no existe todavía un denominador común: un common background o consenso normativo europeo. Las sentencias europeas aportan cada vez más frecuentemente un serio estudio de Derecho comparado, revisándose las diversas regulaciones nacionales en Europa por parte del TEDH, que es el tribunal comparatista por excelencia en palabras de Giuseppe Vergottini. La introducción de la técnica comparada me parece imprescindible para estos fines y está ya muy consolidada.

Sin embargo, el margen es una imprecisa herramienta jurisprudencial que posee una acusada dependencia del contexto, caso a caso, lo que es, al tiempo, su principal virtud y mayor defecto. Una vuelta a la justicia del pretor que genera inseguridad jurídica, pues no hay un edicto que nos de pistas de la hoja de ruta. En mi monografía, sugería desagregar los ingredientes del margen y usar otras técnicas como puede ser no revisar normalmente - salvo manifiestas arbitrariedades - la prueba de los hechos, que deben ser practicada por los jueces nacionales ni la interpretación del Derecho interno. Pero con todo, el margen no es sino una mezcla de justicia y diplomacia en cada caso.

No en balde, rara vez el método comparado hace aflorar una única regulación en los Estados miembros en vez de revelar muy diversas soluciones. No es extraño pues que su uso resulte impredecible y haya sido muy discutido por bastantes expertos. Por más que creo que este criterio no pueda ser abandonado en el estadio actual de la integración europea. Es realista pensar que simplemente debe limitarse su uso y formalizarse el juicio todo lo posible.

Las cuestiones religiosas o morales suelen constituir un buen territorio para respetar un margen de discrecionalidad nacional según ilustra el Caso Leyla Shalin contra Turquía, de 10 de noviembre de 2005, sobre la controvertida prohibición del velo en la Universidad de Estambul. Igualmente el asunto S.A.S. c. Francia, de 1 de julio de 2014, donde una Gran Sala se pronuncia sobre la adecuación al Convenio de la Ley aprobada por el Parlamento francés a fin de prohibir la utilización de prendas que disimulen el rostro en cualquier espacio público. También los no menos polémicos Casos Lautsi I y II, de 3 de noviembre de 2009 y 18 de marzo de 2011, respecto del empleo del crucifijo en las escuelas públicas en Italia, donde una Gran Sala cambió radicalmente de criterio respecto de la Sala tras una fuerte campaña de presión internacional de países y asociaciones religiosas. Reviste especial interés el Asunto Lambert y otros contra Francia, de 6 de junio de 2015 , donde se estimó que no hay un consenso entre los Estados miembros en relación con la retirada de tratamientos o soporte vital de personas que se encuentran en fase terminal o en estado vegetativo, por lo que se reconoció que el margen de apreciación nacional debe ser muy amplio. También Paradiso y Campanelli contra Italia, de 24 de enero de 2017 , donde se admite que la falta de consenso europeo sobre la gestación subrogada propicia un amplio margen de apreciación nacional. Así p.ej. los Grupos parlamentarios españoles no se muestran en nuestros días de acuerdo sobre cómo regular este tema al adelantarse la presentación de una proposición de ley de un Grupo parlamentario.

Ahora bien, si dejamos a un lado estos casos en asuntos muy polémicos y sensibles, he tenido la impresión durante muchos años de que el TEDH acudía menos a la técnica del margen como verdadera ratio decidendi. Es verdad que, muy a menudo, el Tribunal dice en su fundamentación reconocer un amplio margen de apreciación nacional, y esto 
induce a confusión, pero es a veces un mero obiter dicta, pues tiende luego a hacer justamente lo contrario y resolver el asunto desde sus propios criterios no siempre coincidentes con los nacionales. Pese a que esta forma de proceder no esté exenta de contradicciones y pueda resultar paradójica, responde a una aproximación pragmática y algo elusiva muy típica del Tribunal Europeo, poco amigo de soluciones abstractas.

Un dilema clásico — sin fácil respuesta — es cuándo conviene integrar, armonizar u homogeneizar los derechos y sus garantías y cuándo debe respetarse un pluralismo y la soberanía nacional. En otras palabras, cuándo conviene respetar dicho margen de apreciación o, por el contrario, debe acometerse lo que he llamado una integración funcional entre los europeos siguiendo el concepto constitucional de integración de Rudolf Smend: la lenta construcción de una cultura común. El Caso Tyrer contra el Reino Unido, de 25 de abril de 1978, ilustra bien cómo la tradicional práctica de los castigos corporales en las escuelas, a ojos de la mayoría de los británicos entonces plenamente aceptable, no podía ser tolerada por el resto de las sociedades europeas donde repugnaba por violenta, $y$, en consecuencia, se impuso la unificación de un estándar: vetar los castigos corporales.

De un lado, el CEDH no es una declaración federal de derechos que conviva con las declaraciones de los Estados federados. Los europeos tenemos un sistema de garantías multiniveles, y el Convenio no fue diseñado como una codificación federal. Pero la cuestión es más compleja. Pues, por otro lado, el objetivo del sistema, según el preámbulo del CEDH y el Estatuto del Consejo de Europa, es realizar «una unión más estrecha» de los europeos, es decir, alcanzar una concepción de los derechos sustancialmente igual o equivalente. Esta contradicción no tiene una fácil síntesis; es ilógico creer que toda tesis y antítesis concluye en una síntesis.

Desde esta segunda perspectiva, el Convenio es un límite estructural y externo a la soberanía de los Estados. Autores como Neil Walker han hablado en el contexto de la Unión de una «soberanía en transición». También en el Consejo de Europa. Ya no pueden verse como problemas internos las matanzas en el Kurdistan en Turquía, la expulsión masiva de georgianos en Rusia, o no investigar suficientemente los malos tratos a los terroristas de ETA, cuestión por la que nos han condenado varias veces. Esta complementariedad entre controles internos y externos me parece un gran avance. Desde antaño, la filosofía se ha preguntado si el observador imparcial ve mejor el conflicto desde dentro o desde fuera, pues bien el sistema multinivel de garantías que tenemos nos permite aunar los mejores frutos de ambos enjuiciamientos: uno cercano a los hechos y otro más distante e independiente. No hace falta elegir...

Tras las conferencias de Interlaken (2010), Izmir (2011) y Brighton (2012), el Protocolo 15 de 2013 propuso introducir una mención a la subsidiariedad y al margen de apreciación nacional en el preámbulo del Convenio, reconociendo que la primera responsabilidad en la garantía de los derechos corresponde a los Estados. La última afirmación es muy cierta. Pero el Protocolo no índica ni qué es el margen ni cuándo debe aplicarse ni en qué círculo de derechos ni con qué criterios ni cómo debe limitarse el supuesto activismo del Tribunal Europeo. De producirse su entrada en vigor, — tienen que ratificarlo todos los Estados y aún no lo han hecho-, no creo contribuya a clarificar mucho el estado de la cuestión. Estimo que la propuesta es más un símbolo o una concesión al nacionalismo de algunos Estados, y un recordatorio a un Tribunal internacional de sus limitaciones, que una verdadera aportación al debate jurídico y a la mejora del funcionamiento de la jurisdicción. También la Declaración de Copenhague de 13 de abril de 
2018 ha reclamado la ratificación del Protocolo 15, y ha insistido en la subsidiariedad, así como advertido de la responsabilidad de los Estados en una efectiva implementación del Convenio como primeros garantes del mismo, proponiendo una serie de medidas, entre ellas, que se involucren en la ejecución de las sentencias.

La verdad es que, desde Brighton, podría está apareciendo —así lo señalan diversos profesores de otros países - una nueva aproximación más respetuosa del margen de apreciación y un nuevo método de resolución. Algunos autores hablan del criterio de la razonabilidad del procedimiento (procedural rationality review) y afirman que podría estar incorporándose a la jurisprudencia. Pero no advierto todavía que así sea de forma expresa, clara y continuada en un buen número de sentencias.

Siguiendo este nuevo parámetro, bastaría con que el TEDH evalué el proceso con el que se ha tomado una determinada decisión polémica a nivel nacional, para cerciorarse de que se han ponderado razonablemente por las autoridades nacionales los intereses contrapuestos en juego. En otras palabras, el Estado demandado debe aportar suficientes indicaciones sobre las razones en que su decisión se funda y, si el procedimiento decisorio ha sido razonable y con cautelas, la supervisión del Tribunal de Estrasburgo podría detenerse. El juicio europeo revierte entonces en una revisión procedimental sobre la calidad de la decisión, respetando las identidades y tradiciones constitucionales nacionales. La construcción es sensata.

Pero sinceramente creo que es pronto todavía para saber, primero, si este criterio se va a asumir en la realidad de forma estructural por el TEDH o se trata de una mera propuesta doctrinal y de una lectura de la jurisprudencia no sé si sesgada, y, segundo, si la pauta de la racionalidad del procedimiento de toma de decisiones va a cambiar algo el estado de las cosas o, por el contrario, tiene bastante de ampulosa retórica anglosajona con base más filosófica que de construcción jurídica. Suena mucho a las conocidas ideas de John Ely sobre una aproximación procedimental a la teoría de la judicial review antes que sustantiva. Pero siempre he pensado — con realismo- que los jueces constitucionales y convencionales inevitablemente infieren juicios morales en sus ponderaciones y les pagan por eso. Probablemente, este estándar formal, bastante lógico, puede usarse al revisar el margen de apreciación nacional, pero no creo permita desechar otros ingredientes del mismo ni monopolizar el juicio de supervisión europeo. Lamento no tener todavía ideas más claras al respecto.

\section{LUIS JIMENA QUESADA}

El llamado «margen de apreciación nacional» constituye una línea de acción del TEDH desde sus inicios, como lógica expresión de la subsidiariedad con la que fue concebido con respecto a los órganos jurisdiccionales nacionales y al papel primordial de éstos en la defensa de los derechos fundamentales en el ámbito interno. Cabalmente, el propósito del CEDH no consistía en armonizar minuciosamente los órdenes constitucionales de las Partes Contratantes, sino en compartir unos estándares básicos que propiciaran el asentamiento de los pilares básicos del Consejo de Europa (el Estado de Derecho, la Democracia y los Derechos Humanos). Obviamente, en cuestiones controvertidas que no son objeto de consenso europeo (o de una «tradición constitucional común», según la expresión utilizada en el ámbito más reducido de la UE -art. 6.3 TUE) y, en consecuencia, es difícil forjar una 
«opinio iuris communis», el TEDH ha sido objeto de críticas desde lados opuestos, ora como artífice de un ataque al orden constitucional de un país (por ejemplo, en materia de aborto: véase STEDH Open Door y Dublin Well Woman c. Irlanda de 29 de octubre de 1992), ora como condescendiente con dicho orden (verbigracia, en relación con el crucifijo en las aulas: STEDH Lautsi c. Italia de 18 de marzo de 2011).

Ciertamente, y al margen de otras cuestiones espinosas (entre otras, maternidad subrogada -STEDH Paradiso y Campanelli c. Italia de 24 de enero de 2017-), los Estados miembros tienen asumido que algunas sentencias del TEDH han proyectado un impacto constitucional apreciable (piénsese en el reproche al monopolio público radiotelevisivo a través de la STEDH Informationsverein Lentia y otros c. Austria de 24 de noviembre de 1993, o en la modulación del sistema de democracia mediante la STEDH Vogt $c$. Alemania de 26 de septiembre de 1995). Dicho lo cual, podría argüirse que el margen de apreciación nacional es, salvando las distancias, el correlato de la interpretación evolutiva. Si en la interpretación evolutiva se pone el acento en el desarrollo del reconocimiento de los derechos, en el margen de apreciación adquieren prioridad las cláusulas limitativas previstas por el propio CEDH.

No obstante, esa asunción del rol de «jurisdicción constitucional europea» que juega en ocasiones el TEDH (lo mismo que sucede con el TJUE) y que ha generado cierta tensión en el diálogo entre ambas Cortes Europeas y los Tribunales Constitucionales nacionales (los cuales han fraguado teorías como la de los «contra-límites» —especialmente las jurisdicciones constitucionales italiana y alemana-, o nociones como las de «reserva constitucional» o «identidad constitucional» — por ejemplo, el Consejo Constitucional francés-), ha hecho aflorar asimismo ciertos recelos políticos en los Estados miembros.

Buena prueba de esto último viene suministrada por la adopción en 2013 del Protocolo n. ${ }^{\circ} 15$ (firmado por España el 24 de junio de 2013, pero todavía no ratificado a fecha 20 de marzo de 2018), el cual vino a reformar el CEDH para introducir en su Preámbulo una referencia explícita al principio de subsidiariedad y a la doctrina del margen de apreciación que venía propugnada en la Declaración de Brighton (suscrita tras la conferencia celebrada en dicha ciudad los días 19-20 de abril de 2012 y que dio seguimiento a las previas Conferencias de Interlaken de 18-19 de febrero de 2010 y de Izmir de 26-27 de abril de 2011). En otros términos, en la agenda política de los Estados miembros ha estado presente en los últimos años su preocupación por delimitar los perfiles jurisdiccionales del TEDH para (según el informe explicativo del Protocolo n. ${ }^{\circ} 15$ ) «reforzar la transparencia y la accesibilidad de esas características del Convenio y guardar coherencia con la doctrina del margen de apreciación tal como ha sido desarrollada por el Tribunal en su jurisprudencia».

Se percibe, en esas referencias a la transparencia y la accesibilidad, una inquietud en los Estados miembros del Consejo de Europa, precisamente por salvaguardar el principio constitucional de la seguridad jurídica, de saber a qué atenerse ante el ejercicio de su jurisdicción por el TEDH. De hecho, ese valor constitucional de la seguridad jurídica, en tanto que exponente esencial del Estado de Derecho, es al tiempo valor europeo presente en el CEDH. Por tal razón, al ponderar el alcance de las restricciones, formalidades o limitaciones previstas por el CEDH, el TEDH ha acudido en su tarea hermenéutica (para legitimarlas o no) a la noción conexa de «margen de apreciación nacional». Así, ese margen lo ha hallado justificado en preceptos constitucionales (STEDH Gitonas y otros c. Grecia de 1 de 
julio de 1997), en normas no escritas (de common law en la STEDH Sunday Times c. Reino Unido de 26 de abril de 1979, o de derecho consuetudinario stricto sensu — costumbre andorrana- en la STEDH Drozd y Janousek c. Francia y España de 26 de junio de 1992), en códigos deontológicos (STEDH Barthold c. Alemania de 25 de marzo de 1985), o incluso en otras disposiciones internacionales (STEDH Groppera Radio y otros c. Suiza de 28 de marzo de 1990). En contrapartida, cuando ha comprobado insuficiencia o falta de previsibilidad en la legislación interna, ha declarado la violación del CEDH (es conocida la jurisprudencia europea sobre la legislación de enjuiciamiento criminal y las escuchas telefónicas desde la STEDH Valenzuela Contreras c. España de 30 de julio de 1998 u otras posteriores como la STEDH Prado Bugallo c. España de 18 de febrero de 2003).

De todos modos, para completar la respuesta, cabe agregar que la completa certeza con relación a la jurisprudencia del TEDH resulta una quimera si se pretende predecir absolutamente el alcance de su labor hermenéutica, por lo que ni siquiera la entrada en vigor del Protocolo n. ${ }^{\circ} 15$ evitará que se sigan produciendo recelos políticos por las Partes Contratantes o dificultades en el diálogo con los Tribunales Constitucionales. En análogo sentido, el «self-restraint» manifestado por el TEDH en su «doctrina Bosphorus» (consistente en la presunción «iuris tantum» de conformidad del Derecho de la UE con respecto al CEDH -vid. STEDH Bosphorus Hava Yollari Turzim ve Ticaret Anonim Sirketi c. Irlanda de 30 de junio de 2005) no conjura totalmente el riesgo de «dos verdades europeas» con contenciosos paralelos (y posibles soluciones divergentes) en las Cortes de Estrasburgo y de Luxemburgo. De ahí la necesidad de la adhesión de la UE al CEDH (prevista en el Protocolo n. ${ }^{\circ} 14$ e impuesta por el Tratado de Lisboa de 2007) pero, pese a todo, repárese en la difícil articulación de las dos instancias europeas y los recelos que se perciben en el Dictamen 2/13 del TJUE de 18 de diciembre de 2014 (y en el precedente Dictamen 2/94 de 28 de marzo de 1996).

\section{CARLOS RUIZ MIGUEL}

La construcción del llamado «margen nacional de apreciación» se hizo en los primeros momentos de la jurisprudencia del TEDH, ya al menos desde la sentencia «De Wilde, Ooms and Versyp» de 1971. En un inicio fue una construcción que pretendía evitar que el TEDH se excediera en sus funciones. Se trataba de una técnica que pretendía formalizar la «deferencia» mostrada hacia el Derecho nacional y los poderes del Estado miembro. Sin embargo, esa técnica que tenía unos perfiles bien diseñados en los primeros años de funcionamiento del TEDH se ha convertido en una cáscara vacía o, lo que es peor, en un recurso arbitrario. En efecto, la evolución de la jurisprudencia del TEDH muestra que ya pocos años después de formular esta doctrina el propio Tribunal la ignoró en su sustancia, por más que retóricamente la invocara. De acuerdo con la doctrina del «margen nacional de apreciación», cuanto menos uniforme fuera en Europa la comprensión del fin legítimo perseguido mayor sería el poder de apreciación de las autoridades del Estado y menor el nivel de control europeo pues no podría imponerse por el tribunal europeo una forma de entender ese fin si previamente no existiese una noción europea del mismo. El propio Tribunal consideró que la invocación de la «moral» como límite de algunos derechos se englobaba en ese tipo de fines. Y, sin embargo, muy pocos años después de formulada la doctrina del «margen nacional de apreciación» el TEDH pronunció varias 
sentencias que afectaban a la «moral» (por ejemplo, en relación con la homosexualidad y la transexualidad) donde a pesar de ser notorio que no existía una noción europea común de ese fin el Tribunal desestimó que correspondiera a las autoridades nacionales la consideración del alcance que ese fin tuviera para determinar el límite de algunos derechos reconocidos en el Convenio. Si esto ocurrió ya en sentencias de la década siguiente (los ochenta) a la formulación de esa doctrina, no es difícil ver que eso mismo (con muy escasas excepciones) ha seguido ocurriendo en las décadas siguientes. La conclusión, a mi juicio, es que en este momento no hay una previsibilidad suficiente acerca de cuándo el TEDH además de invocar el «margen nacional de apreciación» realmente va a mostrar deferencia ante los tribunales nacionales.

Parece evidente que el uso que hace el TEDH de la doctrina que él mismo construyó no resulta satisfactorio para los Estados parte del Convenio. De ahí que el Protocolo número 15 (firmado el 24 de junio de 2013, pero aún no en vigor) haya propuesto añadir un considerando al final del Preámbulo del CEDH para positivizar el «margen nacional de apreciación» como consecuencia del «principio de subsidiariedad» ${ }^{6}$. Sin embargo, no parece claro que esta mera inclusión en el Preámbulo del CEDH pueda ser un freno eficaz para el activismo del TEDH.

\section{ROSARIO TUR AUSINA}

Como es conocido, la doctrina del margen de apreciación nacional es un criterio hermenéutico clásico por el que los Tribunales supranacionales muestran su deferencia hacia los Estados y les dejan a estos su propio espacio en la compleja construcción de un acervo constitucional común. Aunque esta doctrina nace a partir del art. 15 del Convenio, relativa al derecho de derogación en caso de urgencia y que permite la suspensión de derechos en razón de un peligro público, ha ido perfilándose hasta conectarse con el principio de subsidiariedad y convertirse — en ello se está todavía - en un importante instrumento para el diálogo.

Pero la doctrina del margen de apreciación no se entiende sin el principio de subsidiariedad, que no supone sin más que sean los niveles inferiores — los Estados— quienes configuren los derechos del convenio. En realidad, desde el pluralismo, se trata más bien de construir la Europa de los Derechos en un continuo proceso de interacción con las instancias supranacionales, pues los garantes naturales son los Estados mismos, en una búsqueda de una tutela real y efectiva - y no meramente ilusoria- de los derechos para la que se necesita que la ciudadanía y las instituciones mismas comprendan, asuman e interioricen ese sistema compartido de libertad e igualdad. Porque la imposición —o la simple percepción de la misma- de ciertas decisiones por instancias superiores sin comprenderse bien el sistema que se comparte, acaba haciendo volar por los aires su funcionamiento armónico y eficaz, como se observa después en incumplimientos claros y rotundos a veces, torticeros, desviados, parciales, o forzados, en otros.

6 «Affirmant qu'il incombe au premier chef aux Hautes Parties contractantes, conformément au principe de subsidiarité, de garantir le respect des droits et libertés définis dans la présente Convention et ses protocoles, et que, ce faisant, elles jouissent d'une marge d'appréciation, sous le contrôle de la Cour européenne des Droits de l'Homme instituée par la présente Convention». 
De este modo, la doctrina del margen de apreciación ha querido convertirse en una especie de oportunidad para los Estados de opinar sobre su mismo sistema -inserto en una realidad compleja—, con su propia percepción — que por naturaleza les legitima-, y siendo participes directos y no solo meros receptores. Sujetos activos y no pasivos para apreciar e interpretar su propia legalidad, contribuyendo a concretar el propio Convenio de Roma con el estándar nacional a partir de los espacios que deja Estrasburgo. No se pierde, así, la parte de liderazgo último, que no monopolio, que corresponde a cada Estado.

Ahora bien, aunque son muchos los elementos positivos de esta doctrina, sobre la misma también ponemos el énfasis en tres grandes aspectos problemáticos.

En primer lugar, el hecho de que la doctrina del margen de apreciación se entrecruza con la excepcionalidad constitucional, que podría llevar a las autoridades nacionales a legitimar diversas acciones para proteger el sistema democrático y, con ello, suspender/ restringir derechos, pues son aquellas, en uso de su soberanía, las especialmente idóneas para valorar las situaciones que amenazan la estabilidad del país (Lawles c. Irlanda, de 15 de noviembre de 1960; Handsyside c. Reino Unido, de 7 de diciembre de 1976). No parece, sin embargo, que sea esta la línea por la que ha acabado transitando el uso del margen de apreciación, en una legitimación sin más de la excepcionalidad constitucional convertida en lo común, pues ello querría decir que el Tribunal se sitúa en un plano ajeno al que es su misión, la convivencia pacífica a partir de su contribución a un sistema democrático de convivencia. Afortunadamente, la doctrina del margen de apreciación ha ido perfilándose hacia parámetros más garantistas, pues su uso tiene lugar cuando existe una notable divergencia en aspectos sensibles. Y es que esta doctrina no debe ser vista ni puede convertirse nunca en una dejación de funciones, pues es un instrumento colaborativo que no sólo sirve para los casos en que no existe un consenso interestatal (aunque suele utilizarse este argumento como central en la justificación del margen de apreciación), sino precisamente para construirlo y avanzar en las garantías de los derechos junto con los Estados. Porque, como advierte Barbosa, el margen funciona correctamente solo a partir de una condición: que los Estados ofrezcan suficientes garantías sobre el respeto escrupuloso del Estado de Derecho y de los parámetros democráticos (Barbosa, El margen nacional de apreciación en el derecho internacional de los derechos humanos: entre el Estado de Derecho y la sociedad democrática, 2012). En caso contrario, si falla la democracia estatal, es cuando el TEDH no puede permanecer impasible ya que, entonces sí, estaría dejando de servir a los fines previstos en el Convenio de Roma.

En segundo lugar, un hándicap adicional lo constituye el hecho de que la doctrina del margen de apreciación es, por definición oscilante, pues se construye a partir del casuismo característico de cualquier jurisdicción constitucional de la libertad, la cual combina la dimensión subjetiva — la atención a los específicos casos que se le plantean-, con la dimensión objetiva - el enjuiciamiento en abstracto o de fondo de todo un sistema político o partes del mismo, con el fuerte grado de politización que ello puede conllevar- Sin embargo, esto no debe constituir un problema, pues solo impone un mayor esfuerzo por incrementar la carga argumentativa de sus resoluciones, y acciones que refuercen el conocimiento y formación en el constitucionalismo multinivel, así como el diálogo entre instancias.

Pero en tercer lugar, a nuestro juicio un auténtico reto representa el tercero de los problemas, que se produce cuando el margen de apreciación es entendido como estándar máximo, y no mínimo (Rodríguez, «La mayor protección interna de los derechos de la 
Convención Europea de Derechos Humanos y el impacto del margen de apreciación nacional», $R D P, 2015)$. Es decir, el margen de apreciación nacional en un litigio que afecta a un concreto Estado, no debería suponer, sin más, que ese estándar es aplicable al resto de Estados, pues es posible que estos tengan al respecto, o bien un estándar constitucional diverso - llegando a las mismas conclusiones pero por distintos motivos-, o incluso más elevado. Pero es que, además, ello es así precisamente en virtud del principio de subsidiariedad que informa la propia doctrina del margen de apreciación, y que determina el respeto debido a las instancias nacionales para continuar configurando (y elevando) su propio estándar constitucional, en diálogo, eso sí, con las instancias supranacionales, dado que el marco constitucional multinivel es un proyecto compartido, en red, que exige el respeto al principio de lealtad constitucional.

Sin ánimo de hacer ahora una recopilación exhaustiva, baste con citar los casos Lautsi c. Italia, sobre presencia de simbología religiosa en las aulas (Sentencias de 18 de marzo de 2011 — Gran Sala_, y 3 de noviembre de 2009 — Sala_-), o diversos litigios relativos a la disolución e ilegalización de partidos políticos, que es admitida por la doctrina de Estrasburgo, no solo por las actividades antidemocráticas, sino también por los fines o las ideologías políticas también contrarias a la democracia, siempre que exista una necesidad imperiosa para ello (Refab Partisi c. Turquía, de 31 de julio de 2001 - Sala_, y 10 de febrero de 2003 - Gran Sala_; Partido del Trabajo del Pueblo c. Turquía, de 9 de abril de 2002, entre otras). Casos que evidencian que la doctrina de Estrasburgo no necesariamente ha de ser aplicable de modo automático por nuestros tribunales, pues el estándar español es a nuestro juicio en estos casos más alto por sustentarse en un acervo constitucional diverso a los sistemas políticos enjuiciados por Estrasburgo.

De hecho, en estos supuestos y con esta dinámica se corre el riesgo de generar un cierto involucionismo europeo, pues se daría la paradoja de que con la aplicación automática por las instancias nacionales del estándar configurado por Estrasburgo y que ha sido interpretado como máximo, se llegara a una reducción inconcebible de la tutela constitucional estatal. Se perdería así la posibilidad de ir construyendo estándares estatales más altos, paulatinamente compartidos, y que luego acaben siendo acogidos por las decisiones de Estrasburgo para hacerlas finalmente extensibles a todos los Estados cuando existiera un consenso aceptable.

El constitucionalismo multinivel no representa la construcción por las instancias nacionales de su propio canon interpretativo al margen de su propia realidad constitucional y con la aceptación automática de las resoluciones de Estrasburgo en otros casos, sino dialogando precisamente para señalar los Tribunales en sus resoluciones por qué no resulta aplicable su doctrina. Y es que precisamente de dicho auténtico diálogo debería nacer una ulterior respuesta de la instancia supranacional; porque dialogar no es, en efecto, aceptar sumisamente lo que dice el otro ni tampoco obviarlo, sino hacer suyo el planteamiento del otro para, mediante una nueva argumentación, construir una verdad compartida. Son los Estados, en el ejercicio de la más plena convivencia democrática, quienes han de construir su propio canon interpretativo elevando incluso, en la medida de su tradición, los propios estándares de Estrasburgo. Porque el hecho de que una instancia supranacional deje hacer, no implica asumir futuras lesiones de derechos contrarias al propio estándar constitucional, lo cual tendría tintes paternalistas e iría en contra, precisamente, de la madurez que la organización supranacional exige al Estado. Se necesita cultura multinivel y comprensión, precisamente, del encaje que supone la jurisdicción de 
Estrasburgo en los sistemas nacionales. Ahora bien, esto tampoco significará que el Tribunal Europeo pueda verse arrastrado por las inercias de los Estados y muestre una cierta debilidad ante ciertas presiones. La sensibilidad de ciertos temas nacionales o, precisamente, una falta de diálogo, puede llevar a que la instancia supranacional claudique de posicionamientos garantistas cuando se le sitúa en una zona difusa en la que entran en conflicto intereses estatales y ciertos posicionamientos garantistas derivados del Convenio. Es sólo en este caso, precisamente, cuando estaría en riesgo de quiebra la seguridad jurídica, a la que ya nos hemos referido.

$Y$ es que en la dinámica multinivel conviene no pecar de ingenuidad, para asumir que el fin natural de los poderes que operan —y por ende del derecho—, no es la justicia social sino el control y el juego por el poder mismo, a través de relaciones de dominio que se sitúan en la base misma de las normas jurídicas. Pero porque se trata, precisamente, de racionalizar la violencia humana, se necesita que el TEDH siga contribuyendo de forma serena y atenta a alimentar el pacto de convivencia europeo. En resumidas cuentas, los fines humanos - la libertad, la igualdad, los derechos, la dominación, los privilegios,...- , son una consecuencia y no la causa ni la razón de la fundamentación racional supranacional. Y esto significa que la identidad constitucional, globalizada ya de forma irremediable, habrá que buscarla, pues difícilmente vendrá sola.

5. ¿Cuál es su opinión sobre las recomendaciones del TEDH a los Estados? ¿Y sobre las sentencias piloto?

\section{ENOCH ALBERTÍ ROVIRA}

La introducción a partir de 2004 de las sentencias piloto (o, más bien, de los procesos piloto, en la medida que pueden abarcar en realidad diversas actuaciones del TEDH, que incluyen también el control, junto con el Comité de Ministros, de las medidas generales adoptadas por el Estado demandado e incluso las reclamaciones individuales presentadas de nuevo ante el TEDH por considerar que tales medidas son insuficientes y se siguen vulnerando los derechos reconocidos en el CEDH, como ya se puso de manifiesto en el caso Broniowski v.Polonia que inició este tipo de actuaciones) marcan sin duda un hito importante en la evolución del TEDH como instrumento de protección de los derechos en el ámbito europeo y suponen un salto cualitativo en su función, no exento sin embargo de algunos problemas.

Por una parte, se reconoce en general que la técnica de los procesos piloto se justifica por la ingente carga de trabajo del TEDH, que lo desborda (63.350 demandas en 2017). Ello conduce necesariamente no solo a acumular casos semejantes, sino también a seleccionar, en función de la entidad del derecho vulnerado y de su trascendencia (del derecho, de la vulneración y de su significado respecto de la propia Convención) y también de lo que podríamos llamar la carga potencial de conflictividad de los asuntos planteados, eso es, las nuevas demandas que potencialmente podrían originarse en el futuro si no se resuelve la fuente de la vulneración. Sobre este último extremo no hay que olvidar que en el caso Broniowski había 176 casos pendientes ante el Tribunal, pero sobre todo unos 80.000 casos potenciales por el mismo motivo. Pero no se trata de una motivación sólo práctica la que 
mueve esta línea de actuación del TEDH (y que, a otra escala, es posible apreciar también en otros altos tribunales, como el TC español, cuya LO se reformó para que pudiera seleccionar los recursos de amparo por su transcendencia constitucional). En esta evolución puede apreciarse también una mayor implicación del Tribunal en la efectividad de sus sentencias y en la protección efectiva de los derechos del Convenio en todo su territorio de aplicación, enormemente ampliado, contribuyendo a crear un orden público europeo basado en el respeto de los derechos fundamentales y las libertades públicas. La conjunción de ambos factores genera una tendencia hacia la transformación del papel del TEDH en la protección de los derechos del Convenio, pasando de la clásica protección individual y concreta para la que fue concebido a una protección de carácter más objetivo, centrada en evitar las vulneraciones de derechos en origen, en su propia fuente. Este tipo de actuación, que no está prevista en el Convenio pero que los Estados han aceptado implícitamente, hace que el papel del TEDH se asemeje al de los tribunales constitucionales, que pueden controlar las fuentes de vulneración de los derechos, especialmente si provienen de la ley, y no solo establecer su reparación, aunque lo hagan de un modo distinto a cómo lo hacen los tribunales constitucionales. Ello sin duda redunda en una protección más eficaz del régimen de derechos en Europa y contribuye, como decía, a crear y fortalecer un orden público europeo basado en los derechos fundamentales.

Pero por otra parte, el hecho de que cuando se inicia un proceso piloto se suspenda la tramitación de las demandas semejantes ya presentadas ante el TEDH, e incluso que la que se ha tomado como referencia piloto se demore hasta que el Estado demandado adopte las medidas generales que corrijan los defectos de su ordenamiento que han provocado la vulneración (los problemas estructurales o sistémicos, en expresión del TEDH), supone rebajar, al menos inicialmente, la protección concreta e individual de las personas que plantearon sus demandas ante el TEDH, que no solo quedan diluidas en unas medidas generales, sino que ven cómo se retrasa la resolución de sus asuntos e incluso pueden verse obligados a litigar de nuevo (ante las instancias nacionales o ante el propio TEDH) para el caso de que las medidas generales adoptadas por el Estado no les satisfagan. Esto, no obstante, no es nada nuevo, pues es un conflicto, o al menos una tensión que se produce siempre cuando a través de un mismo instrumento debe dispensarse una protección subjetiva o individual y, a la vez, una protección objetiva o general. Y normalmente, el acento acaba cargándose hacia la protección objetiva.

Esta cuestión, en el caso del TEDH, se mezcla además con otro debate, de carácter general. Porque además de poner en cuestión, creo que justificadamente, la visión originalista del TEDH como instrumento de protección exclusivamente individual de los derechos, que tiene vedado controlar, objetivamente, la legislación de los Estados y que no puede dirigirle indicaciones sobre medidas generales para corregirla, entra también en el terreno, siempre pantanoso, de la función de los tribunales como legisladores positivos. En el fondo, sin embargo, se constata que los problemas con los que se enfrenta el TEDH, o al menos una parte importante de ellos, tienen mucho que ver con los propios de los tribunales constitucionales. Ello es síntoma de la emergencia de lo que se ha denominado como dimensión constitucional del TEDH, y, más allá incluso, de la función constitucional que va desempeñando el CEDH. E ilustra también los límites de esta función constitucional.

Porque, en efecto, hay que poner los procesos piloto en el contexto de todas las sentencias dictadas por el TEDH. Se constata así que sólo algunas pocas de ellas son 
sentencias piloto (el propio TEDH relaciona solo 26 sentencias piloto desde su inicio en 2004 hasta finales de 2017, aunque, naturalmente, éstas resuelven un número mucho mayor de casos, tanto presentados como potenciales en el futuro). No puede menospreciarse su significado cualitativo y su valor como síntoma de una tendencia muy poderosa, pero ello no ha anulado ni impedido que el TEDH siga desempeñando, eso sí, con muchas dificultades, debidas en gran parte al número ingente de casos presentados, su papel de protección concreta e individual de los derechos frente a los Estados, que siguen gozando de una amplia libertad para elegir los medios para reparar las vulneraciones producidas y evitar que se produzcan en el futuro. Como tampoco debe perderse de vista que la simple existencia de esta técnica de actuación por parte del Tribunal puede tener efectos respecto de los Estados, sin duda de difícil cuantificación e incluso apreciación, pero que pueden provocar que éstos se vean más impelidos a tomar medidas generales que remedien posibles vulneraciones de derechos reconocidos en el $\mathrm{CEDH}$ ante la posibilidad de que el TEDH considere tratar un recurso como proceso piloto, y más aún desde que su codificación en la Regla 61 del Reglamento del Tribunal, en 2011, no exige que exista una pluralidad de recursos sino que basta con uno solo que revele la existencia de un problema estructural o sistémico que pueda dar lugar a recursos similares.

\section{JUAN MARÍA BILBAO UBILLOS}

En líneas generales, me parecen pertinentes las recomendaciones del Tribunal cuando la causa de la violación que ha constatado en su sentencia es una carencia o deficiencia normativa o una mala praxis administrativa o judicial.

En cuanto a las «sentencias piloto», el Tribunal ha desarrollado en los últimos años un nuevo procedimiento para dar respuesta al flujo masivo de demandas sobre problemas similares, sistémicos, porque tienen su origen en una inadecuación del ordenamiento interno al Convenio. El TEDH selecciona una o algunas de las demandas que ponen al descubierto el problema estructural, posponiendo casi siempre el examen de los demás asuntos (repetitive applications) que obedecen a la misma causa. La sentencia piloto sirve como referente en la resolución de un elevado número de casos análogos o clónicos, ya planteados o que pudieran plantearse en el futuro. Se diluye la dimensión individual del recurso, porque la situación denunciada no afecta exclusivamente al demandante. Por eso, en lugar de limitarse a declarar la violación del derecho del demandante, exhorta a las autoridades a adoptar una serie de medidas destinadas a solventar el problema sistémico subyacente, medidas que implican muchas veces un coste económico. Al dictar la sentencia, el Tribunal invita al Gobierno condenado a adaptar su legislación o sus prácticas al Convenio indicándole las medidas concretas a adoptar para corregir esa deficiencia estructural. Puede fijar incluso un plazo para la adopción de esas medidas.

Se suele presentar esta modalidad procesal como una creación jurisprudencial y es verdad que no está prevista en el Convenio ni en el Protocolo n. ${ }^{\circ} 14$, pero se inspira directamente en dos resoluciones del Comité de Ministros aprobadas en 2004. La primera de ellas es la Recomendación (2004)6 «sobre la mejora de los recursos internos» en la que se exhorta a los Estados a revisar, cuando las sentencias del Tribunal apuntan la existencia de fallos 
estructurales, la efectividad de los recursos internos existentes y a establecer, si fuese necesario, recursos efectivos, a fin de evitar la presentación de casos repetitivos ante el Tribunal. De la misma fecha es la Resolución (2004)3 «sobre las sentencias que revelan un problema estructural subyacente», que insta al Tribunal a identificar en sus sentencias las causas que provocan violaciones generalizadas del Convenio.

No es casualidad que un mes después de la aprobación de estas resoluciones se dictase la primera sentencia piloto. En efecto, se recurre por primera vez a esta técnica en el caso Broniowski c. Polonia (2004), en la que se constata que la violación denuncia tiene su origen en un "problema sistémico» (en este caso, la ausencia de un recurso efectivo para reclamar el restablecimiento del derecho de propiedad infringido). Se ha empleado frente a problemas endémicos, como malas condiciones de prisiones (Ananyev y otros c. Rusia, 2012; y Torreggiani y otros c. Italia, 2013); la duración de los procesos judiciales (Rumpf c. Alemania, 2010); o exclusión legal del sufragio de las personas condenadas a penas privativas de libertad (Greens y M.T. c. Reino Unido, 2010)

Lo cierto es que desde su estreno en 2004 las flamantes «sentencias piloto» han seguido un curso ascendente, con una potencia de fuego nada despreciable. Es una técnica consolidada. Aunque este modus operandi del Tribunal de Estrasburgo no obedece a las mismas razones que permiten explicar el surgimiento y la evolución de las sentencias dictadas por algunos Tribunales nacionales, como la Corte Constitucional colombiana (el amparo estructural como respuesta a un «estado de cosas inconstitucional»). Su razón de ser no es seguramente la voluntad de abrir una puerta a la intervención en asuntos políticos, sino más bien la necesidad de hacer frente a la congestión de asuntos pendientes mediante un expediente que tiene todo el sentido en pura lógica procesal. Se trata, en último término, de facilitar una más rápida y eficaz ejecución de las sentencias, evitando el planteamiento de casos repetitivos (con fundamento en los mismos hechos)

Pese a que el Convenio no faculta al Tribunal para emitir este tipo de fallos, lo cierto es que ha pasado a formar parte de la batería de herramientas a disposición del Tribunal y las autoridades nacionales se han mostrado receptivas y dispuesta a acatar ese tipo de requerimientos. No han opuesto al menos una especial resistencia, si exceptuamos el caso del Reino Unido. Se ha visto obligado a acudir a este remedio heterodoxo para garantizar una protección más efectiva de los derechos.

Esta técnica suscita algunos interrogantes sobre su fundamentación jurídica y su legitimidad democrática. Se cuestiona sobre todo su compatibilidad con un modelo que se basa en el principio de subsidiariedad, en cuya virtud son los Estados los responsables de garantizar dentro de sus fronteras el respeto de los derechos consagrados en el Convenio y adoptar las medidas necesarias para el pleno restablecimiento de los derechos infringidos. En ese diseño institucional no tienen fácil encaje. Como puso de relieve el Juez Zagrebelsky en la opinión disidente que emitió en el asunto Hutten-Czapska c. Polonia (2006), las sentencias piloto socavan, por un lado, la relación entre los dos pilares del sistema del Convenio, el Tribunal y el Comité de Ministros, al otorgar a aquel funciones que no le corresponden, y por otro, propician la intervención del Tribunal en el campo de la política interna de los Estados, lo que constituye una clara extralimitación. El riesgo de cruzar la línea y suplantar al legislador o al ejecutivo del Estado demandado en el diseño y la ejecución de políticas públicas existe y no se puede infravalorar, pero a la luz de la experiencia acumulada en estos años creo que el Tribunal no se ha excedido en el uso de esta técnica. 


\section{VÍCTOR FERRERES COMELLA}

Cuando los tribunales que velan por los derechos humanos no se limitan a garantizar unas exigencias mínimas relativamente claras, sino que tienen que resolver cuestiones controvertidas, suelen tener a su disposición una caja de herramientas bastante compleja. Las recomendaciones forman parte de la variedad de técnicas que los tribunales pueden utilizar legítimamente, siempre que hagan un uso moderado de las mismas. También los tribunales constitucionales han recurrido a ellas en ocasiones. A mi entender, las críticas que se han formulado al respecto, en nombre de la separación de poderes o el principio democrático, son exageradas. En cuanto a las sentencias piloto, parece claro que el TEDH necesitaba contar con un instrumento eficaz para dar respuesta a problemas estructurales en determinados Estados. Así, en el asunto Broniowski contra Polonia (sentencia de 22 de junio de 2004), en el que el TEDH utilizó por primera vez este tipo de remedio judicial, el problema estructural de violación de derechos humanos afectaba a unas 80.000 personas. Es razonable que se potencie este mecanismo de tutela general de los derechos en el marco del Consejo de Europa.

\section{JAVIER GARCÍA ROCA}

El procedimiento de las sentencias piloto (pilots judgements) nació como una una buena práctica y respuesta judicial a las largas series de demandas repetitivas provocadas por defectos estructurales en los diversos ordenamientos nacionales, o por irregularidades o disfunciones derivadas de una misma disposición general. De alguna manera, permite objetivar el amparo europeo y reconducir el problema de la tutela de los derechos a las leyes con cierta generalidad. Ésta es su principal virtud, pero también permitir rebajar el elevado número de demandas pendientes de enjuiciamiento y alcanzar la colaboración como veremos - de los Estados miembros.

Fue el propio Comité de Ministros quien impulsó esta técnica con su resolución sobre sentencias en las que subyacen problemas estructurales o sistemáticos (Resolución Res (2004) 3 , de 12 de mayo de 2004). Se invitaba allí al Tribunal Europeo a identificar las causas estructurales de las violaciones del Convenio en numerosas demandas, y se pedía que se notificara la decisión no sólo al Estado demandado sino a la Asamblea parlamentaria, al Secretario General del Consejo de Europa y al Comisionado de Derechos Humanos. En la misma sesión, de forma complementaria, se aprobó una Recomendación Rec (2004) en la que se instaba a los Estados a mejorar los remedios nacionales, para a asegurarse de que antes existiera un recurso efectivo en sus ordenamientos. Obsérvese que sentencias piloto o revisión de las leyes y mayor subsidiariedad como contrapeso han ido de la mano por paradójico que pueda resultar.

Estas resoluciones y recomendaciones del Comité inauguraron una nueva fase en la jurisdicción europea, que estimo la aproxima a las jurisdicciones constitucionales que tienen como función definitoria el control de las leyes de forma abstracta. Se superaba — sin abandonarlo_ - el tradicional escenario de las compensaciones o satisfacciones equitativas y la solución de pequeñas demandas individuales, para aproximarse al control abstracto de convencionalidad de las leyes, lo que sin duda refuerza la vinculación y eficacia de las sentencias del TEDH a las que difícilmente podrá seguir considerándose como 
declarativas. De aquí la importancia de esta técnica que probablemente transformó la naturaleza de la jurisdicción europea. Su impacto es mucho más grande de lo que a primera vista parece.

Se corrobora en la práctica con este instrumento la tesis que vengo defendiendo entre nosotros en sede teórica — siguiendo propuestas de Lech Garlicki y Andrea Vobkhule- desde hace tiempo: la necesidad de trasladar categorías del sólido y clásico Derecho Procesal Constitucional europeo al nuevo y emergente Derecho Procesal Convencional.

Tras comenzar a andar por este sendero, no obstante, el Reglamento del TEDH no fue modificado hasta 2011 para regular un procedimiento de sentencias piloto en su artículo 64. Se identifican los supuestos, como ya he explicado, y se pide al Tribunal que antes de tramitarlo pregunte la opinión de las partes acerca de si concurre un problema estructural o sistémico. Pero también las partes pueden pedir por si mismas el inicio del procedimiento que no sólo puede abrirse de oficio. Son procedimientos prioritarios o de tramitación preferente. El Tribunal selecciona una o varias demandas de entre un número de demandas repetitivas, y debe en la sentencia piloto identificar la naturaleza de la disfunción o problema, y las medidas para repararlo que se pide al Estado parte que adopte. Puede incluso señalarse un plazo de tiempo para hacerlo y delimitar la urgencia del asunto. Es importante recordar que, después de una sentencia piloto y mientras se ejecuta, la Corte puede suspender la decisión de otras demandas similares y la concesión de justas satisfacciones, informando a las partes de lo que ocurre. Se auspicia asimismo alcanzar acuerdos amistosos al tiempo del desarrollo y la ejecución de las medidas pedidas e incluso cabe repatriar la solución de las demandas a los Estados una vez conseguido un procedimiento y unas reparaciones a nivel nacional. Para propiciar la transparencia y la eficacia, el TEDH debe dar información sobre estos casos piloto en su web e informar a las demás instituciones del Consejo de Europa. Una regulación sencilla, pero consistente y me parece que bastante eficaz.

Esta «repatriación» con ciertas garantías de las demandas repetitivas tras una sentencia piloto contribuye seriamente a rebajar el estado de los asuntos pendientes en Estrasburgo y asimismo refuerza la subsidiariedad, permitiendo dictar soluciones más rápidas por las autoridades nacionales. Poco puede objetarse si la colaboración entre autoridades europeas y nacionales se produce con lealtad.

La sentencia emblemática de la nueva línea fue el conocido Caso Broniowsky contra Polonia, de 22 de junio de 2004, referido a las llamadas propiedades del río Bug, que afecta a muchos millares de personas, y que hemos comentado - véase Mar Aguilera y Anna Margherita Russo_ con detalle en el libro ¿Hacia una globalización de los derechos..?, así como las decisiones posteriores del Gobierno y el Tribunal Constitucional polaco para implementarla. El Tribunal Europeo declaró la violación del artículo 1 Protocolo 1 , porque después de la II Guerra Mundial miles de propietarios quedaron abandonados a su suerte al cambiar la frontera que se trazó más allá del río Bug, no pudiendo ya disfrutar sus posesiones y sin recibir indemnización alguna. La regulación polaca de los años ochenta y noventa concedía compensaciones, pero albergaba un amplio número de limitaciones que dificultaban sobremanera percibir unas indemnizaciones que eran, por otra parte, irrisorias. La sentencia piloto afectaba a un elevado número de personas y su implementación reclamaba numerosos cambios legislativos, judiciales y administrativos. Por primera vez, el TEDH indicó claramente en una sentencia numerosas medidas generales 
de reparación que el Estado demandado debía seguir bajo la supervisión del Comité de Ministros; es una nueva muestra de colaboración en la reparación y la ejecución entre los órganos judicial y político del sistema del Convenio a la que al contestar otras preguntas me he referido.

No obstante, en el homenaje del año pasado en la Universidad de Varsovia al Juez polaco del TEDH, Lech Garlicki, con motivo de presentarse su Liber amicorum, publicado en inglés, tuve oportunidad de informarme sobre el terreno acerca de lo difícil que está siendo, en la realidad, dar una solución eficaz a las situaciones individuales dada la contraposición de los intereses generales y privados en conflicto y la complejidad del asunto, así algunas empresas se han hecho con la titularidad de las propiedades privadas a precios irrisorios y se encargan de las negociaciones. Las sentencias piloto no pueden hacer milagros. Pero estas dificultades me parece que en nada objetan la bondad de la nueva técnica y procedimiento.

Por lo demás, la técnica de las sentencia de recomendación es una variante habitual de las sentencias constitucionales interpretativas en Alemania, Italia y España, que no suele ser censurada por sus estudiosos por más que no siempre sean seguidas y su eficacia sea menor que la declaración de invalidez que no siempre será posible. Pero las sentencias piloto no entrañan meras «recomendaciones» al legislador, simples consejos de los que pueden obtenerse beneficios, son realmente medidas generales de reparación de la violación del derecho y del daño causado, para restablecer a los titulares de derechos en el goce de los mismos, que resultan vinculantes para el Estado demandado, al igual que el resto de la sentencia, y cuya ejecución puede supervisar y cerrar el Comité de Ministros. Es otra herramienta distinta.

No falta, finalmente, quien ha escrito objetando a las sentencias piloto que transforman al Tribunal Europeo en un legislador. Esta objeción es una vieja crítica habitual en la jurisdicción constitucional y de allí emana la idea, pero no sus razones no son válidas. Son cosas distintas aprobar leyes, normas generales y abstractas, por un Parlamento que dictar un tribunal medidas generales de reparación, aunque lo segundo pueda llevar a lo primero. En modo alguno aminora, como se ha dicho, las situaciones jurídicas individuales de los afectados sino que por el contrario refuerzan su garantía, pues no impiden las medidas individuales de reparación y se fortalecen con las generales que atiende al verdadero origen del problema. Tampoco es evidente que los Estados miembros no vayan a cumplirlas, siempre que resulten viables y razonables, porque ha sido el propio Comité de Ministros, con representación de los Estados, quien con buen sentido ha impulsado el nuevo sistema, y a ningún Estado le halaga ser condenado permanentemente.

\section{LUIS JIMENA QUESADA}

En cuanto a lo primero, con carácter preliminar, entiendo que debería evitarse la noción de «recomendación» al aludir a la actuación jurisdiccional del TEDH. En efecto, el TEDH dicta resoluciones (especialmente, las sentencias en el ejercicio de su competencia contencioso, pero también opiniones cuando ejerce su competencia consultiva) que son vinculantes. Concretamente, la jurisdicción del TEDH, a tenor del art. $32 \mathrm{CEDH}$, «se extiende a todos los asuntos relativos a la interpretación y aplicación del Convenio y de sus Protocolos que le sean sometidos en las condiciones previstas por los artículos 33 , 34, 46 y 47»; o, dicho con otras palabras, el Tribunal ostenta una competencia 
contenciosa para resolver demandas interestatales (art. 33) e individuales (art. 34), incidentes de ejecución (art. 46) y una competencia consultiva (art. 47 -la legitimación activa queda circunscrita al Comité de Ministros del Consejo de Europa).

En este contexto, las medidas de reparación que establece el TEDH en sus sentencias no configuran meras directrices, sino obligaciones que han de ser respetadas y llevadas a la práctica por los Estados condenados en virtud del principio «Pacta sunt servanda» y del efecto útil de las disposiciones convencionales que debe ser procurado de buena fe por las Partes Contratantes. Es cierto que las medidas reparadoras pronunciadas por el TEDH no son tan variopintas como, por ejemplo, las decretadas por la Corte Interamericana, o que el sistema de supervisión de la ejecución de las sentencias y de esas medidas de reparación es diverso en cada sistema (en el interamericano es la propia Corte de San José de Costa Rica quien supervisa, mientras en el sistema europeo se confiere esa tarea principal al Comité de Ministros del Consejo de Europa, incluso a pesar del «plus» de judicialización del procedimiento de ejecución que se introdujo a favor del TEDH mediante el Protocolo n. ${ }^{\circ}$ 14). Y es verdad, asimismo, que el procedimiento de ejecución de las sentencias del TEDH difiere del de las sentencias del TJUE; lo cual entiendo que no implica, dicho sea de paso, que las sentencias del TJUE tengan valor prioritario en caso de divergencia entre ambas jurisdicciones europeas.

Resulta pertinente una breve acotación sobre esto último. Efectivamente, incluso cuando se llega a discernir entre ambas organizaciones europeas, se tiende a otorgar sin más prevalencia al canon de la UE sobre el parámetro del Consejo de Europa en caso de aflorar conflicto interpretativo entre sus instancias máximas respectivas de control (TJUE y TEDH). Semejante proceder (en mi opinión, incorrecto) tiene entre sus causas, sin duda, la catalogación político-constitucional de la UE como entidad supranacional sui generis o como tertium genus entre la Organización internacional clásica y el Estado constitucional, en conexión con el hecho de haber transferido de manera más neta a aquélla el ejercicio de competencias soberanas y la posibilidad de emanar Derecho derivado o secundario que impacta directamente en la ciudadanía. Ahora bien, esta circunstancia, unida a la base habilitante constitucional diversa (en el caso de España) prevista para asumir los instrumentos constitutivos de cada organización internacional (art. 93 CE para la UE, pero no sólo, y art. 94 CE para el Consejo de Europa), no implica que, una vez incorporados los distintos estándares internacionales, unos se pongan por encima de otros en caso de conflicto, que sigue unas reglas (señaladamente, interpretativas) establecidas por la Convención de Viena de 1969 (arts. 31 a 33); bajo cuyo paraguas, por cierto, se encuentra asimismo el Derecho de la UE (vid. art. 5 de la Convención de Viena). Paradójicamente, son las normas de la UE, tanto originarias como derivadas, las que reenvían a las del Consejo de Europa a efectos interpretativos, y no a la inversa.

Consecuentemente, las sentencias del TEDH (y sus medidas de reparación, que ya no son meramente indemnizatorias o pecuniarias, sino que incluyen otras consecuencias, como la puesta en libertad de la persona demandante) no contienen recomendaciones; dicha tarea la lleva a cabo el Comité de Ministros del Consejo de Europa, como puede comprobarse en su Informe Anual sobre la supervisión de la ejecución de las sentencias del TEDH (en donde se recomiendan medidas como la revisión de procedimientos internos, la formación de funcionarios, la traducción de sentencias a otros idiomas no oficiales del Consejo de Europa, etc.). Las disquisiciones doctrinales sobre el valor de las sentencias del TEDH (autoridad de cosa juzgada, cosa interpretada, valor declarativo, valor ejecutivo, 
etc.) no deben enturbiar su indiscutible naturaleza vinculante y, por ende, fase interpretativa y fase aplicativa del CEDH resultan inescindibles para asegurar la ejecución de los pronunciamientos del TEDH.

A mayor abundamiento, la idea de competencia de la competencia del TEDH para supervisar la ejecución o cumplimiento de sus propios pronunciamientos ha ido ganando terreno. Pensemos, en tal dirección, en la extensión de la jurisdicción del TEDH (prevista en el citado art. $32 \mathrm{CEDH}$ ) a través de la consulta introducida mediante el Protocolo n. ${ }^{\circ} 16$ al CEDH (de 2 de octubre de 2013; ni siquiera firmado por España por el momento). Cuando se produzca la vigencia del citado instrumento (conocido como «Protocolo del diálogo»; a fecha 20 de marzo de 2018 contaba sólo con 8 ratificaciones, precisándose 10 para su entrada en vigor), pese a que en este caso la opinión consultiva del TEDH no sea vinculante y, por tanto, no revista obligatoriedad, debería asumirse como tal pues, de lo contrario, tras el agotamiento de la vía judicial previa (en nuestro caso, normalmente ante el propio Tribunal Constitucional), la última jurisdicción interna se vería desautorizada en Estrasburgo tras la correspondiente demanda individual (así lo advirtió el ex Presidente del TEDH: Discours du Président Dean Spielmann; Séminaire Tribunal constitutionnel, Madrid, 22 mai 2015; accesible en: http://www.echr.coe.int/ Documents/Speech_20150522_OV_Spielmann_Tribunal_constitutionnel_Madrid_ FRA.pdf, p. 7, último acceso el 20 de marzo de 2018.

Por último, por lo que se refiere a las «sentencias piloto» (técnica consagrada en primer lugar por la propia jurisprudencia del TEDH — caso Broniowski c. Polonia de 22 de junio de 2004 - y luego incorporada al CEDH tras la reforma operada por el Protocolo n. ${ }^{\circ} 14 \mathrm{CEDH}$, así como regulada en el art. 61 del Reglamento del TEDH), me parece que reflejan una de las «construcciones» más afortunadas del TEDH para impartir justicia en condiciones de celeridad y hacer frente a disfunciones estructurales y sistémicas, y, por ende, resultan acordes con el propio art. $6 \mathrm{CEDH}$ (para prevenir o evitar un contencioso repetitivo), a diferencia de otras construcciones y reformas de carácter procedimental que han ido en detrimento del mismo art. $6 \mathrm{CEDH}$ (el discutible filtro de in-admisibilidad ejercido por la figura del juez único con extremada brevedad y fórmulas inmotivadas).

En concreto, si con el Protocolo n. ${ }^{\circ} 14$ se habilitaba (en el nuevo art. 28 CEDH) a los Comités del TEDH al examinar una demanda individual para unánimemente «declararla admisible y dictar conjuntamente una sentencia sobre el fondo cuando la cuestión relativa a la interpretación o aplicación del Convenio o sus Protocolos que se encuentra en el origen del asunto haya sido objeto de una jurisprudencia bien sentada por el Tribunal» (sentencias piloto), el nuevo art. $27 \mathrm{CEDH}$ dotaba de competencia a los jueces únicos para inadmitir o archivar una demanda individual «cuando tal decisión pueda adoptarse sin tener que proceder a un examen complementario» (lo cual, en la praxis, se ha manifestado en la utilización de estereotipadas fórmulas de inadmisión en masa, como que la demanda estaría «manifiestamente mal fundada» o adolecería de «falta de apariencia de violación de derechos»).

\section{CARLOS RUIZ MIGUEL}

Por lo que hace a las «recomendaciones» que pueda hacer el TEDH, como he comentado antes, su tarea en su función judicial de interpretación del Derecho no es la 
elección y eventual justificación entre opciones «deseables», sino la delimitación de las opciones «admisibles» dentro del texto de la norma. En consecuencia, en su tarea de resolver casos creo que las «recomendaciones» que pueda hacer el TEDH (u otro Tribunal, Constitucional u ordinario) son algo improcedente pues implica que el tribunal se convierte en un actor político que manifiesta su preferencia por una opción en lugar de otra. Una vez que varias opciones resultan «admisibles» no es función del Tribunal declarar su preferencia por una de ellas.

La cuestión de las «recomendaciones» que pueda hacer un Tribunal está muy relacionada con la deficiente configuración de su competencia consultiva. Según como se configure la función consultiva del TEDH podría ser posible atribuirle la competencia de formular «recomendaciones», bien entendido que en los supuestos en que haya sido requerido para ello. Como es sabido, la actual configuración de la competencia consultiva no podía sino ser un fracaso. El artículo 47.2 del CEDH («opiniones no podrán referirse ni a las cuestiones que guarden relación con el contenido o la extensión de los derechos y libertades definidos en el Título I del Convenio y de sus Protocolos, ni sobre las demás cuestiones de las que el Tribunal o el Comité de Ministros pudieran conocer de resultas de la presentación de un recurso previsto por el Convenio») hace muy difícil imaginar supuestos en que se pueda formular una consulta al Tribunal. No es extraño que la competencia consultiva del TEDH no haya prosperado, a diferencia de lo que ocurre en el Tribunal Internacional de Justicia, en el Tribunal de Justicia de la Unión Europea o en la Corte Interamericana de Derechos Humanos.

Una vez en vigor, desde el 1 de agosto de 2018, el Protocolo n. ${ }^{\circ} 16$ es fácil prever que la competencia consultiva del TEDH adquirirá importancia. De acuerdo con el artículo 1.1 de este Protocolo, las más altas jurisdicciones de cada Estado parte podrán presentar demandas para la emisión de opiniones consultivas «sobre cuestiones de principio relativas a la interpretación o la aplicación de los derechos y libertades definidos en el Convenio y sus protocolos». Se trata de un procedimiento que de alguna manera se aproxima a una «cuestión de convencionalidad». Ahora bien, el hecho de que la consulta sólo pueda ser presentada por «las más altas jurisdicciones de cada Estado parte» hace que vaya a ser muy difícil que el TEDH emita «recomendaciones» al evacuar estas consultas. Muy diferente sería el caso si, como hubiera sido (en mi opinión) deseable, se hubiera atribuido TAMBIÉN a órganos políticos (como los gobiernos o los parlamentos nacionales) la competencia de solicitar opiniones consultivas. En tales casos, se podría entender que las «cuestiones de principio relativas a la interpretación o la aplicación» pueden incluir el solicitar al tribunal que emita su opinión acerca de qué opción, de entre las admisibles, pueda ser más «recomendable».

La cuestión de las «sentencias piloto» presenta otro tipo de problemas. Para situar en su debido contexto el debate sobre las «sentencias piloto» se deben hacer varias consideraciones previas. En primer lugar, desde el punto de vista formal, conviene recordar que las «sentencias piloto» son una anormalidad pues, si bien es cierto que están reguladas en el artículo 61 del Reglamento del TEDH («Rules of Court»), tras ser incorporadas al mismo el 21 de febrero de 2011, no es menos cierto que su existencia no está prevista en el texto del Convenio. En segundo lugar, las sentencias «piloto» se explican también por el hecho de que, a pesar del tenor literal del actual artículo $34 \mathrm{CEDH}$ (originariamente artículo 25 $\mathrm{CEDH}$ ), el Tribunal a veces ha admitido a trámite demandas en las que el reclamante no era propiamente hablando una «víctima», sino en las que impugnaba una norma general 
ante el temor de que pudiera ser singularizada para él. En tercer lugar, las «sentencias piloto» han sido una respuesta ante el fenómeno de una multiplicidad de demandantes que cuestionan normas singulares derivadas de una misma norma general.

El problema, por tanto, presenta dos vertientes. En primer lugar, formalmente resulta altamente llamativo que en ninguno de los Protocolos negociados y firmados por los Estados partes se halla planteado incorporar el procedimiento de las «sentencias piloto» al texto del Convenio. Parece claro que sería de todo punto necesario hacerlo para terminar con esta situación, a mi juicio, bastante irregular o, cuando menos, discutible. Pero además, en segundo lugar, materialmente conviene plantear el debate acerca de si, y en qué supuestos, los individuos pueden cuestionar una norma general ante el TEDH (los Estados pueden hacerlo desde la redacción original del TEDH —antiguo artículo 24, actual artículo $33 \mathrm{CEDH}-$ ). A este respecto, debemos ser conscientes de que el cuestionamiento de la «convencionalidad» de ciertas normas generales, en especial, las leyes, por parte de los individuos puede presentar serias disfunciones en un sistema como el español. De un lado, se presenta una disfunción por el hecho de que se pudiera atribuir al individuo legitimación para impugnar la «convencionalidad» de las leyes... allí donde se le niega legitimación para impugnar la «constitucionalidad» de las mismas (legitimación reservada a los jueces y a un número limitado de órganos o formaciones). De otro lado, el hecho de que el Protocolo número 16 (en vigor desde el 1 de agosto de 2018) permita a los más altos tribunales del Estado formular una «cuestión de convencionalidad» por vía consultiva no cierra el problema pues el dictamen no tiene fuerza ejecutiva y nada impediría, en teoría, que el tribunal nacional no lo asumiera y que, ante una eventual demanda contenciosa el TEDH pudiera llegar a cambiar o matizar su opinión por más que esto sea muy difícil. En todo caso, para que el procedimiento de la «cuestión de convencionalidad» por vía consultiva haga disminuir el uso del procedimiento de las «sentencias piloto» sería preciso que más Estados ratificaran el Protocolo número 16 que introduce la «cuestión de convencionalidad».

\section{ROSARIO TUR AUSINA}

Una de las cuestiones clásicas de la jurisdicción de Estrasburgo ha sido la de determinar la capacidad de alcance y fuerza ejecutiva de las resoluciones del Tribunal de Estrasburgo, en su intento por hacerlo compatible con la clásica idea de la soberanía estatal. Esto significa que, desde sus inicios, se tenía que modular singularmente la capacidad del TEDH para resolver las demandas que se le presentasen con los mecanismos idóneos para la reparación de las vulneraciones de derechos. Por ese motivo sus resoluciones no son ejecutivas, pero sí obligatorias; y en consecuencia no podían declarar la nulidad de los actos o resoluciones lesivas internas, tarea que se depositaba en los Estados. De algún modo, se pretendía forzar la colaboración de las Estados para crear obligaciones de resultado y no tanto de comportamiento (Lattanzi, Struttura dei rapporti internazionali e limiti dei procedimenti di garanzia istituiti con la Convenzione Europea dei Diritti dell'Uomo, 1988), pues con ello quedaba salvaguardada la soberanía estatal.

Sin embargo, desarrollos ulteriores evidenciaron, en efecto, una dinámica constitucional multinivel que matiza la mera superposición de niveles de gobierno y la hipotética perfecta delimitación entre obligaciones de comportamiento y de resultado. Se instaura, 
de esta forma, la técnica de las recomendaciones a los Estados, cuestionándose si son meras sugerencias o auténticas instrucciones o mandatos dirigidos a aquellos, lo que podría suponer un exceso de jurisdicción y una alteración de la naturaleza originaria de esta institución y, con ello, de la posición y relación entre los entes implicados. Pero lo que ha ocurrido, en realidad, es que parece haberse reformulado la idea de soberanía misma, pues se busca una soberanía, pero no encontramos un único — o varios- soberanos plenos; lo que ha hecho inoperativas las técnicas articuladoras de jerarquía y competencia entre sistemas institucionales y normativos, dotando al tiempo de mayor intensidad las formas cooperativas, de diálogo y de negociación.

Esto significa, en resumidas cuentas, que se convirtió en una constante en la jurisprudencia del Tribunal que, en las reparaciones individuales, este pusiera empeño en señalar los medios, formas o mecanismos recomendados para la mejor tutela de los derechos (Zimmerman y Steiner, de 13 de julio de 1983). Y lo ha hecho no solo vía obiter dictum (a modo de ejemplo, Gençel c. Turquía, de 23 de octubre de 2003; Ocalan c. Turquía, de 12 de mayo de 2015), sino indicando que sólo determinadas medidas de reparación son válidas y adecuadas (Assanidze c. Georgia, 8 de abril de 2004). Una apuesta decidida por convertir al Tribunal en auténtico órgano efectivo de tutela de los derechos del Convenio, asumiendo que las medidas de reparación se integran en la protección integral de los derechos, y que acompañan a la declaración de lesividad. Así, el Tribunal no solo juzga la lesión sino que hace ejecutar lo acordado con la medida efectivamente idónea. Cuestión diversa es quién ejecuta, cuándo y cómo; aspectos en los que se acciona, efectivamente, el espacio de soberanía de los Estados.

Pero es esta una técnica que ha de conjugarse, precisamente, con el margen de apreciación nacional de los Estados. En efecto, el Tribunal, con la colaboración de los Estados, ha de conseguir un difícil equilibrio entre 1) la construcción de un acervo constitucional común —no sólo teórico, sino real y concreto- 2) los aspectos ampliamente consensuados por los Estados en determinados momentos, y 3) los elementos en las que éstos se diferencian para mostrar sus propias singularidades. Cuestiones todas ellas que experimentan oscilaciones en el tiempo. Y así Estrasburgo se mueve en un maleable y constante diálogo — más o menos acertado - con los Estados, de tal forma que la técnica de las recomendaciones oscila entre lo que podríamos denominar un soft law jurisprudencial, indicando posibles medidas más o menos idóneas, o un pronunciamiento más decidido y firme por la única medida adecuada.

En nuestra opinión, es previsible que el Tribunal siga reforzando esta técnica y entienda, cada vez más, la necesidad de pronunciarse sobre las reparaciones, sin bajar la guardia cuando detecta que sus pronunciamientos no son sólidamente recepcionados en los Estados. Ahora bien, el que este diálogo funcione no dependerá solo del TEDH y de su parte de liderazgo — que en absoluto es imposición o mandato—, sino también de la capacidad de los Estados para asumir, integrar, conocer y modular constructivamente la jurisprudencia de Estrasburgo como parte de su propio sistema. Porque no se trata solo de europeizar el sistema español y acatar puntualmente las sentencias de Estrasburgo, sino de recepcionar y constitucionalizar dicha europeización. Ello exigirá por parte del Tribunal de Estrasburgo, una adecuada sensibilidad, conocimiento, y análisis profundo de los sistemas normativos e institucionales estatales. Pero también, del otro lado, una adecuada formación y un amable diálogo de las instancias nacionales - y de las fuerzas políticas y sociales - respecto a la jurisdicción supranacional. 
Pero es en la técnica de las recomendaciones generales, con la propuesta de genéricas reformas institucionales y normativas, donde se observa la naturaleza de auténtica jurisdicción constitucional —objetiva y abstracta- que posee el Tribunal, y que le otorga una especial función pedagógica. Una función que no debe verse, siempre que se haga en los adecuados términos argumentativos, sino como una especie de diálogo constructivo. Y es que quizá esta sea la característica diferenciadora clave de la distinción entre jurisdicciones ordinarias y constitucionales en nuestro sistema político. Distinción en la que es irrelevante, por razones más que obvias pues la respuesta positiva se impone, si la justicia ordinaria ha de aplicar/interpretar o no la Constitución y con ella los Tratados que se integran en el control de constitucionalidad/convencionalidad. La diferencia más significativa está sin embargo, y a nuestro juicio, en que la justicia ordinaria tiene como misión central — que no exclusiva - enjuiciar actos lesivos concretos y proceder a la reparación con medidas puntuales. No puede, por lo tanto, pretender cuestionar en sí mismo el sistema institucional y normativo ni dilucidar causas generales que conlleven el cuestionamiento de aquel en su conjunto —o de partes importantes del mismo- Aunque ello no elimina que en su importante función colaboradora con la jurisdicción constitucional/ convencional, puedan hacer uso del derecho jurisprudencial blando — vía obiter dictum-, o de la técnica de diálogo de las cuestiones prejudiciales o de constitucionalidad/convencionalidad. Por su parte, aunque el TC - y el TEDH con otro alcance- tampoco puede dilucidar causas generales, sí es una institución especialmente idónea para situarse en el plano de las reformas institucionales y normativas, valorándolas en su contexto y con deferencia hacia los órganos democráticamente electos. No obstante, también es cierto que la pasividad persistente de las instituciones democráticas y del TC podría llevar a pronunciamientos más agresivos de la justicia ordinaria, un riesgo que efectivamente aquellos no pueden correr. Por ello, en la capacidad para articular el sistema estará, precisamente, la madurez de una democracia.

Por su parte, no debe olvidarse que en esta dinámica de las recomendaciones el Tribunal Europeo ofrece —o debería ofrecer- una visión de conjunto a partir de su conocimiento de los sistemas constitucionales de 47 Estados, lo que constituye una valiosa aportación a la configuración de estándares comunes e, incluso, una vía para el recíproco conocimiento de los sistemas constitucionales de los Estados.

A pesar de la tendencia a caracterizar el recurso ante el TEDH como un amparo supranacional, acentuando su carácter subjetivo, es lo cierto que aquel es mucho más que una mera jurisdicción subjetiva de la libertad. De hecho, la naturaleza jurídica del Tribunal Europeo se reconduce en buena parte a una auténtica jurisdicción constitucional de la ley, es decir, para la depuración abstracta de los ordenamientos y políticas públicas estatales. Y es que no puede negarse su fuerte dimensión objetiva, en tanto pretende construir un acervo constitucional común supranacional europeo, lo que implica la búsqueda persistente de sistemas normativos e institucionales con unos mínimos estándares compartidos de libertad e igualdad. El propio Preámbulo del Convenio de Roma es suficientemente ilustrativo al respecto, con expresiones como la realización de una unión más estrecha entre sus miembros, o el mantenimiento de las libertades como bases de la justicia y la paz y cuyo mantenimiento reposa en un régimen político verdaderamente democrático y en una concepción y un respeto comunes de los derechos humanos.

Las denominadas sentencias piloto se inscriben en la misma lógica apuntada de las recomendaciones, pero en este caso para incidir en la necesidad de abordar posibles 
problemas estructurales estatales y ya no meramente coyunturales. Por ello mismo, estas sentencias aparecen tarde (Resolución del Comité de Ministros de 12 de mayo de 2004, y STEDH Broniowski c. Polonia, 22 de junio de 2004) y se afianzan lentamente, pero en un proceso que parece irreversible. En este caso, las recomendaciones a los Estados son, si se nos permite la palabra, especialmente invasivas, pues les indica la necesaria adopción de medidas generales que inciden en la propia articulación nacional de poderes y contrapoderes, corrigiendo problemas sistémicos, lo que supone un esfuerzo de integración y de compromiso global y complejo que afectará a su sistema normativo, institucional e incluso cultural o social. Más allá de que la sentencia piloto se activa cuando se han planteado — o podrían plantearse - una multiplicidad de demandas, y en tal sentido se genera por razones de eficacia cuantitativa, resulta más interesante y relevante la eficacia cualitativa: con dicha resolución no se trata tanto de evitar demandas — que también-, sino que el Tribunal hace una apuesta decidida por un cambio sustancial y sistémico que afecta al sistema político del Estado, a su núcleo constitucional y a la dinámica de poderes mismos, en una nueva relación de verticalidad Estado-Consejo de Europa no poco compleja. En tanto se trata de resolver el fondo del problema, las sentencias piloto son un soporte para los Estados, llevando a cabo una apuesta decidida por un pacto constitucional europeo más comprometido.

Por lo demás, la relevancia de estas sentencias (casos principales, frente al resto de casos recurrentes) se observa, precisamente, en que considerándose el problema a resolver como complejo o estructural, el mismo se somete a supervisión reforzada. Y ello en virtud de las dificultades que conlleva la ejecución de una sentencia piloto, pues no puede obviarse que las fuerzas políticas nacionales pueden no coincidir en la articulación concreta de las reformas, o los aspectos a reformar pueden mostrar una especial sensibilidad social y, en consecuencia, una dificultad adicional para la negociación. De nuevo aquí emerge la idea del fomento de la sensibilidad/aprendizaje multinivel europeo en las instancias internas, en una nueva muestra de esa lealtad constitucional que es necesaria.

No es posible negar, pues, las altas dosis de imaginación que ha desarrollado el Consejo de Europa y el Tribunal de Estrasburgo con estas prácticas, evidenciando el propósito común de construir un sistema verdaderamente integrado, por lo que no puede merecer más que una valoración positiva, aún con todas las dificultades.

6. Como es sabido, en la creación del espacio europeo de protección de derechos, el TEDH ha desarrollado una especial jurisprudencia protectora de la libertad de expresión. ¿Cómo valora tal jurisprudencia? ¿Quiere añadir algo sobre la ponderación que realiza el Tribunal de esa libertad fundamental con la probibición de los denominados delitos de odio?

\section{ENOCH ALBERTÍ ROVIRA}

El TEDH, en efecto, ha desarrollado una jurisprudencia muy extensa y variada sobre el art. $10 \mathrm{CEDH}$, que, para sintetizar, podemos denominar en general como libertad de expresión, aunque contiene elementos y aspectos diversos. Una constante en esta jurisprudencia (ya desde las emblemáticas Sentencias Handyside v. R, 1976 y Sunday Times v. RU, 1979), es la consideración de que este derecho, trascendiendo su 
dimensión estrictamente subjetiva e individual, desempeña un papel esencial en el funcionamiento del estado democrático. En función de esta posición central, el TEDH ha dispensado una amplia protección a la libertad de expresión (o al conjunto de libertades incluidas en el art. $10 \mathrm{CEDH}$ ), con especial énfasis en las comunicaciones que, fruto del ejercicio de estas libertades, se vinculan o contribuyen más directamente a la formación de una sociedad democrática. El TEDH aplica también aquí su doctrina del margen de apreciación nacional, especialmente para conceder a las autoridades nacionales libertad para valorar la concurrencia de circunstancias que justifican su limitación, en aplicación de los motivos que, según el propio Convenio, habilitan restricciones, con los problemas a los que ya se ha hecho referencia anteriormente. Pero este margen de apreciación es más reducido en este caso, debido al papel público esencial que desempeña la libertad de expresión, de modo que el escrutinio del TEDH desde el punto de vista de la adecuación, la necesidad y la proporcionalidad de las medidas restrictivas adoptadas por el Estado es más estricto (así, muy recientemente la STEDH Stern Taulats v. España, de 13 de marzo de 2018, que reduce el margen de apreciación nacional y afirma además, en general, el control del Tribunal no solo respecto de las actuaciones concretas de las autoridades nacionales, sino también de la ley de la que traen causa). Por tanto, el control por parte del TEDH sobre las actuaciones restrictivas de este derecho se acentúa, en extensión e intesidad, elevando el nivel de protección del derecho para asegurar que las medidas adoptadas por los Estados constituyan limitaciones necesarias y proporcionales en una sociedad democrática para garantizar ciertas finalidades legítimas, que el propio CEDH ampara (apartado 2 art. 10).

Yendo ya directamente a la cuestión del discurso del odio por la que se inquiere en esta pregunta, este celo especial en la protección de la libertad de expresión ha llevado también al TEDH a examinar de manera muy rigurosa la eventual aplicación del instituto del abuso de derecho en relación con la libertad de expresión, con ocasión precisamente de la alegación del discurso del odio para excluir determinadas expresiones de la cobertura de este derecho. Porque, en efecto, pueden adoptarse medidas restrictivas aplicando alguno de los motivos que justifican la limitación del derecho y que habilita el propio Convenio, medidas que serán objeto de control por parte del TEDH desde los principios de adecuación, necesidad y proporcionalidad; o bien puede pretenderse excluir directamente una determinada expresión o comunicación del ámbito de protección del derecho. Ello es lo que ocurre cuando se aplica el abuso de derecho: formalmente se está ejerciendo el derecho a la libre expresión, pero en realidad se incurre en un abuso de derecho, prohibido por el art. $17 \mathrm{CEDH}$. No pueden utilizarse derechos reconocidos en el CEDH para amparar actividades que tienden a la destrucción de estos mismos derechos. Los actos que expresan un discurso del odio tienden precisamente a negar e incluso destruir el sistema de derechos de la CEDH y los valores básicos en los que se fundamenta, y por ello no pueden merecer su protección, debiendo ser considerados un ejercicio abusivo del derecho a la libre expresión. Teniendo esta trascendencia fundamental, al quedar excluido de la protección que brinda el derecho a la libre expresión, es obvio que resulta imprescindible acotar lo más nítidamente posible el concepto y el ámbito del discurso del odio. Esta cuestión ha adquirido además un especial relieve en España en los últimos tiempos, con una actitud zigzagueante del TC (moviéndose entre posiciones muy permisivas, como la que manifiesta en la STC 235/2007, en la que considera que la negación, mera, del genocidio no puede ser objeto de persecución penal, y otras muy restrictivas 
- como la STC 177/2015, que considera legítima la condena penal por la quema de un retrato del Rey, por constituir una incitación al odio y a la violencia- que se enmarcan no obstante en una tendencia del Tribunal en general restrictiva de la libertad de expresión y de información que «alarma», en palabras textuales, a algún magistrado del propio Tribunal —VP de Xiol Ríos en la STC 177/2015-) y ha ocupado un lugar destacado en las acciones emprendidas por el ministerio fiscal con ocasión de la persecución penal alrededor del referéndum del 1 de octubre y del conflicto de Cataluña.

Para evitar que el argumento del discurso del odio, que una sociedad democrática tiene el deber de perseguir penalmente, se utilice para limitar ilegítimamente la libertad de expresión, que es fundamento de esta misma sociedad democrática, debe delimitarse con la mayor claridad posible su ámbito. Y para ello resulta útil acudir a la jurisprudencia del TEDH (SSTEDH Gündüz v. Turquía, de 4 de diciembre de 2003; Partido Popular demócrata-cristiano v. Moldavia-2, de 2 de febrero de 2010; Otegi Mondragón v. España, de 15 de marzo de 2011; Stern Taulats, citada, entre muchas otras) y también a algunos instrumentos comunitarios europeos, como la Decisión marco 2008/913 JAI, del Consejo, de 28 de noviembre de 2008, relativa a la lucha contra determinadas formas y manifestaciones de racismo y xenofobia mediante el derecho penal, que pueden arrojar luz en la cuestión. Creo que en este sentido merecen destacarse al menos dos elementos esenciales, que fueron bien entendidos en el VP de Xiol Ríos a la STC 177/2015: primero, los destinatarios del discurso del odio deben ser personas (y no instituciones), y, específicamente, grupos e individuos pertenecientes a los mismos, definidos por la raza, el color, la religión o el origen nacional o étnico (en la lista, abierta, de la Decisión marco 2008/913); y segundo, la expresión realizada, que debe ser pública, debe suponer una incitación a la violencia o a la negación de derechos de las personas o grupos concernidos. Naturalmente, no toda expresión que no incurra en estas dos circunstancias es automáticamente legítima. Podrá constituir, sin duda, un ejercicio ilegítimo de la libertad de expresión, pero no será un discurso de odio, y su legitimidad deberá medirse en todo caso mediante otros parámetros (p.ej., ponderación respecto de los derechos al honor o a la intimidad).

Estas dos condiciones no resuelven definitivamente la cuestión, pero sí ayudan a orientarla en una dirección, creo, adecuada. Y, desde luego, presentan también numerosos problemas que requieren un tratamiento que aquí no cabe. En un inventario que no es exhaustivo puede citarse, a modo de ejemplo, la posibilidad de ampliar los «factores de odio", dado que la lista de la Decisión marco es expresamente abierta, y que el TEDH ha considerado que pueden entrar en esta categoría otras formas basadas en la intolerancia (STEDH Gündüz c. Turquía, 2003, entre otras); o la caracterización de las conductas concretas que expresan el discurso del odio, cuestión en la que resulta muy difícil establecer criterios generales, dado que, además de su enorme variedad, su sentido depende en gran parte del contexto en el que se producen y las concretas circunstancias que las rodean. En todo caso, y dado que la libertad de expresión, como ha dicho repetidamente el TEDH, no sólo protege las manifestaciones complacientes o inocuas, sino también, y quizá especialmente, las que «chocan, inquietan u ofenden al Estado o a una fracción cualquiera de su población» (STEDH Handyside, ap. 49) o, en otras palabras, las que «hieren, ofenden o importunan» (STEDH Stern Taulats, ap. 31), es necesario proceder a una delimitación, con criterios restrictivos, del discurso del odio, pues incluir en él expresiones de protesta o de crítica supondría una restricción ilegitima de la libertad de expresión, y «probablemente 
perjudicaría al pluralismo, a la tolerancia y al espíritu de apertura sin los cuales no existe una sociedad democrática» (STEDH Stern Taulats, ap. 41).

\section{JUAN MARÍA BILBAO UBILLOS}

De forma globalmente positiva. En primer lugar, porque en la jurisprudencia del TEDH se ha insistido siempre en que la libertad de expresión tiene un significado que va más allá de la relevancia propia de un derecho individual: tiene una trascendencia o dimensión institucional en el marco de un sistema democrático. Sin comunicación pública libre, no hay sociedad libre, ni por tanto soberanía popular, no hay democracia en suma. La libertad de expresión es una piedra de toque para catalogar un régimen político, porque juega un papel decisivo en el control de los gobernantes (función de «perro guardián»). Sólo un ciudadano bien informado, no manipulado o adoctrinado, es capaz de formar libremente sus propias convicciones y participar de forma responsable en el debate público. Y en segundo lugar porque ha declarado repetidamente que en una sociedad abierta y pluralista, no sólo se protegen las informaciones o ideas acogidas favorablemente por la sociedad o consideradas como inofensivas o indiferentes, sino también (y sobre todo) las opiniones que incomodan, perturban o molestan a las autoridades o a algún sector de la población, que resultan impopulares, heterodoxas o "políticamente incorrectas», pero contribuyen al debate público. Este derecho adquiere pleno sentido cuando se ejerce para disentir de las convicciones dominantes. Y el Tribunal siempre ha tenido muy presente esta dimensión «contramayoritaria» de la libertad de expresión.

De ahí, por ejemplo, que se reconozca el carácter preferente de esta libertad en el ámbito del discurso político. En este ámbito, el Tribunal aplica un escrutinio muy estricto a la hora de juzgar las injerencias en su ejercicio. Lo sabemos muy bien, porque España fue condenada en 1992 en el caso Castells (un senador de HB condenado por injurias a la Corona por un artículo en el que denunciaba la complicidad de las autoridades españolas en la «guerra sucia» contra ETA) en una sentencia (que suele citarse como leading-case) que puso el acento en la necesidad de proteger especialmente la libertad de crítica de un político de la oposición y no acudir a la vía penal para sancionar posibles excesos si existen otras alternativas. Más recientemente, en el asunto Otegi Mondragón (2011), el Tribunal consideró que la condena por injurias al Rey impuesta al portavoz de la izquierda abertzale (que en una conferencia de prensa se había referido al Rey como «responsable de los torturadores que ampara la tortura y que impone su régimen monárquico a nuestro pueblo mediante la tortura y la violencia») vulneró el art. 10 del CEDH. El TEDH recuerda que el artículo 10.2 del Convenio apenas deja espacio para restricciones a la libertad de expresión en el ámbito del discurso y el debate político o de las cuestiones de interés general (en este caso, el cierre del diario Egunkaria y la detención de sus responsables algunos días antes, así como de la denuncia de malos tratos formulada por estos últimos). La libertad de expresión de un cargo electo, de un parlamentario, es especialmente valiosa, porque representa a sus electores, manifiesta sus preocupaciones y defiende sus intereses y se le puede permitir una determinada dosis de exageración, o incluso de provocación. En este caso, el demandante ofrecía una imagen muy negativa del Rey como institución y su discurso tenía una connotación hostil, pero no incitaba a la violencia ni se trataba de un discurso de odio. Además, los límites de la crítica 
admisible son más amplios cuando el afectado es un cargo público, que se expone inevitable y conscientemente a un control atento de sus hechos y gestos tanto por los periodistas como por el conjunto de los ciudadanos. Tiene que asumir que el grado de tolerancia es mayor que el exigible a un particular. En este sentido, el Tribunal reitera sus reservas respecto de la sobreprotección del honor o la reputación del Jefe del Estado mediante un tipo específico con una sanción más grave (art. 490.3 CP). A su juicio, esa mayor protección no se ajusta al espíritu del Convenio. Es un privilegio exorbitante, porque el hecho de que el Rey ocupe una posición de árbitro neutral y símbolo de la unidad del Estado no lo pone al abrigo de cualquier crítica en el ejercicio de sus funciones. La sentencia analiza, por último, la proporcionalidad de la sanción impuesta al demandante, que considera particularmente severa, aunque finalmente se suspendiera su ejecución. La condena resulta desproporcionada y produce inevitablemente un efecto disuasorio

En la jurisprudencia del TEDH, la intensa protección del discurso político y el debate público sobre cuestiones de interés general encuentra dos límites, ya apuntados en las sentencias que hemos comentado. La primera línea roja es la incitación a la violencia, su abierta justificación o el llamamiento a ejercer la violencia. Pocas dudas suscita esta excepción, que el Tribunal ha invocado como criterio determinante en todas sus sentencias sobre la disolución de los partidos kurdos en Turquía, por ejemplo. Más dificultades plantea la identificación del segundo de los límites: el discurso del odio (bate speech), un término con el que se designan las manifestaciones de odio, desprecio o intolerancia contra determinados grupos, que están motivadas por prejuicios ligados a religión, etnia, género, discapacidad u orientación sexual, entre otros factores. Se trata de expresiones que pueden resultar ofensivas porque reflejan una actitud de desprecio y de hostilidad hacia los integrantes de un determinado grupo. Es el discurso de los pirómanos que agitan y exacerban las tensiones culturales, raciales o religiosas y ponen en riesgo la convivencia entre grupos y comunidades. Para el Tribunal, este lenguaje hostil no llega a constituir incitación directa a la violencia, pero puede contribuir a crear un clima de tensión social, de crispación, que, debido al rencor acumulado, puede acabar quizá degenerando en violencia, en crímenes o delitos de odio, pero se trataría en todo caso de un efecto no inmediato, sino indirecto.

Por razones históricas, biográficas (la experiencia traumática del totalitarismo y del horror del holocausto ha marcado nuestra memoria colectiva) en Europa hemos aprendido la lección: más vale prevenir que lamentar. La tolerancia con los intolerantes puede conducir al suicidio (de ahí la concepción de la democracia como una democracia militante, beligerante con los enemigos de la libertad). No se confía en la capacidad de las democracias europeas para resistir la embestida de discursos tóxicos que niegan la igual dignidad básica de todos los seres humanos y crean un caldo de cultivo de hostilidad que puede desembocar en agresiones violentas. Para el Tribunal, se puede impedir su libre circulación, no hace falta esperar a que el discurso de odio constituya un peligro real e inminente para nuestras democracias, porque podría ser demasiado tarde.

Es este un punto en el que se observa una acusada divergencia entre el enfoque predominante en Europa, que es el que adopta el TEDH, y la protección a ultranza de la libertad de expresión en el ordenamiento norteamericano. En la regulación de esta libertad en las Constituciones europeas y en el propio art. 10 del Convenio se pone el foco en los límites y responsabilidades que entraña su ejercicio, mientras que la concepción norteamericana se puede definir como libertaria y viene marcada por la desconfianza hacia el 
Estado, por lo que se ve con recelo cualquier regulación estatal que, para fomentar valores como la igualdad o la dignidad, restrinja la libertad de expresión de los disidentes. En un contexto de recrudecimiento del racismo, del antisemitismo y la xenofobia en Europa, un fenómeno alarmante, se considera necesario adelantar las barreras de protección, reprimiendo penalmente las ideas basadas en el odio racial, en la convicción de que en muchos casos los crímenes de odio tienen su origen en la difusión de ideas o discursos de estigmatización, discriminación u odio hacia determinados colectivos sociales, que dañan la convivencia democrática y la integración de las minorías.

Con independencia del mayor o menor acierto en su aplicación, de la jurisprudencia del TEDH se desprende claramente que el lenguaje del odio es una forma de expresión que no merece ser protegida, porque no contribuye en modo alguno a un debate público fructífero. Su doctrina se resume en la idea de que «la tolerancia y el respeto a la igual dignidad de todos los seres humanos constituyen el fundamento de una sociedad democrática y pluralista, por lo que en principio se puede juzgar necesario sancionar, e incluso prevenir, todas las formas de expresión que propaguen, inciten a, promuevan o justifiquen el odio fundado en la intolerancia... siempre que las condiciones, restricciones o sanciones que se impongan sean proporcionadas al legítimo objetivo perseguido (Erbakan c. Turquía, 2006).

Es más, el Tribunal de Estrasburgo, al igual que en las decisiones relativas a la negación de hechos históricos «bien establecidos» como el Holocausto, ha acudido en ocasiones al art. 17 del Convenio (la cláusula del «abuso de derecho»), para justificar ese rechazo, con el argumento de que la libertad de expresión no puede ejercerse para actividades contrarias al texto y al espíritu del Convenio, que, si fuesen admitidas, contribuirían a la destrucción de los derechos y libertades previstos por dicho Convenio. Con esta cláusula se quiere impedir que los enemigos de la democracia se sirvan de los derechos reconocidos en el Convenio como caballos de Troya para desestabilizar el sistema democrático y los valores que lo conforman. En estos casos, el Tribunal declara directamente la inadmisibilidad de la demanda, sin entrar a analizar el fondo del asunto por tratarse de mensajes frontalmente opuestos a los valores esenciales del Convenio. Fue en el asunto Glimmerveen y Hagenbeek c. Holanda (1979), en el que por primera vez_la Comisión recurrió a este arma de grueso calibre para impedir que al amparo del artículo 10 pudieran propagarse ideas o mensajes racistas. Los demandantes habían sido condenados por estar en posesión de octavillas que incitaban a la discriminación racial y se les había impedido presentarse como candidatos a las elecciones municipales de un partido que defendía una concepción del mundo basada en Estados étnicamente homogéneos.

En el caso Norwood vs. Reino Unido (2004), el demandante, un militante del Partido Nacional británico (BNP) que tras el ataque del 11-S contra las torres gemelas de Nueva York había colocado en su ventana un cartel que mostraba la imagen de dos torres gemelas ardiendo, acompañada de la frase «Fuera el Islam-Protejamos al pueblo británico», había sido condenado a una multa en aplicación dela Ley de Orden Público de 1986. El TEDH resolvió el caso aplicando la cláusula del art. 17: "palabras e imágenes como las contenidas en el póster constituyen la expresión pública de un ataque contra todos los musulmanes del Reino Unido. Un ataque tan vehemente, con carácter general, contra un grupo religioso, que establece un vínculo entre el grupo en su conjunto y un grave acto terrorista, es contrario a los valores proclamados y garantizados por el Convenio, a saber, la tolerancia, la paz social y la no discriminación», por lo que no goza de la protección del art. $10 \mathrm{CEDH}$. 
En otras ocasiones, sin embargo, y esta es la tónica dominante en la actualidad, el TEDH aplica el test de proporcionalidad y entra a valorar las circunstancias que rodean el caso: el contenido y la forma de la expresión, la intención del autor de la misma, el contexto y el previsible impacto del mensaje en la sociedad, su contribución al debate público, así como la gravedad de la sanción. Así resolvió, por ejemplo, el polémico asunto Jersild c. Dinamarca (1994), que trae causa de la emisión de un programa televisivo sobre bandas juveniles neo-nazis en el que miembros de uno estos grupos de adolescentes vierten comentarios racistas y xenófobos. La sentencia deja claro que los tres jóvenes condenados por sus declaraciones insultantes y amenazantes no podían beneficiarse de la protección del art. 10, que no ampara el discurso racista.

En el caso Soulas y otros c. Francia (2008), los demandantes fueron condenados a una multa como autores o cómplices de un delito de provocación al odio o la violencia por la publicación de una obra («La colonización de Europa. Discurso verdadero sobre la inmigración y el islam») en la que se defendía la incompatibilidad de la civilización europea con la civilización islámica. El TEDH valora, entre otras cosas, que los tribunales franceses habían subrayado que el libro trataba de provocar en los lectores un sentimiento de rechazo y antagonismo en contra de las comunidades que se califican de principal enemigo. Teniendo en cuenta el margen de apreciación de las autoridades francesas, el Tribunal estima que la injerencia en el derecho de los demandantes a la libertad de expresión era necesaria en una sociedad democrática.

Una de las sentencias más emblemáticas en esta materia es la dictada en 2009 en el asunto Féret c. Bélgica. El demandante, diputado y presidente del partido político Frente Nacional, había sido condenado a trabajos de interés para la comunidad y a una pena de ineligibilidad de 10 años, por incitación pública a la discriminación o al odio racial, por haber distribuido determinadas octavillas en el curso de la campaña electoral de su partido. Estos panfletos exhortaban a oponerse a la islamización de Bélgica, a interrumpir la política de seudo-integración, a dar prioridad en el empleo a los belgas, y a repatriar a los desempleados extraeuropeos. También se asociaba a los musulmanes con el terrorismo. Pues bien, aunque la sentencia comienza recordando que la libertad de expresión del demandante merece la máxima protección al tratarse de un discurso político ejercido en el marco de una campaña electoral, el Tribunal advierte que su discurso suscitaba inevitablemente sentimientos de desprecio, de rechazo, incluso de odio hacia los extranjeros. Ese mensaje difundido en el contexto electoral tenía aún mayor resonancia y constituía una incitación al odio racial. En consecuencia, la condena del demandante estaba justificada con el fin de proteger el orden público y los derechos de los demás (de la comunidad inmigrante, en este caso).

En esta sentencia se aprecia con mucha nitidez la postura del Tribunal: en los supuestos en los que las expresiones hostiles se dirigen contra grupos vulnerables que sufren discriminación, el criterio de la incitación a la acción es irrelevante. Se rechaza por tanto la doctrina norteamericana del clear and present danger: esas expresiones son en sí mismas inaceptables, aunque no se incite a la violencia o al delito, porque son discriminatorias y contrarias a la dignidad humana. Es una decisión polémica, porque estamos en la brumosa frontera entre el discurso que atiza el odio al inmigrante y las manifestaciones xenófobas que tendrían cabida en el debate político. ¿Serían punibles los mensajes xenófobos de formaciones como la Liga en Italia, el Frente Nacional en Francia o Alternativa para Alemania? En España, unas declaraciones similares del candidato a la alcaldía de 
Badalona, Garcia Albiol, no fueron consideradas delictivas (SAP Barcelona de 22 julio 2014). Una decisión que se sustenta en los mismos argumentos que esgrimen los tres jueces que formulan la opinión disidente a la sentencia dictada en el caso Féret. A su juicio, el discurso político no se puede reprimir penalmente. Son conscientes de que el impacto a largo plazo de la propaganda xenófoba constituye un grave problema para las sociedades democráticas. Pero una noción del discurso del odio que vaya más allá de la incitación directa a la violencia o la intolerancia es demasiado amplia para ser compatible con una protección firme del discurso político. El peligro potencial de una serie de consignas políticas aisladas no justifica una respuesta penal tan desproporcionada. La cuestión es muy delicada y a uno le asaltan muchas dudas, pero tiendo a pensar que no es una buena idea acudir a los tribunales para expulsar a golpe de sentencia las propuestas políticas que se inscriben en el marco de un debate de interés general sobre los problemas derivados de la integración de los inmigrantes. Me parece más eficaz combatirlas con argumentos que censurarlas o condenarlas en sede judicial.

Mención aparte merece la reciente STEDH de 13 de marzo de 2018 en el asunto Stern Taulats y Roura Capellera c. España, que aprecia la existencia de una vulneración de la libertad de expresión de los dos demandantes, condenados por quemar una fotografía de los Reyes de España en el curso de una manifestación pública. En contra del criterio sostenido por nuestro Tribunal Constitucional, que consideró que eran culpables de incitación al odio y a la violencia contra el Rey y la Monarquía, el TEDH declara que el acto cometido por los demandantes formaba parte de una crítica política, no personal, de la monarquía como institución, y del Reino de España como nación. Se enmarcaba dentro de una campaña de actos de provocación programados con el fin de atraer la atención de los medios. El Tribunal considera que los demandantes utilizaron la imagen del Rey como símbolo de su condición de Jefe del Estado y decidieron prender fuego a la fotografía como expresión de su rechazo a la institución. La intención de los demandantes no era incitar a nadie a cometer actos de violencia contra el Rey. En conclusión la pena de prisión impuesta a los demandantes no es proporcionada al objetivo perseguido ni necesaria en una sociedad democrática. Esta sentencia, cuyo fallo comparto plenamente, es muy importante, porque deja muy claro cuál es el concepto canónico de «discurso de odio» que el TEDH ha ido perfilando, frente a las interpretaciones que vienen a banalizar o desvirtuar su genuino significado, que no es otro que el de proteger a grupos vulnerables, no a las autoridades o instituciones.

Entre estos grupos, por cierto, hay que incluir a los homosexuales. En relación con la homofobia, el odio motivado por la orientación sexual, cabe destacar la Sentencia dictada en el caso Vejdeland y otros c. Suecia (2012). Los demandantes habían sido condenados por distribuir en un instituto de enseñanza secundaria panfletos en los que se afirmaba que la homosexualidad era una inclinación sexual desviada, que destruía los fundamentos morales de la sociedad sueca, y que era una las principales causas de contagio del VIH y de otras enfermedades de transmisión sexual. El Tribunal sostuvo que, si bien los pasquines no incitaban directamente a cometer actos de violencia contra los homosexuales, contenían graves y perjudiciales acusaciones. Cualquier ataque contra un grupo específico de la sociedad, ya sea por medio de insultos o de declaraciones que busquen ridiculizarlo o difamarlo, es suficiente para que las autoridades privilegien el combate contra los discursos racistas frente a la libertad de expresión, cuando se ejerce de forma irresponsable. Y declaró además que la discriminación basada en la orientación sexual es de igual gravedad que aquella que se basa en la raza, el origen o el color. 


\section{VÍCTOR FERRERES COMELLA}

La doctrina del TEDH en materia de libertad de expresión ilustra dos importantes características generales de su jurisprudencia. En primer lugar, el Tribunal no circunscribe su radio de acción a los casos más claros de violación de la libertad de expresión, sino que entra también a resolver asuntos altamente polémicos, como sucede, por ejemplo, con la prohibición del discurso del odio (hate speech). En segundo lugar, se trata de una jurisprudencia muy casuística. El TEDH, en efecto, sopesa un amplio conjunto de factores para determinar si, en las circunstancias concretas del litigio específico, la restricción que ha sufrido la libertad de expresión está o no justificada. Es extraordinariamente difícil «resumir» la jurisprudencia del TEDH a través de una serie más o menos reducida de reglas categóricas. Un ejemplo paradigmático del casuismo del TEDH lo encontramos en el asunto Perinçek contra Suiza (sentencia de 15 de octubre de 2015), a propósito de la negación del genocidio armenio. El Tribunal trata de distinguir entre un discurso pronunciado en Francia, por ejemplo, en el que se niega el Holocausto judío, y un discurso pronunciado en Suiza negando el genocidio armenio. Mientras que la libertad de expresión prevalece en este segundo caso, no lo hace en el primero. El Tribunal intenta justificar el contraste entre los dos supuestos a partir de múltiples factores (entre los que se encuentran el grado de distancia geográfica y el grado de distancia histórica). A mi juicio, y tal como argumentan los jueces que suscriben opiniones disidentes en el mencionado asunto Perinçek, la jurisprudencia del Tribunal no es coherente en esta materia. Quizás sería mejor que el Tribunal redujera el grado de casuismo con el que aborda los problemas de libertad de expresión, y elaborara reglas más generales, «resistentes» a la variedad de circunstancias de los distintos casos.

\section{JAVIER GARCÍA ROCA}

1. Valoro también favorablemente las aportaciones de la jurisprudencia europea al derecho a la libertad de expresión y otras libertades de la comunicación en una sociedad democrática, tal y como Rafael Bustos ha demostrado con más detalle en nuestro comentario al Convenio Europeo la Europa de los derechos.

Es una jurisprudencia extensa y en su día novedosa que ha tenido un serio influjo en los Estados, en particular al sentarse las bases de la jurisprudencia constitucional española, y que ha ayudado a crear unas sociedades más tolerantes y abiertas. Por más que pueda albergar claro está carencias y problemas. Dar noticia de la misma, siquiera sucinta, y de sus limitaciones y críticas requeriría un espacio muy amplio que resultaría inadecuado en esta encuesta. Me limitaré a dar algunas pinceladas impresionistas.

El artículo $10 \mathrm{CEDH}$ reconoce la libertad de expresión en una triple dimensión, que el propio precepto concreta, libertad de opinión, libertad de transmitir información, y derecho a recibir información, sin perjuicio de que es manifiesto que existen bastantes otras facetas y derechos propios de la libre comunicación y no mencionados expresamente allí.

Recordaré la progresiva y trascendental liberalización de la radiodifusión en los años noventa, rompiendo el viejo monopolio del servicio público estatal para permitir el acceso a manos privas, y el reconocimiento del derecho a la creación de medios de comunicación por cualquier soporte que ha impulsado el TEDH. Subrayaré la importante sentencia 
Invormationsverein Lentia contra Austria, de 24 de noviembre de 1993, que tanto influjo tuvo en el cambio de la jurisprudencia de nuestro Tribunal Constitucional para reconocer este derecho en la sentencia sobre la ley de la televisión privada y aún más en otras en esa época. Unas cuestiones que investigué durante un tiempo.

El Tribunal Europeo no distingue normalmente entre las libertades de expresión e información como hace el Tribunal Constitucional español. El basamento de toda la construcción es el papel esencial de la libertad de expresión en un sociedad democrática, siguiendo un entendimiento institucional y objetivo del derecho aunque el TEDH no lo diga así. Son esenciales los muy conocidos casos Handyside contra el Reino Unido, de 7 de diciembre de 1976, Sunday Times contra el Reino Unido, de 27 de abril de 1979, y Lingens contra Austria, de 6 de julio de 1986. Sin libertad de expresión no existe una opinión pública libre — se dice- - y esta dimensión objetiva concede un lugar central a esa libertad en el sistema de los derechos civiles y políticos. No se trata sólo de las libertades profesionales de los periodistas sino de la libertad de comunicación de todos.

La primera manifestación de la libertad de expresión protegida fue la libertad de prensa (freedom of press, journalist freedom) en cualquier asunto de interés general que despierte la preocupación de los ciudadanos. Está especialmente protegida, para evitar que se impida a la prensa cumplir su papel como perro guardián (public watchdog) de la democracia, informando al público de lo que ocurre. Una faceta ya sostenida por la Corte Suprema de Estados Unidos, pero que el TEDH ha reiterado mucho en su jurisprudencia en cientos de casos con paciencia hasta que la idea ha ido calando y se ha consolidado, por más que no deje de haber frecuentes violaciones que las sentencias declaran.

El grado de conexión con el interés general determina la intensidad de la protección de la libertad de opinión y expresión. De suerte que las fuertes críticas políticas a los gobiernos y a las instituciones públicas deben ser toleradas. La Corona entre ellas según el caso Otegui Mondragón contra España, de 15 de marzo de 2011, confirmada en otra posterior, que si bien no declaran contrario al Convenio el delito de injurias al Jefe del Estado, hacen prácticamente imposible su aplicación, una cuestión sobre la cual el legislador debería hacer algo. Una excepción a la regla parece ser el Poder Judicial y sus autoridades donde tiende a ponderarse y protegerse la necesaria confianza de los justiciables en los procesos frente a críticas periodísticas especialmente duras, pese a que en ocasiones se admiten, reclamando la carga de una reforzada comprobación de los hechos.

En general, el Tribunal Europeo es muy reacio a admitir la imposición de penas privativas de libertad como sanción del ejercicio de la libertad de expresión al considerar la privación de libertad por estas conductas una medida desproporcionada y no necesaria en una sociedad democrática.

Deben soportar también este estándar convencional, la tolerancia a la crítica, las personas públicas en general, y en especial, los políticos, incluido el uso de términos abusivos o constitutivos de insultos, que puede merecer la calificación de afirmaciones tolerables, si sirven al debate y a crear opinión pública libre, resultando embebidos en las noticias e informaciones que se ofrecen. Es ilustrativo Lopes Gomes da Silva contra Portugal, de 28 de septiembre de 2000, un candidato a la alcaldía de Lisboa al que se calificó en un medio de idiota, nazi o grotesco personaje, calificativos que se aceptaron para permitir dar publicidad a sus ideas racistas. Un grado de abuso es inherente al uso. El estándar es sensato si se contempla desde la perspectiva institucional que la jurisprudencia asume y no es fácil decantar límites. 
En efecto, el Tribunal Europeo ha protegido especialmente la libertad de comunicación en los debate públicos y, en especial, en el ámbito de la discusión y la crítica política y de la democracia representativa (political speech), donde ha sido muy exigente a la hora de tolerar límites. La libertad se combate con más libertad y suele decirse que una sociedad abierta debe admitir las críticas sin prohibirlas, aunque se trate de ideas chocantes y molestas y hasta irritantes para la inmensa mayoría de una comunidad nacional (vid Lebideux et Isorni contra Francia, de 23 de septiembre de 1998 sobre la defensa de la República de Vichy). En este contexto, también pueden tolerarse provocaciones o exageraciones.

Se han interpretado, por tanto, muy restrictivamente las interferencias en la libertad de opinión de los representantes políticos y esta comprensión tiene pleno sentido democrático. También de los Abogados que se encuentran ejerciendo el derecho a la defensa de sus clientes para garantizar el derecho al proceso debido. Mientras, en cambio, el nivel de protección que merece la libertad de expresión en la publicidad o en el comercio es lógicamente menor, pues no existe un acusado interés general que tutelar. Estas ponderaciones me parecen sensatas de nuevo.

Otras manifestaciones y derechos protegidas en la jurisprudencia, sin ánimo de exhaustividad, son el secreto profesional de los periodistas, el derecho de acceso a los medios públicos en ciertas condiciones, o el derecho a la investigación de los hechos que deben ser objeto de información en relación con la actuación de la policía o de la hacienda pública en personas públicas y otros extremos.

Más complejo y confusa —inevitablemente- es la jurisprudencia respecto de los límites a la libertad de expresión, pues tienden a ser ponderaciones de derechos e intereses nada seguras. El apartado 2. ${ }^{\circ}$ del artículo $10 \mathrm{CEDH}$, como otros preceptos del Convenio, reconoce expresamente la validez de ciertos límites, siempre y cuando resulten medidas necesarias en una sociedad democrática, estén previstos en las leyes, y se funden en fines a priori legítimos como pueden ser la seguridad nacional, la integridad territorial, la prevención del delito, la protección de la salud o de la moral, y otros allí previstos, pero no es un enunciado tasado sino ejemplificativo. La verdad es que el TEDH, muy acertadamente y siguiendo el mismo enfoque institucional y democrático que he descrito, ha sido muy escrupuloso a la hora de aceptar límites a la libertad de expresión por más que igualmente reconozca un margen de apreciación nacional. La prohibición del discurso del odio (hate speech), cuestión a la que luego me referiré, es uno de los pocos límites razonables a la libertad de expresión que se han decantado.

Catalá y Bas y Bustos han sistematizado la jurisprudencia sobre los límites derivados de los intereses generales que el apartado $2 .^{\circ}$ del artículo 10 enuncia y concluyen que el TEDH no es excesivamente receptivo a admitir injerencias derivadas de lo que podemos llamar «seguridad pública» (seguridad nacional, orden público, prevención delito, seguridad nacional, integridad territorial), si no resulta evidente el carácter sensible de la información que merece ser protegida de la divulgación o se pone seriamente en riesgo el sistema democrático. Es patente que el orden público fue un límite creciente de la libertad de información en España durante la dictadura del General Franco y que otro tanto ocurre en diversos países autoritarios, recuérdese la consideración como terroristas de buena parte del nacionalismo y separatismo kurdo en Turquía, dificultándose incluso el uso del kurdo en las campañas electorales. De manera que un entendimiento restrictivo de esta cláusula tan expansiva resulta lógico para restablecer el equilibrio. 
Por el contrario, las cuestiones morales o éticas, — concluyen su análisis estos autorescon mayor razón si están ligas a sentimientos religiosos, suelen permitir la introducción de un cierto margen de apreciación nacional. Pero no siempre. Los Casos del Partido de la Prosperidad y Müslum Günduz ambos contra Turquía, respectivamente, de 31 de julio de 2001 y 4 de diciembre de 2003, vinieron a reconocer que la Sharia, o cuando menos muchos de sus entendimientos, eran difícilmente compatibles con los valores democráticos; si bien es distinto incitar a la violencia contra los infieles por motivos religiosos que defender la Sharia sin llamar a la violencia. Son casos, por otra parte ligados a la defensa de la democracia como límite específico y muy resbaladizo, según he evidenciado en mi comentario a este caso del Refah Partisi. A veces es complejo saber y más de forma preventiva quién es un enemigo de la democracia.

Quizás donde la jurisprudencia es menos consistente y requeriría algunos matices y mejoras - por otra parte nada sencillas de hacer- es respecto de la colisión con los derecho al honor o reputación, la vida privada y la propia imagen como límites imprecisos a la libertad de expresión; pero otro tanto semejante ocurre con las jurisprudencias nacionales. El artículo 10 del Convenio no menciona el honor como derecho sino que alude a la «protección de la reputación» al hablar de los límites, parece referirse a la consideración objetiva que los demás tienen de una persona o «reputación ajena». El TEDH ha distinguido, como la Supreme Court de EEUU, entre personas públicas y privadas, y lo mismo ha hecho nuestro Tribunal Constitucional en este diálogo judicial; también se ha usado la pauta de la propia conducta y la esfera íntima o reservada delimitada por su titular. Pero ya sabemos que las ponderaciones con estos estándares en los supuestos de conflicto no son nada seguras. Con mayor razón, si pueden admitirse exageraciones y debe al tiempo preservarse la crítica política y el derecho a recibir información. Con el derecho a la intimidad o a la vida privada y familiar y la captación de imágenes de personajes públicos y sus familias en lugares públicos ha habido bastantes problemas a la hora de decantar algunos razonables límites en aspectos de su vida no conectados con sus funciones públicas; son conocidas las sentencias respecto de Carolina de Mónaco (Von Hannover contra Alemania, de 24 de junio de 2004) y las controversias acaecidas entre tribunales.

2. El discurso del odio (hate speech) es uno de los pocos límites internos y estructurales a la libertad de expresión en una sociedad abierta. Esto es claro y lo comparto plenamente. Pero la expresión puede que no sea tan afortunada, pues no es nada precisa a la hora de introducir un límite. No es nítida la diferencia entre un discurso del odio, que no puede estar protegido por la libertad de expresión en una sociedad decente y queda fuera de su ámbito normativo, y los discursos provocadores, ofensivos inoportunos e impopulares que por el contrario sí lo están ${ }^{7}$.

En un mercado de las ideas donde el pluralismo es un valor constitucional y donde no existe una idea de democracia militante, los discursos deben combatirse normalmente con otras ideas y no mediante un Derecho represivo. Así el Tribunal Constitucional (STC 235/2007) declaró inconstitucional el tipo penal que castigaba la negación del genocidio, pero el legislador penal ha vuelto a introducirlo en 2015, si bien el asunto tiene que ver con un injustificable racismo. Al cabo, una Decisión Marco del Consejo de la UE de 2008 incidía en la lucha contra determinadas formas de racismo y xenofobia mediante el

7 Cfr L. Alonso y V. VÁzQuez (dirs.): Sobre la libertad de expresión y el discurso del odio. Textos críticos. Prólogo de A. Cortina, Athenaica, Sevilla, 2017. 
Derecho Penal. El racismo es una manifestación cierta e intolerable del discurso del odio entre comunidades, y así ocurre también con la incitación al terrorismo. De hecho, el TEDH tiene a considerar incluidas en el concepto las incitaciones a la violencia y las expresiones de odio racional, antisemita o islamofóbicas o contra los extranjeros, y el negacionismo como forma de difamación racial. Pero hay otros terrenos menos nítidos que podrían considerarse por algunos incluidos dentro del discurso del odio y no deberían ser criminalizados, aunque puedan estar excluidos de la libertad de expresión.

Mientras el paradigma estadounidense se caracteriza por la tolerancia absoluta al amparo de la Primera Enmienda a la Constitución, un segundo paradigma europeo ha sentado límites respecto de afirmaciones que inciten a la violencia o la discriminación. Puede leerse Otto Preminger-Institut contra Austria, de 20 de septiembre de 1994, referido a un secuestro judicial de una película que incurría en blasfemia u ofensas religiosas cuya convencionalidad esta sentencia del TEDH aceptó con varios votos disidentes.

No obstante, Juan Antonio Carrillo Donaire advierte que a raíz de casos como el del seminario francés Charlie Hebdo en 2015, o la publicación de viñetas de Mahoma en un diario danés en 2005, y la creciente presencia de serias amenazas del terrorismo islámico se abre un debate europeo sobre la conveniencia de penalizar la difamación religiosa ${ }^{8}$. Un segundo problema es pues la necesidad o conveniencia de la represión penal de estas prácticas ligadas a un concepto inseguro.

No obstante, no me resisto a traer a colación que la blasfemia está en el mismo origen de la libertad de expresión y la tolerancia desde el provocador escrito publicado en 1755 por Voltaire sobre la doncella o la virgen de Orleans con afán de burlarse de uno de los mitos nacionales franceses más arraigados en su época. Vamos a prohibir o criminalizar a Voltaire o los cuentos... Me parece esencial una tolerancia intercultural.

Aunque no faltan pensadores como Karl Popper que creen que un exceso de tolerancia conduce necesariamente a la supresión de la tolerancia. Una posición que le lleva a declarar como enemigos de una sociedad abierta a todos los pensadores que tacha de idealistas y cuyo pensamiento no comparte. No me parece cabal combatir excesos con más excesos. El buen Derecho Constitucional demanda equilibrio. El problema del discurso del odio es en última instancia un debate sobre la tolerancia y admito abrigar aquí una idea muy liberal que me lleva a que no me guste mucho prohibir. Hay que pensárselo mucho antes prohibir y mucho más antes de introducir penas privativas de libertad.

Pero la verdad es que ha habido una tendencia a penalizar los delitos del odio en Europa. La reforma del Código Penal de 2015 en sus artículos 510 y 520, principalmente, sigue esta estela. Pero sensatas recomendaciones del Consejo de Europa sugieren otras vías represoras de menor intensidad. Advierto un salto en el razonamiento con la tutela penal de cualesquiera manifestaciones relacionadas con el discurso del odio sin mayores limitaciones, tipificando numerosos contenidos y conductas. Tengo además serias dudas de que los jueces penales, por oficio prudentes en su minimalismo, apliquen tipos tan largos y amplios como el farragoso artículo 510 del Código Penal que ocupa varias páginas y castiguen a los acusado con penas privativas de libertad. Quizás deberíamos comenzar por saber si el tipo se aplica en la realidad, porque de no ser así, quizás deberíamos dudar de la validez del precepto y revisarlo para hacerlo más chiquito.

8 Idem, p. 23. 
En la presentación del libro en la Complutense sobre el discurso del odio que acabo de citar, una filósofa con la autoridad de Adela Cortina — quien prologaba el libroexpuso con brillantez cuan inaceptable moralmente era este discurso, para luego defender su criminalización, alegando que «había que mandar un mensaje claro a la sociedad». Como yo presidía el acto me sentí obligado a añadir con cariño que quizás fuera así, y fuera menester una actuación contundente de los poderes públicos y represiva, pero que convenía castigar penalmente sólo las conductas más graves e indubitadas, y no las mínimas. Argumentando lo inadecuado del amplísimo tipo del artículo 510 del Código Penal, que no parece contener límites en cualquier manifestación de «odio, hostilidad, discriminación» por cualquier motivo. Me preguntaba si íbamos a encarcelar a un Obispo de la Iglesia Católica que había hecho entonces unas afirmaciones muy ignorantes, inadecuadas y ofensivas sobre la homosexualidad, amparándose en supuestas ideas religiosas. Ciertos ataques vehementes y absurdos no pueden ser tolerados pero no deben ser criminalizados con penas privativas de libertad.

\section{LUIS JIMENA QUESADA}

La jurisprudencia del TEDH sobre la libertad de expresión constituye, seguramente, uno de los reflejos más paradigmáticos de los tres pilares del Consejo de Europa (Estado de Derecho, Democracia y Derechos Humanos). Ya la STEDH Handyside c. Reino de 7 de diciembre de 1976 incluyó un pasaje en el que se condensaba su trascendencia, contenido y límites, sosteniendo que tal libertad se erige en «uno de los principales fundamentos de una sociedad democrática y una de las condiciones más importantes para su progreso y el desarrollo individual. Sin perjuicio del apartado 2 del artículo 10, dicha libertad incluye no sólo las «informaciones» o «ideas» acogidas favorablemente o consideradas como inofensivas o indiferentes, pero también las que golpean, chocan o inquietan al Estado o a una parte de la población. Así lo quieren el pluralismo, la tolerancia y el espíritu de apertura sin los cuales no hay «sociedad democrática». De ellos se desprende, en particular, que toda «formalidad», «condición», «restricción» o «sanción» impuesta en la materia debe ser proporcionada al fin legítimo perseguido» (párrafo 49).

Resultaría muy prolijo efectuar un balance de los tipos de mensajes comprendidos en el ámbito material de la libertad de expresión (políticos, religiosos, artísticos, comerciales - en este caso, no como contenido principal, sino a título secundario-) y el juego de las restricciones en estas décadas de jurisprudencia del TEDH. Por añadidura, un balance general, con respecto al conjunto de países del Consejo de Europa, se revelaría enormemente complejo, precisamente por el modo en que el TEDH ha hecho operativo el margen de apreciación nacional y la diversa entrada en escena (en el tiempo y en el espacio) de las eventuales limitaciones previstas en el apartado 2 del art. $10 \mathrm{CEDH}$. Con tales presupuestos y matices, el balance general sólo puede ser positivo. Por otra parte, el balance específico con relación a España (en el que me centraré a continuación), tampoco puede ser negativo, si bien es necesario introducir algunos elementos críticos para que la jurisprudencia del TEDH (sin duda, objeto de controversia política, social y mediática) sea correctamente entendida sin caer en fácil tergiversación e hipócrita corrección política.

Particularmente, en lo que nos concierne, a diferencia del prisma restrictivo en el terreno sindical (STEDH Palomo Sánchez y otros c. España de 12 de septiembre de 2011), 
se ha conferido una gran amplitud al ejercicio de la libertad de expresión por la abogacía en el foro (STEDH Rodríguez Ravelo c. España de 12 de enero de 2016), o por la profesión periodística en el escenario de la discusión política (STEDH Jiménez Losantos c. España de 14 de junio de 2016). Como contrapunto, como la ponderación («balancing») del juego de los apartados 1 y 2 del art. $10 \mathrm{CEDH}$ es susceptible de delicados equilibrios, aunque el TEDH haya ensanchado el ámbito material de la libertad de expresión (especialmente en relación con personajes públicos), lo bien cierto es que dicha libertad no puede ejercerse de manera desproporcionada (ni siquiera por quienes hacen del periodismo su profesión) frente al honor y a la vida privada (STEDH Rubio Dosamantes c. España de 21 de febrero de 2017).

Se ha reconocido igualmente por el TEDH de manera amplísima la libertad de expresión ejercida por políticos o en una protesta política frente a la reputación del Gobierno (STEDH Castells c. España de 23 de abril de 1992) o contra la dignidad del Jefe del Estado (STEDH Otegi c. España de 15 de marzo de 2011) y/o de la Nación (STEDH Stern Taulats y Roura Capellera c. España de 13 de marzo de 2018), con una proyección llamativamente benévola para los demandantes que a buen seguro puede resultar sorprendente en otros países (en la vecina Francia, pongamos por caso) en donde el respeto a las instituciones y símbolos nacionales se toma en serio sin complejos.

El último caso mencionado, por su carácter reciente y la situación política actual en España (lamentablemente alterada en la normalidad democrática por el desafío secesionista en Cataluña), merece algunas consideraciones. La primera, por empezar con una lectura en clave positiva, que el TEDH está instando a un debate más amplio acerca de la no aplicación de penas de prisión para delitos de opinión o cometidos mediante un ejercicio ilegítimo de la libertad de expresión. En segundo lugar, en contraste, resulta preocupante que el principio de proporcionalidad pueda devenir una especie de mantra (también en la doctrina constitucionalista) para asumir posturas cómoda y falsamente progresistas; me explico: ciertos comentarios doctrinales y algunos medios de comunicación han transmitido la impresión (de mala o buena fe) según la cual el TEDH avalaría simple y llanamente quemar fotos del Rey, en lugar de explicar que la Corte de Estrasburgo no da luz verde a semejante actitud, sino que exige un castigo proporcional (por ejemplo, sanciones pecuniarias) que no implique la privación de libertad (salvo en circunstancias excepcionales —párrafo 34-).

Aun con todo, la STEDH Stern Taulats y Roura Capellera c. España presenta, en mi opinión, menor calado en cuanto al análisis estrictamente dogmático-jurídico del supuesto de hecho que en términos de una discutible laxitud permisiva de la incitación al odio (párrafos 41 y 42), no aceptada por las instancias judiciales internas (mejor situadas para ponderar el preciso contexto, como el propio TEDH ha mantenido reiteradamente acudiendo al ya reseñado margen de apreciación nacional). Desde luego, este otro debate, más profundo, indudablemente tiene que ver con las coordenadas (no exentas de un ostensible adoctrinamiento) en las que se ha desenvuelto en las últimas décadas el sistema educativo en Cataluña, cuya solución lógicamente no está en manos del TEDH, aunque sí puede beneficiarse de la contribución del Consejo de Europa a través de otras instituciones (por ejemplo, el Comisario Europeo de Derechos Humanos).

Con tal espíritu, permítaseme traer a colación el informe elaborado en su día por el Comisario Europeo (a la sazón, Álvaro Gil-Robles) tras su visita a España (y, más precisamente, al País Vasco, del 5 al 8 de febrero de 2001) en donde, entre otros aspectos, 
alertó sobre la necesidad de utilizar «los medios de transmisión de la cultura y del conocimiento para favorecer en los jóvenes y en los niños una concepción legítima de las posiciones nacionalistas», en lugar de favorecer "posiciones racistas o xenófobas», «lo que sin duda es incompatible con una concepción democrática de la sociedad y constituye un germen de violaciones de derechos humanos»; ello lo afirmó tras constatar "por información directa del Consejero de educación del gobierno vasco, esfuerzos y campañas escolares que tienen lugar actualmente para promover valores como la igualdad», pero «habría que estudiar el contenido de algunos libros de texto, que no están precisamente de acuerdo con un objetivo de comprensión mutua y de convivencia, o la erradicación de ciertos programas de la televisión pública vasca, en los cuales se tolera que los niños canten canciones de menosprecio respecto de los españolistas» (CommDH(2001)2 / 09 Marzo 2001, p. 12).

Lo anterior da pie para, concluyendo, añadir una referencia a la jurisprudencia del TEDH con respecto a los delitos de odio, que de algún modo se sintetiza en el citado párrafo 41 de la STEDH Stern Taulats y Roura Capellera c. España (más información en la ficha temática sobre discurso del odio en la web del TEDH; la última versión visitada data de febrero de 2018: https://www.echr.coe.int/Documents/FS_Hate_speech_ENG. pdf). Como línea de principio, resulta plausible que el TEDH entienda que «los discursos incompatibles con los valores proclamados y garantizados por el Convenio quedan sustraídos de la protección del artículo 10 por el artículo 17», es decir, que no quedan amparados por la libertad de expresión del art. $10 \mathrm{CEDH}$, sino que constituyen abuso de derecho y se inscriben en la filosofía del adagio francés (atribuido a Saint-Just) «pas de liberté pour les ennemis de la liberté» recogido en el art. $17 \mathrm{CEDH}$.

En definitiva, en la realidad española actual, además de ese discurso del odio que fue objeto de controversia en el marco de la reiterada STEDH Stern Taulats y Roura Capellera c. España, no debe perderse de vista la jurisprudencia del TEDH que limita e incluso excluye de la protección del art. $10 \mathrm{CEDH}$ (para reconducirlo al art. $17 \mathrm{CEDH}$ ) el discurso de odio racista, xenófobo, antisemita u otras formas de odio basadas en la intolerancia (por ejemplo, contra los sentimientos religiosos, excesivamente banalizados en España en los últimos tiempos a través de actos que revelan mala educación, peor gusto y un desdichado modo de vida guiado por el odio, avalados desgraciadamente por una sesgada utilización jurisdiccional interna de los cánones europeos). El reto de una difusión fidedigna y responsable de la jurisprudencia del TEDH, en esta materia y en general, no es menor para la doctrina constitucionalista.

\section{CARLOS RUIZ MIGUEL}

Como comenté al principio, opino que la jurisprudencia del TEDH sobre libertad de expresión no ha sido del todo afortunada, especialmente respecto a España, pues la misma ha llevado en muchos casos a vaciar de contenido el artículo 20.4 de la Constitución. El artículo 10 del CEDH que garantiza la libertad de expresión incluye en su apartado 2 numerosísimos límites. Es un hecho, sin embargo, que el TEDH ha hecho una lectura expansiva de ese artículo (entre otros, en casos referidos a España y valga de ejemplo de ello la reciente sentencia Stern Taulats y Roura Capellera c. España, de 13 de marzo de 2018 —asuntos 51168/15 y 51186/15-). La amplitud que tiene la libertad de 
expresión en el Derecho Constitucional norteamericano no me parece trasladable a Europa porque los supuestos sociales que dan origen a la sociedad política norteamericana son diferentes. No creo que ayude a construir una democracia el amparar las injurias o los insultos. El hecho de que quien los sufra sea un personaje público no sólo debe ser una causa de justificación de los insultos, sino que muchas veces agrava el efecto de los mismos, pues la licitud del insulto a un personaje público relevante actúa como elemento de legitimación social de los insultos... que luego lógicamente se producen en el ámbito privado.

El tratamiento de la libertad de expresión por el TEDH es, para mí, un «contra-modelo» de lo que deber ser la interpretación jurídica porque en pocos casos, como en éste, las invocaciones a ciertas fórmulas (como la del «margen nacional de apreciación») conducen a resultados opuestos a los proclamados y que, además, no están previstos en la norma. Me atrevería a decir que quizá en ningún otro como en el conjunto de casos sobre este derecho el TEDH invoca tanto ese «margen nacional de apreciación»... para terminar exigiendo un «escrutinio estricto» por el TEDH que supone sustituir sistemáticamente la apreciación nacional sobre el asunto por la del TEDH. La técnica des-normativizadora por excelencia es la de la «ponderación». Ésta opera en el tercer momento del razonamiento del tribunal al examinar los límites a la libertad de expresión. El primer requisito, que en muy pocas ocasiones resulta problemático es que la injerencia esté "prevista por la ley», un punto donde la interpretación puede desplegarse con bastante respeto a la norma. El segundo requisito de la limitación, que tampoco plantea graves dificultades es que la limitación se haga invocando alguno de los «fines legítimos» para ello según el Convenio. Pero es el tercer requisito, el que la medida sea «necesaria en una sociedad democrática». Y es aquí donde, de forma diría que sistemática, tras proclamar la existencia de un «margen nacional de apreciación», el TEDH vacía el mismo al indicar que ello no impide la existencia de un «control europeo» que, lejos de ceñirse a definir el ámbito de ese «margen nacional» lo sustituye al considerar, mayormente la existencia de una «necesidad social apremiante» y la «proporcionalidad» de la medida.

Esto lleva a resultados poco ortodoxos jurídicamente donde buscando una «justicia material» el TEDH retuerce no sólo el texto del Convenio, sino su propia doctrina. Así ocurre en algunos casos donde, tras considerar que el CONTENIDO de una determinada expresión no está protegido por el artículo 10 del Convenio, y que por tanto la misma es antijurídica, tras haber invocado el «margen nacional de apreciación» considera que la SANCIÓN a esa expresión, insisto, antijurídica, es «contraria» al Convenio por ser «desproporcionada». Son varios los casos que pueden ilustrar esta forma de razonar, aunque valga citar como ejemplo el caso Fatullayev contra Azerbayán, de 22 de abril de 2010 o el más reciente Stomakbin contra Rusia, de 9 de mayo de 2018.

Es en este marco en el que podemos examinar la jurisprudencia sobre los «delitos de odio». El TEDH ha considerado que no todas las SANCIONES a los CONTENIDOS ilícitos son conformes al Convenio. Y de esta forma ha estimado que sólo las expresiones ilícitas que incitan a la violencia o al odio étnico son merecedoras de sanciones penales, debiendo sancionarse el resto de expresiones ilícitas por medios civiles o administrativos. Pero ha resultado que una vez sentado que sí podían ser sancionables penalmente, al menos, las expresiones de odio el TEDH ha entrado a juzgar si la «severidad» de la condena nacional era o no «proporcionada» (así en el caso Stomakhin) lo que a mi modesto entender constituye una gravísima extralimitación por parte del TEDH. 


\section{ROSARIO TUR AUSINA}

La configuración del sistema democrático supranacional europeo conlleva, por definición, la generación de una real y efectiva opinión pública libre, generada en una ciudadanía libre pero formada y responsable, y de la que resulte una ponderación adecuada entre el leal comportamiento institucional y ciudadano, y el ejercicio de una libre - pero no ilimitada - crítica. En esta tarea, la misión del TEDH es clave, pues estamos ante uno de los ámbitos más significativos para el progreso democrático europeo, que se sustenta sobre el criterio del respeto y tutela de las minorías, uniendo lo diverso y lo común, y más si cabe en el contexto actual de las redes sociales y de las nuevas tecnologías. Por ello fue relevante, tanto llevar a cabo una férrea defensa de la libertad de expresión, como prever el abuso de derechos y perfilar y luchar contra el discurso del odio, pues solo así se combaten las desigualdades, se tutela la dignidad de las personas, y se pone en valor, precisamente, su propia libertad de expresión en igualdad de condiciones.

De este modo, vino a señalar la Recomendación n. ${ }^{\circ} \mathrm{R}(97) 29$ del Comité de Ministros, que dicho discurso abarca «todas las formas de expresión que propaguen, inciten, promuevan o justifiquen el odio racial, la xenofobia, el antisemitismo u otras formas de odio basadas en la intolerancia, que se manifiestan a través del nacionalismo agresivo y el etnocentrismo, la discriminación y la hostilidad contra las minorías, los inmigrantes o personas de origen inmigrante». Un compromiso que se conjugaría desde los inicios, en la jurisprudencia del TEDH, con la otra parte en conflicto: la idea de que al amparo de la libertad de información y de expresión tan válidas son las informaciones y las ideas inofensivas, indiferentes o amablemente recibidas, como aquellas otras que chocan, ofenden o inquietan al Estado o a una parte de su población. De la democracia forma parte no solo lo que nos une sino también lo que nos hace diversos, pues también la tolerancia, la apertura o el pluralismo se integran en aquella (SSTEDH Handyside, de 27 de diciembre de 1976; Lingeus, de 8 de julio de 1986; Oberchlick, de 23 de mayo de 1991; Thorgeir Thorgeirson, de 25 de junio de 1992; doctrina recepcionada por diversas SSTC 62/1982, 76/1995 y 190/1992).

A partir de las consideraciones anteriores, a nuestro juicio la jurisprudencia europea sobre el tema ha puesto de relieve dos importantes problemáticas de enorme actualidad.

De un lado, su doctrina se ha mostrado rotunda, configurando una especie de isla jurisprudencial en concretos aspectos ligados a algunas experiencias históricas: en particular, los discursos negacionistas del Holocausto, cuya mera proclamación considera un abuso de derecho y una amenaza directa para la democracia que incita, per se, a la violencia y a la alteración del orden público. Un eje argumentativo que resulta difícilmente justificable en atención, precisamente, a la anterior doctrina del Tribunal, más benévola y equilibrada, según la cual se necesita, en otro tipo de discursos, aplicar el test de la proporcionalidad a los efectos de justificar la generación de violencia (Esquivel, «El discurso del odio en la jurisprudencia del Tribunal Europeo de Derechos Humanos», Cuestiones Constitucionales, 2016). El Tribunal pone, pues, excesivo empeño en mostrar que se trata de un episodio especialmente grave, arraigado en los orígenes históricos del Consejo de Europa, pero obviando que otros discursos del odio más actuales también son serios. Y es que, si bien es cierto que este concreto negacionismo ligado a la experiencia alemana puede haber disminuido en número de casos ante el TEDH, no lo es menos que existe una deriva y proliferación de los discursos negacionistas en general, ante los cuales el 
Tribunal podría acabar aplicando aquel mismo estándar, lo que supondría a nuestro juicio una indeseable interpretación automática, excesivamente forzada y ajena a la teoría general de los límites que operan sobre la libertad de expresión en el acervo constitucional europeo.

De otro lado, el segundo aspecto problemático ha sido el de la valoración sobre el tipo de restricciones que, configuradas desde los Estados, son permisibles o necesarias en una sociedad democrática (art. 10.2 del Convenio de Roma). Ello nos introduce en la justificación de medidas represoras, y en el olvido —o no debida atención-, de los instrumentos preventivos. En efecto, ha sido respecto a los denominados delitos de odio, con una regulación polémica en el Código Penal español a través de las reformas de 2015, donde se ha producido un cierto divorcio entre los Tribunales internos y los supranacionales. En concreto, la reciente STEDH Stern Taulats y Roura Capellera, de 13 de marzo de 2018, ejemplifica este contexto de discordancias interpretativas. Una resolución que amparó a los recurrentes por la quema de fotos del Rey, y en la que el TEDH entiende que no hay delito de odio y sí un legítimo ejercicio de la libertad de expresión pues, sostiene, aquello debió ser visto como un acto de rechazo y de insatisfacción, pero también como una crítica política, y no tanto personal, de la institución de la monarquía, insistiendo — desde un eje argumentativo clásico-, en que con ello no se generaron comportamientos violentos ni desórdenes.

$\mathrm{Y}$ es que, en cierto modo, el Tribunal pone en evidencia las restricciones de la libertad de expresión exacerbadas cuando advierte de la exigencia de que las autoridades se contengan en la utilización de la vía penal (parágrafo 33 in fine), llegando al punto de someter incluso a crítica el uso de tipos penales especiales en materia de insulto (como los que se refieren a la Jefatura del Estado en nuestro Código Penal, art. 490). De esta forma el Tribunal centra su hilo argumental, puede que en exceso, en la crítica al sistema represivo. Una crítica no obstante merecida, pues lo cierto es que en la reforma de los arts. 510 y 578 del Código Penal, se introdujo como delito el enaltecimiento, la incitación o la promoción, directa o indirecta, de la discriminación, el odio o la lesión de la dignidad de los grupos o de las personas, pervirtiendo, el sentido del art. 18.1 del mismo Código, para el cual la apología solo es delictiva cuando constituye una incitación directa a cometer un delito (López Garrido, «La desnaturalización del Código de 1995», El Pais, 27 de febrero de 2018). El TEDH se esfuerza, en resumidas cuentas, por evidenciar que la sanción penal es, por definición, absolutamente extraordinaria, está prevista para casos límite, y no disuade en absoluto de la comisión de futuros ilícitos en la materia, poniendo de manifiesto el principio de intervención mínima característico del Derecho penal. Es más, la tendencia represora generalizada o la vis expansiva del derecho penal, generan un estado de inquietud y de violencia social que corre el riesgo de reproducir comportamientos ilegítimos e irrespetuosos, lo que contraviene el objetivo básico de convivencia pacífica de esta organización supranacional. Por otro lado, también insiste el Tribunal, quizá igualmente en exceso, en la diferencia crítica política/crítica personal, mostrando el mayor sacrificio que supone para los sujetos afectados la primera, cuando lo cierto es que ambas críticas tienden a retroalimentarse hasta el punto de que la espiral de la violencia social acaba por difuminar las fronteras entre lo personal y lo político; y ello por no citar el riesgo de que la crítica política desmedida acabe por llevarse por delante muchas víctimas ciudadanas colaterales y la propia convivencia social. 
El Tribunal, en resumidas cuentas, pone el acento en los instrumentos sancionadores, con una atención particular hacia el derecho penal; pero olvida o no presta la suficiente atención - y esta es la segunda cuestión en la que se necesita un cambio de orientación-, a las medidas preventivas. No se trata, pues, de justificar una libertad de expresión sin límites o excesivamente benévola, pero sí de sentar las bases para un pacto constitucional en el que se equilibre un completo aparato normativo y jurisprudencial preventivo/sancionador, con una libertad de expresión sería y crítica, pero también prudente, responsable y formada.

Por todo ello conviene considerar que los episodios anteriores se inscriben, en realidad, en un contexto más amplio. Nuestra libertad de expresión está en jaque y las redes sociales y las nuevas tecnologías han contribuido a ello. En efecto, esta jurisprudencia necesita atender a la compleja cuestión de la producción en red, constante y acelerada, a veces irracional o poco meditada - la era de Internet lo favorece-, de expresiones manifestadas con sátira, crítica, burla, ironía, humillación, falta de respeto,... que, en un efecto contagio desbocado, se reconducen y llegan a perseguirse finalmente, por la necesidad de ser atajadas seriamente, por los tribunales — distanciándose en cierta forma de la jurisprudencia europea-, a través del tipo penal relativo al discurso del odio (el que promueve, incita o fomenta al odio, hostilidad, discriminación o violencia). Incluso actos físicos, como una quema de banderas o de fotos, tienen su correspondiente proyección virtual, pues son amplificados a través de los medios de comunicación y de las nuevas tecnologías, dejando ahora al margen los intereses de las empresas periodísticas y de la ciudadanía que estén o no detrás de esa difusión.

A nadie se le escapa que buena parte del futuro de las democracias estará en la capacidad del sistema constitucional europeo para construir un equilibrio constitucional donde es imprescindible una opinión pública no solo libre, sino formada y respetuosa con la libertad, la igualdad y la justicia. Y ello aunque, como señala la propia jurisprudencia de Estrasburgo, en el ámbito del discurso y del debate político apenas haya margen para las restricciones a la libertad de expresión. Un margen que por cierto no acabamos de entender, pues la crítica no debería estar reñida con la falta de respeto político gratuito ni con la difamación. En cualquier caso, en estas cuestiones el Tribunal de Estrasburgo tiene todavía la oportunidad de sentar unas bases sólidas y rotundas, quizá algo más comprometidas con la otra cara de la moneda: la lucha contra la intolerancia y el discurso del odio más allá de las medidas represivas, desde el ejercicio de una libertad de expresión más responsable y autocrítica. Pero para ello, en efecto, debemos antes tomar conciencia de lo que realmente vivimos.

Se trata de plantearnos, como nos dice Bauman, a cuanto espectáculo de violencia casual, gratuita, e inmotivada — la violencia por la violencia —, estamos cotidianamente expuestos, en una plena banalización del daño que nos sitúa en un contexto de bullyismo social generalizado. Cierto que el discurso del odio viene instalado en las sociedades desde tiempos inmemoriales; pero también es verdad que se ha incrementado exponencialmente, y que es vivido de una forma más intensa, a nuestro juicio, por la suma de dos factores: por el efecto de las nuevas tecnologías, del potencial comunicativo y del mundo online, pero también por la falta de una educación en valores constitucionales. Ante la confluencia de estos dos elementos, este mundo online — señala Leoncini en su diálogo con Bauman-, nos viene a traer la última de las crisis de las democracias, con un importante agravamiento de los conflictos y de las divisiones políticas, sociales e ideológicas. En el 
mundo online — nos dice aquel autor-, a diferencia de lo que ocurre en el mundo offline, la persona es il padrone y tiene el absoluto control, pues se sitúa en su cómoda zona virtual de confort, en sus minutos de gloria, pero donde en realidad cada sujeto permanece aislado, refugiado en sus opiniones que vuelca contra el resto de sujetos e instituciones sin encontrarse nunca cara a cara con su enemigo (Bauman, Leoncini, Nati liquidi. Trasformazioni nel Terzo Millenio, 2017). Este contexto se une, pues, a una falta de cultura generalizada sólida en derechos constitucionales, la cual conlleva por definición lealtad, conocimiento, información y respeto hacia el propio sistema político, de tal modo que incluso la crítica a aquel no puede sino ejercerse a través de los medios adecuados y con la prudencia debida. Por todo ello, y mientras tomamos conciencia de la necesidad de encajar debidamente el mundo online con el offline, conviene darse cuenta de que sin una adecuada formación constitucional y democrática seguiremos cometiendo errores y, seguramente, prescindiendo cada vez más del mundo offline, el cual, al fin y al cabo, permite una interactuación más sólida, en un aprendizaje más humano — social, al fin y al cabo_-, para seguir dialogando y construyendo un pacto constitucional.

En nuestra opinión, solo desde las anteriores premisas puede construirse una jurisprudencia sólida que va por buen camino — de forma excesivamente tímida, no obstante- desde las instancias europeas. Pero se necesita reforzar lo que en realidad esconde la doctrina de Estrasburgo y que a nuestro juicio solo puntualmente evidencia: esa especie de llamada subrepticia sobre el modo en que deben respetarse los derechos apelando a la prevención y llevando a cabo una adecuada delimitación de la frontera entre la represión de una libertad de expresión que supera todo límite, y la prevención o generación de una libertad de expresión respetuosa con el sistema (es conocida la promoción de la Educación en Derechos por parte del Consejo de Europa: Conferencia sobre el futuro de la ciudadanía y la educación para los Derechos Humanos en Europa, Estrasburgo, 20-22 de junio de 2017). A ello parece referirse el Tribunal cuando en el mismo caso Stern Taulats y Roura Capellera c. España señala que «no se puede afirmar que la libertad de expresión en el ámbito de la crítica política sea sin embargo ilimitada. El TEDH recuerda que la tolerancia y el respeto de la igualdad de la dignidad de todos los seres humanos constituyen el fundamento de una sociedad democrática y plural. De ello resulta que en principio se pueda juzgar necesario, en las sociedades democráticas, sancionar, incluso prevenir, todas las formas de expresión que propaguen, inciten, promuevan o justifiquen el odio basado en la intolerancia (incluida la intolerancia religiosa), si se vela por que estas «formalidades», «condiciones», «restricciones» o «sanciones» impuestas sean proporcionales a la finalidad legítima perseguida». Las breves y escasas referencias que realiza el Tribunal a la prevención deberían constituir, sin embargo, un punto central de análisis en su futura jurisprudencia, pues el incluso prevenir, debería sustituirse por un sobretodo prevenir.

Ha de admitirse, en definitiva, que si bien los discursos o las expresiones pueden resultar obviamente inoportunos o molestos, e incluso se distancian de los valores y derechos constitucionales - para lo que se necesitan esas políticas preventivas-, es imprescindible que aquellos discursos sigan siendo amparados por una concepción de la libertad de expresión informada por el pluralismo y la libre crítica, pues en la misma no es relevante solo lo que se dice, sino también el contexto en el que se dice, el cual nos dará la oportunidad de incidir en los cambios culturales necesarios. El humor, la sátira, la insatisfacción con el sistema democrático, e incluso la radicalización de ciertos posicionamientos humanos, deberían alertar a poderes y contrapoderes para reaccionar con los 
medios justos, proporcionales y adecuados. Por ello no puede ni debe reconducirse todo a la prohibición ni a la persecución — civil, y menos penal— de estas conductas, lo cual es un factor de pobreza institucional democrática. Ante estas situaciones de radicalización, protestas, desazón, desafección ciudadana,... ha de quedar bien clara la actitud tolerante y abierta de los poderes públicos, que en absoluto pueden fomentar ni apoyar institucionalmente los discursos del odio y, menos, contribuir a la violencia social por ser ello contrario al marco constitucional de convivencia. Más bien están obligados a desarrollar una conducta proactiva respecto a la igualdad y la libertad real y efectiva. En el fondo, y aunque aún quede mucho camino, late este mensaje en el sistema multinivel europeo que abandera Estrasburgo, ante las peligrosas derivas de algunos Estados.

$$
* * *
$$

TITLE: Academic survey about the European Court of Human Rights

ABSTRACT: In this academic survey a group of Constitutional Law Professors answer some questions about the European Court of Human Rights, its origins and evolution, the main features of its work and its decisions, and its relationship with the national States signatories of the European Convention on Human Rights.

RESUMEN: En esta encuesta un grupo de Catedráticos de Derecho Constitucional contestan un conjunto de preguntas sobre el Tribunal Europeo de Derechos Humanos, su origen y evolución, las principales características de su jurisprudencia, y su relación con los órganos de los Estados firmantes del Convenio Europeo de Derechos Humanos.

KEY WORDS: European Court of Human Rights, European Convention on Human Rights.

Palabras Clave: Tribunal Europeo de Derechos Humanos, Convenio Europeo de Derechos Humanos.

FECHA DE RECEPCIÓN: 29.06.2018 FECHA DE ACEPTACIÓN: 13.09.2018 
